\title{
STRATIGRAPHIC CORRELATION OF THE HETEROGENEOUS CRETACEOUS AGED SEDIMENTS OF THE POTOMAC FORMATION IN NEW CASTLE COUNTY, DELAWARE THROUGH EXAMINATION OF CORE, WELL LOGS, AND PALYNOLOGY
}

by

Michael Fulton

\begin{abstract}
A thesis submitted to the Faculty of the University of Delaware in partial fulfillment of the requirements for the degree of Master of Science in Geology
\end{abstract}

Fall 2018

(C) 2018 Michael Fulton

All Rights Reserved 


\section{STRATIGRAPHIC CORRELATION OF THE HETEROGENEOUS CRETACEOUS AGED SEDIMENTS OF THE POTOMAC FORMATION IN NEW CASTLE COUNTY, DELAWARE THROUGH EXAMINATION OF CORE, WELL LOGS, AND PALYNOLOGY}

by

Michael Fulton

Approved:

Peter McLaughlin Jr., Ph.D.

Professor in charge of thesis on behalf of the Advisory Committee

Approved:

Neil Sturchio, Ph.D.

Chair of the Department of Geological Sciences

Approved:

Estella Atekwana, Ph.D.

Dean of the College of Earth, Ocean, and Environment

Approved:

Douglas J. Doren, Ph.D.

Interim Vice Provost for Graduate and Professional Education 


\section{ACKNOWLEDGMENTS}

I wish to thank my advisors Peter McLaughlin and Ron Martin for constant support and guidance as well as the other member of my committee Jesse Thornburg for his input and knowledge. I would also like to thank the Delaware Geological Survey for providing ample resources to make this project feasible, in particular Charles "Tom" Smith and Paul "Steve" McCreary for their patience and guidance while assisting me conducting strenuous labor, and my friends and colleges including Sierra Davis for constantly supporting me during the grueling application process, as well as my fellow inhabitants of Penny Hall for making this experience as great as it was.

Finally, I must thank my parents, Tom and Terri Fulton, for graciously supporting me in everything I do, and without them none of this would have been possible. 


\section{TABLE OF CONTENTS}

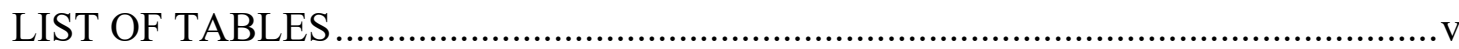

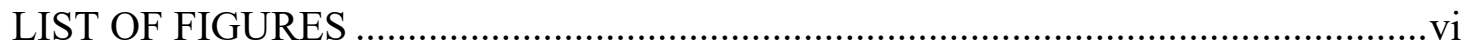

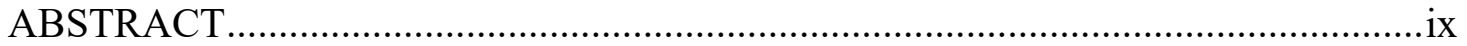

Chapter

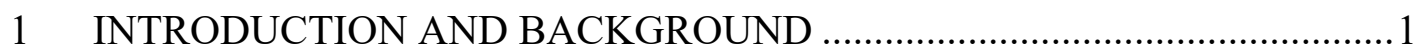

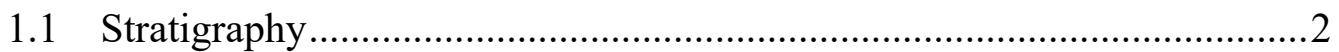

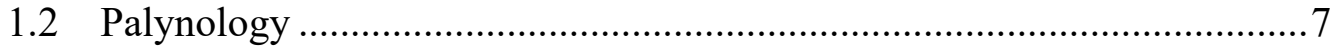

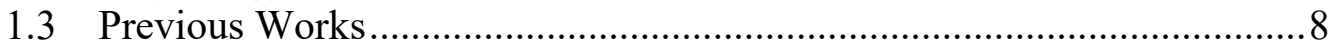

1.3.1 Lithostratigraphy ..................................................................

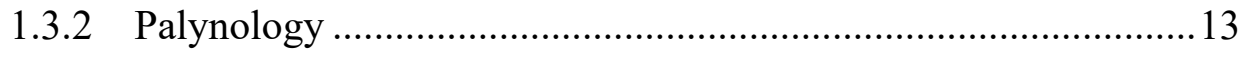

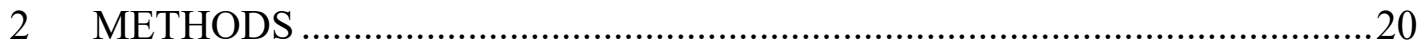

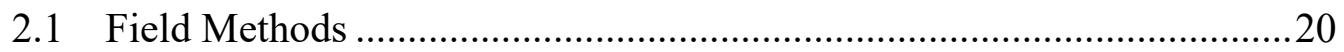

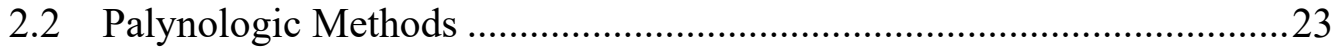

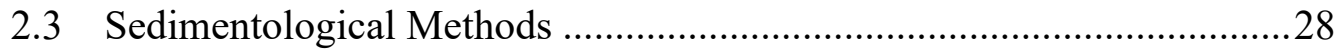

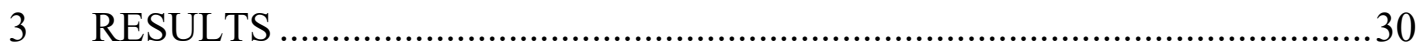

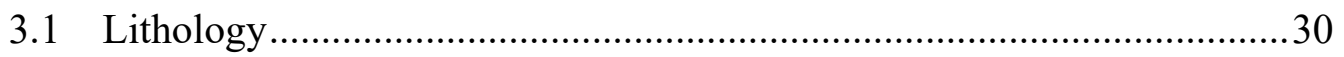

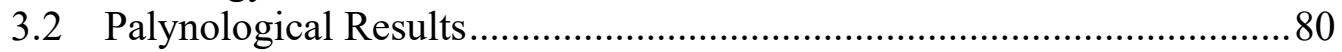

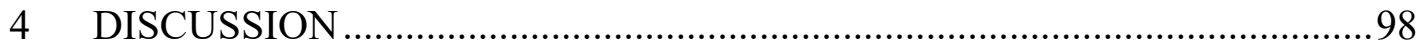

4.1 Lithofacies and Depositional Environments .............................................98

4.2 Cross Section Interpretations: ……………………............................ 111

4.2.1 Overall Lithologic Trends........................................................111

4.2.2 Palynological Trends ............................................................112

4.2.3 Palynofacies and Environments .................................................113

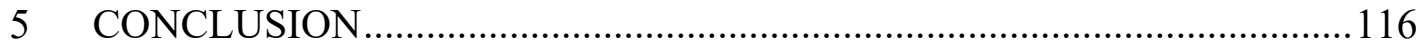

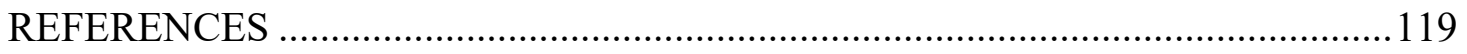

Appendix

A SUPPLEMENTAL MATERIAL ...............................................................125 


\section{LIST OF TABLES}

Table $3.1 \quad$ Bear/Christiana palynomorph counts.....................81

Table 3.2 Glasgow palynomorphs counts..........................86

Table 3.3 Prest Property palynomorph counts........................92 


\section{LIST OF FIGURES}

Figure 1.1 Stratigraphic column of coastal plain units which underlie New Castle County, Delaware (Ramsey, 2005). The Potomac Formation is highlighted by the red box.

Figure 1.2 Cross section of the Atlantic Coastal Plain from northern New Castle County to southern New Castle County. The Potomac Formation is shown in white, thickening down dip. (Benson and McLaughlin, 2006)

Figure 1.3 Sand package distribution within the Potomac Formation. Potomac Formation aquifer sands shown in yellow with black dots. Note the discontinuity of the aquifer sands (McKenna et al, 2004).....

Figure 1.4 Figure depicting the progression which the ages of palynomorphs and zonations have changed through further studies (Hochuli, et al., 2006). 14

Figure 2.1 Map of northern Delaware with red dots indicating the locations of boreholes examined in this study....

Figure 2.2 Formula for obtaining the percentage of indigenous particles observed (University of Minnesota Spiking Documentation Procedure Summary)

Figure 3.1 Stratigraphic log for the Bear/Christiana borehole, including units, geophysical logs, lithofacies, core recovery, formations (including the horizons within the Potomac Formation), and geologic age.

Figure 3.2 Stratigraphic log for the Prest Property borehole, including units, geophysical logs, lithofacies, core recovery, formations (including the horizons within the Potomac Formation), and geologic age.

Figure 3.3 Stratigraphic log for the Glasgow borehole, including units, geophysical logs, lithofacies, core recovery, formations (including the horizons within the Potomac Formation), and geologic age. Figure from McLaughlin, 2012

Figure 3.4 The Dc53-07 borehole is shown here side by side with the geophysical logs, lithofacies, core recovery, formations (including the horizons within the Potomac Formation), and geologic age. 
Figure 3.5 The data for the Ec14-01 Delaware City borehole is shown here side by side with the geophysical logs, lithofacies, core recovery, formations (including the horizons within the Potomac Formation), and geologic age.

Figure 3.6 The data for the Fort Mott borehole is shown here side by side with the geophysical logs, lithofacies, core recovery, formations (including the horizons within the Potomac Formation), and geologic age. Paleosol development indicated by orange (weak) and red (mature).....662

Figure 3.7 The data for the Summit Marina borehole is shown here side by side with the geophysical logs, lithofacies, core recovery, formations (including the horizons within the Potomac Formation), and geologic age. Figure from McLaughlin, 2012.

Figure 3.8 The data for the Cd51-21 New Castle borehole is shown here side by side with the geophysical logs, lithofacies, core recovery, formations (including the horizons within the Potomac Formation), and geologic age. Figure from McLaughlin, 2012

Figure 3.9 The data for the Cd51-23 borehole is shown here side by side with the geophysical logs, lithofacies, core recovery, formations (including the horizons within the Potomac Formation), and geologic age. Figure from McLaughlin, 2012.

Figure 3.10 Map of the study area with the locations of the nine boreholes, and three cross sections in this study.

Figure 3.11 Cross section of the northern most boreholes used in this study. Tops of each unit of the Potomac Formation are highlighted, as well as the depth and interpreted zone of the pollen.

Figure 3.12 Cross section of the southernmost boreholes used in this study. Tops of each unit of the Potomac Formation are highlighted, as well as the depth and interpreted zone of the pollen.

Figure 3.13 Cross section of the boreholes that best represent the down dip trend of the Potomac Formation (for the boreholes used in this study). Tops of each unit of the Potomac Formation are highlighted, as well as the depth and interpreted zone of the pollen.

Figure 3.14 Bear/Christiana palynomorph abundances shown side by side with the lithologic, environmental, and chronologic interpretations 
Figure 3.15 Glasgow palynomorph abundances shown side by side with the lithologic, environmental, and chronologic interpretations.

Lithostratigraphic zones are after Benson (2006).

Figure 3.16 Prest Property palynomorph abundances shown side by side with the lithologic, environmental, and chronologic interpretation

Figure 4.1 Correlation of the interpreted depositional environments of the three newly examined boreholes 


\begin{abstract}
The Potomac Formation in the Middle Atlantic region is an important aquifer to one of the most populated areas in the country. This study integrated palynology with stratigraphic analysis of wireline cores and geophysical logs to understand the distribution of lithologies in the Potomac Formation in New Castle County, Delaware. The aquifer quality sands in this formation were deposited in fluvial channels between muddier interfluvial paleosols and floodplain deposits. As a result, the formation is extremely heterogenous, making it difficult to understand and predict where the aquifer sands are located.

In total, data from nine boreholes was used for this study; six older boreholes and three more recent continuously cored borehole examined for the first time for this research. Due to the heterogeneity of the Potomac Formation, geophysical logs and sediment cores alone do not allow for accurate enough correlation. The palynological analysis provided essential stratigraphic constraints. Five palynological zones/subzones have previously been defined in the Potomac Formation, with accompanying age interpretations, based on the appearance and disappearance of fossil pollen and spores, mostly from angiosperms. The first definitive appearance of the angiosperms is in the Cretaceous Period. Their evolution can be traced through the fossil record in the Potomac Formation, thus making them stratigraphically very useful. The biostratigraphic zones recognized in these cores, combined with the core and well-log lithostratigraphy, can be used to more accurately understand the
\end{abstract}


distribution of sediments. Specifically, the new biostratigraphic data indicate revised stratigraphic correlations within the Potomac Formation in the western part of the northern Delaware Coastal Plain, including the interpreted stratigraphic position of aquifer sands.

The biostratigraphic and lithostratigraphic studies allow the distribution of sediments in the Potomac Formation to be more accurately understood. The lithologic interpretations give insight into aquifer connectivity and can be used to better understand groundwater flow. The new biostratigraphic interpretations increase the extent of subsurface correlations and validate the zone interpretations identified in previous studies. 


\section{Chapter 1}

\section{INTRODUCTION AND BACKGROUND}

The goal of this study was to conduct a thorough stratigraphic correlation of the heterogenous, interfluvial Potomac Formation in northern New Castle County, Delaware. This study utilized micropaleontology, lithostratigraphy, and chronostratigraphy to understand the age, depositional environment, and lithology of the Cretaceous-age sediments the compose the Potomac Formation.

The hypothesis for this study is that by examining sediment, palynomorphs, and well logs, a more accurate correlation of the Potomac Formation can be made throughout New Castle County, Delaware. The Potomac deposits are internally complex with repetition of many similar features that make it difficult to differentiate individual stratigraphic units. Pollen and spores will be used to constrain both the correlation of geophysical logs and core lithologies between three new study sites and six previously examined boreholes in the area. With a greater understanding of the trends and age depth relationship of this formation, the discontinuous aquifer sands found within this formation will be able to be more accurately mapped and understood.

The Potomac Formation extends from the New York City area to the Carolinas. This region has one of the fastest growing populations in the country, with 
a constant demand for fresh water. If demand continues to increase, the deeper aquifer sands of this formation may become an essential resource for fresh water.

Previous studies have analyzed palynomorphs from this formation (and formations of similar age and lithology) to create biozones with ages based off of the evolving angiosperm pollen within the sediments. The Potomac Formation records the expansion of angiosperms in the mid-Cretaceous, so the pollen record of this development has regional, rather than just local, implications. Once a greater understanding of the stratigraphy and palynology of the Potomac Formation has been made through this multidisciplinary project, broader implications can be made about issues such as the environmental and climate controls on aquifer distribution.

\subsection{Stratigraphy}

The Middle Atlantic region is made up of two physiographic provinces: the Atlantic Coastal Plain, and the Appalachian Piedmont, with the boundary between the two provinces is called the fall zone. The Atlantic Coastal Plain lies east of the Appalachian Piedmont, its sediments deposited during the Early to Late Cretaceous (Jordan, 1983). The rocks of the Appalachian Piedmont extend far beyond the fall zone and make up the basement rock for the Atlantic Coastal Plain (Jordan, 1962). The overall trend of the sediments of the Atlantic Coastal Plain are dipping and thickening to the southeast, younger units dipping at slightly less of an angle (Jordan, 1962; Benson and McLaughlin, 2006). The Potomac Formation lies within the Atlantic Coastal Plain and will be the focus of this study. Three units have been 
defined within the Potomac Formation of Delaware, listed here from oldest to youngest: Layer C, Layer B, and Layer A (Benson, 2006).

The Potomac Formation has been interpreted as being composed of five different types of deposits (McKenna et al., 2004). These deposits are amalgamated sand, thick sands, thin sands, interlaminated sand and silt, and mottled silts and clays. These types of deposits support the interpretation of anastomosing river system and braided streams being the environment of deposition for the Potomac Formation. The nature of islands within an anastomosing river system is more stable and still exists when the river reaches nearly bankfull stage (Makaske, 2001). Anastomosing river systems are characterized by extremely stable channel positions that split into subchannels which divide and rejoin on a scale many times larger than the width of the channel. These sub-channels can be either highly sinuous or relatively straight. These types of river systems are common in swamps, marshes, and on delta tops. Highly stable banks are characteristic of anastomosing rivers, the resulting channel sand bodies are commonly in shoestring form, bounded laterally by levee and over bank deposits (Reading, 1986). Braided stream patterns result from a relationship between high sediment supply and lesser amounts of water discharge. High rates of sediment supply overload the system, increase the slope until a balance between transport and supply is achieved (Reading, 1986). Within braided channels, mobile and stable zones of sediments form. In the mobile zones braiding and channel shifting are both frequent and the channel is typically unstable (Church, 1983). A key feature of braided streams is the formation of bars and the downstream migration of these bars. These are 
classified in various ways such as longitudinal, transverse, and bank attached bars (Reading, 1986).

The nature of these deposits is important when attempting to identify trends and patterns within the formation. The environment of deposition is a major factor when determining the lateral connectivity of aquifer quality sand deposits. These differentiations will show broader trends and tendencies within the formation.

The stratigraphy of the Potomac Formation is interpreted differently from state to state. The name was given to what Groot (1955) had interpreted in northern Delaware and Maryland as the "nonmarine Cretaceous sediments". In Maryland, the Potomac was recognized as a Group with the subdivisions Patuxent, Arundel, Patapsco, and Raritan Formations (Clark and Bibbins, 1897) with the later addition of the Waste Gate Formation (Hansen, 1982). The current stratigraphic column of the Atlantic Coastal Plain is shown in Figure 1.1. However, the name Raritan is no longer used in Maryland, pollen and spore assemblages indicate that the Maryland Raritan is likely the uppermost part of the Patapsco (Wolfe and Pakiser, 1971). These subdivisions are largely based on the occurrence of the distinctive Arundel Clay, which is not found northeast of Baltimore County, Maryland and separates the lower sandier Patuxent from the higher sandier Patapsco (Edwards Jr. and Hansen, 1979). Like Delaware, New Jersey recognizes the Potomac as a formation subdivided into three units; Unit I as the oldest, Unit II, and Unit III as the youngest (Owens et al., 1998). These units are however recognized using different terminology than in Delaware. 


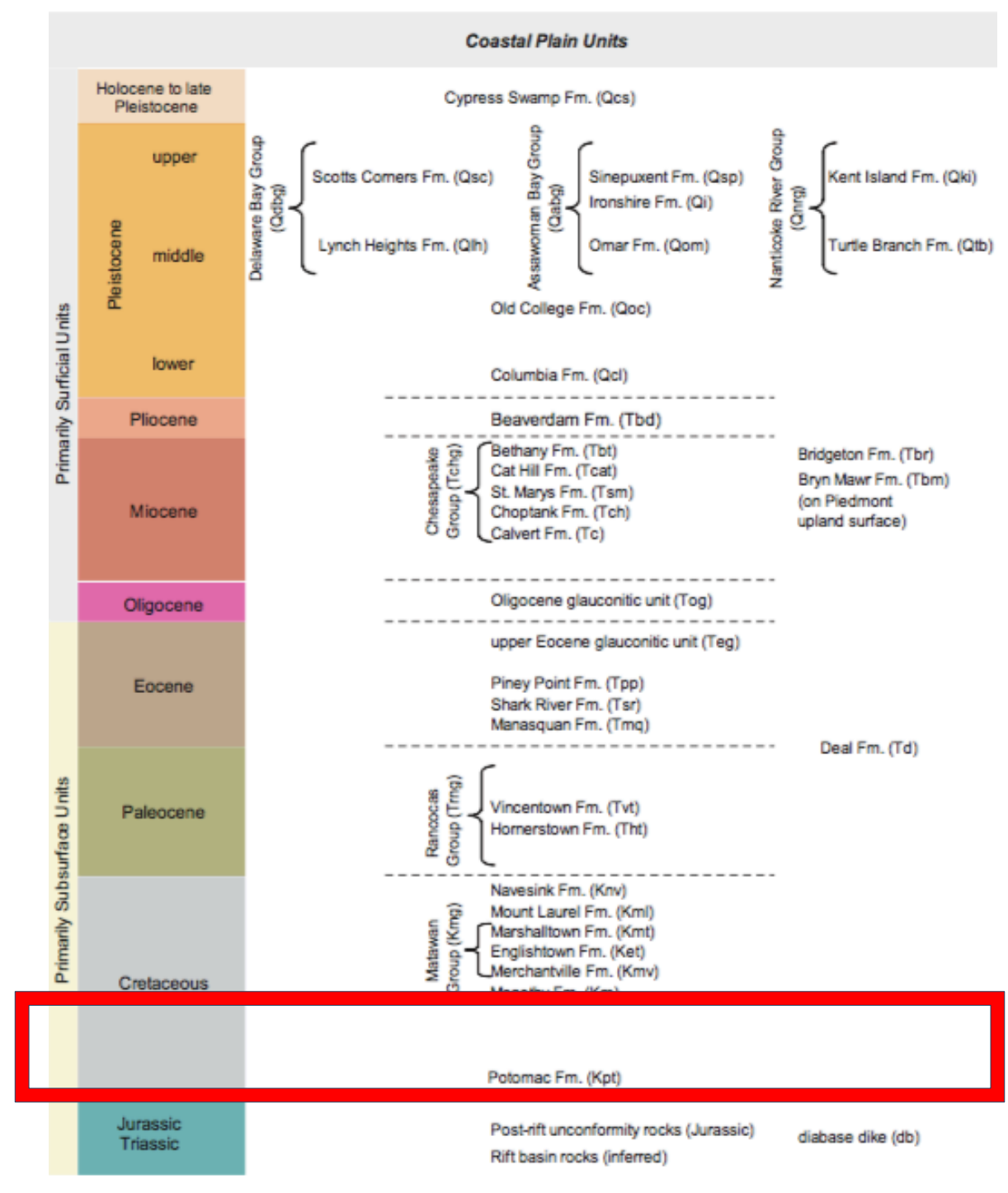

Figure 1.1 Stratigraphic column of coastal plain units which underlie New Castle County, Delaware (Ramsey, 2005). The Potomac Formation is highlighted by the red box. 

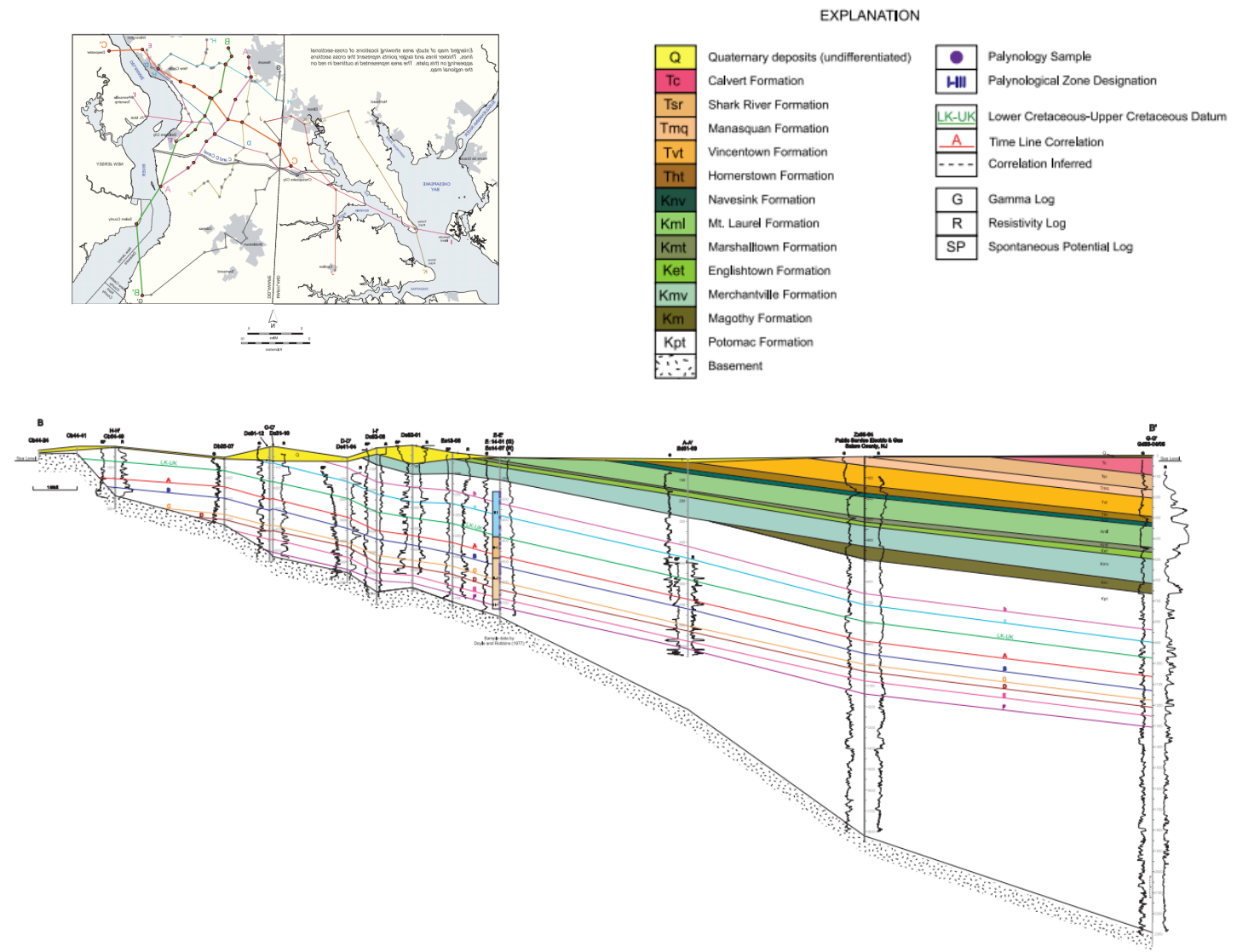

Figure 1.2 Cross section of the Atlantic Coastal Plain from northern New Castle County to southern New Castle County. The Potomac Formation is shown in white, thickening down dip. (Benson and McLaughlin, 2006) 


\subsection{Palynology}

The pollen and spores of the Potomac Formation of the Atlantic Coastal Plain have been of much use for the purpose of age dating and correlating within the formation. This fluvial deltaic sequence lacks sufficient lithological and macropaleontological criteria for an accurate subdivision and correlation using only those parameters (Doyle and Robbins, 1977). The pollen found in this formation provides a nearly continuous record of the rise of angiosperms. By observing the first appearance of new species, as well as the changes in the abundances of certain palynomorphs, a better correlation can be made throughout the study area. The results of a palynological analysis will provide a basis for important biostratigraphic constraints to evaluate the current stratigraphic framework. Through an improved understanding of the stratigraphic framework, a more detailed depiction of the aquifer geometry in these difficult to correlate non-marine facies can be made.

The oldest known unambiguous angiosperm fossils of North America, dated between 125 and 115 million years old, can be found within the Potomac Group at the Dutch Gap in Virginia (Jud and Hickey, 2001). The oldest known widely accepted angiosperm pollen is rare monocolpates (Clavatipollenites) that are Valanginian in age, and only found in regions of low to midlatitude (Gubeli et al. 1984; Hughes and McDougall, 1987; Hughes, 1994). Throughout the rest of the Cretaceous period 
angiosperms were consistently evolving and becoming more abundant within the landscape of the Atlantic Coastal Plain (Doyle, 1969).

\subsection{Previous Works}

\subsubsection{Lithostratigraphy}

McKenna et al. (2004) made lithologic interpretations for the Potomac

Formation using cores and geophysical logs obtained from within New Castle County, Delaware. In their study McKenna et al. (2004) interpreted that the Potomac Formation is composed of five lithofacies. These lithofacies are the basis for the lithologic and environmental interpretations made in this study. The five lithofacies are described in further detail by McKenna et al. (2004).

Amalgamated channels are large sand deposits (30-70 ft thick) of mostly medium to fine sand. These packages have high lateral connectivity and make for good aquifers.

Isolated channels appear as thick sand packages. These deposits are typically 5-20 ft thick with a fining upward pattern. These deposits have poor lateral connectivity, making for less ideal aquifers than amalgamated channels.

Crevasse splay/ proximal levee deposits are identified as thin sand deposits. Mud clasts and charcoal are abundant in these deposits. Silt and clays within the deposits can act as aquitards, creating local aquifers. 
Distal levee/ flood plain deposits appeared as interlaminated sand and silt. These layers are centimeter scale with alterations between the amount of sand and silt. These deposits can act as aquitard, but do not often make for quality aquifers.

Weathered flood plain with paleosols deposits are represented by mottled silts and clays. These deposits are important aquitards, any sandy lithologies commonly contain a significant component of silt or clay. These layers exhibit extensive mottling or irregular banding.

In 2012, the first 2D seismic study, understanding the fluvial channel geometry and dimensions of the Potomac Formation was conducted by Zullo (2012). The result of this study was a two-dimensional basis for understanding the dimensions and distribution of the various lithofacies that make up the Potomac Formation. This study showed the poor connectivity of the sand bodies that make up the aquifers of the Potomac Formation. Throughout the three intervals of the Potomac Formation, Zullo (2012) observed that each interval contained a different ratio of fluvial channel sands that are useful aquifer packages and muddy paleosols. The sand to paleosol ratios throughout the formation were observed as follows: the upper section of the Potomac with a 1:2.5 sand to paleosol ratio, the middle interval with a 1:3 sand to paleosol ratio, and the lower most interval with a 1:2 sand to paleosol ratio. The sand bodies of the Potomac were observed, using seismic interpretation, as highly discontinuous with low lateral and vertical connectivity (27\%). The seismic also indicated that the sand bodies were less extensive than previously interpreted and have poor connectivity. Because of the very heterogeneous distribution of facies, a thorough biostratigraphic 
understanding is needed in order to obtain an accurate broad correlation within this formation. Regardless of geometry of the sand bodies, the biostratigraphy will be useful in more accurately interpreting age of the correlatable intervals of the Potomac Formation. This information stresses the need for a greater biostratigraphic understanding of the formation in order to maximize the use of the fluvial channel sands when prospecting locations of potential aquifers.

The first thorough analysis of the paleosols of the Potomac Formation was conducted by Thornburg (2016). He conducted research into the environments of soil formation based on the composition and color of the paleosol unit at each depth. His research also attempted the correlation between three sites in New Jersey and Delaware based on spores and pollen. His work created a basis for the understanding of the environment of formation for these paleosols based on color and chemical composition. He was able to understand water table levels and make inferences on how climate changed in the Cretaceous from these paleosols. The classification of paleosol environments made by Thornburg (2016) will be used to make the best attempt of understanding the environment and degree of maturation of the paleosols observed.

Thornburg interpreted paleolandscapes at three different locations based on the lithologies and paleosols features. These three locations were Fort Mott, New Jersey; Medford, New Jersey; and Summit Marina, Delaware. Unit I at Fort Mott was interpreted as an anastomosing river system. At Medford, no paleosols were preserved in Unit I and the landscape was interpreted as a braided fluvial system. In Unit II at all 
three sites, paleosols were preserved. The base of Unit II is dominated by fluvial sands and interpreted as an anastomosing river system. Up section, the paleosols show fluctuating conditions between reduced and enhanced drainage. Unit III contains a large package of sand, found in all three sites. This unit is also interpreted as an anastomosing river system; however, there is an up section change in sand thickness and heterogeneity which was interpreted as the result of fluctuating base level conditions and an increase in the avulsion frequency of the anastomosing fluvial system. 

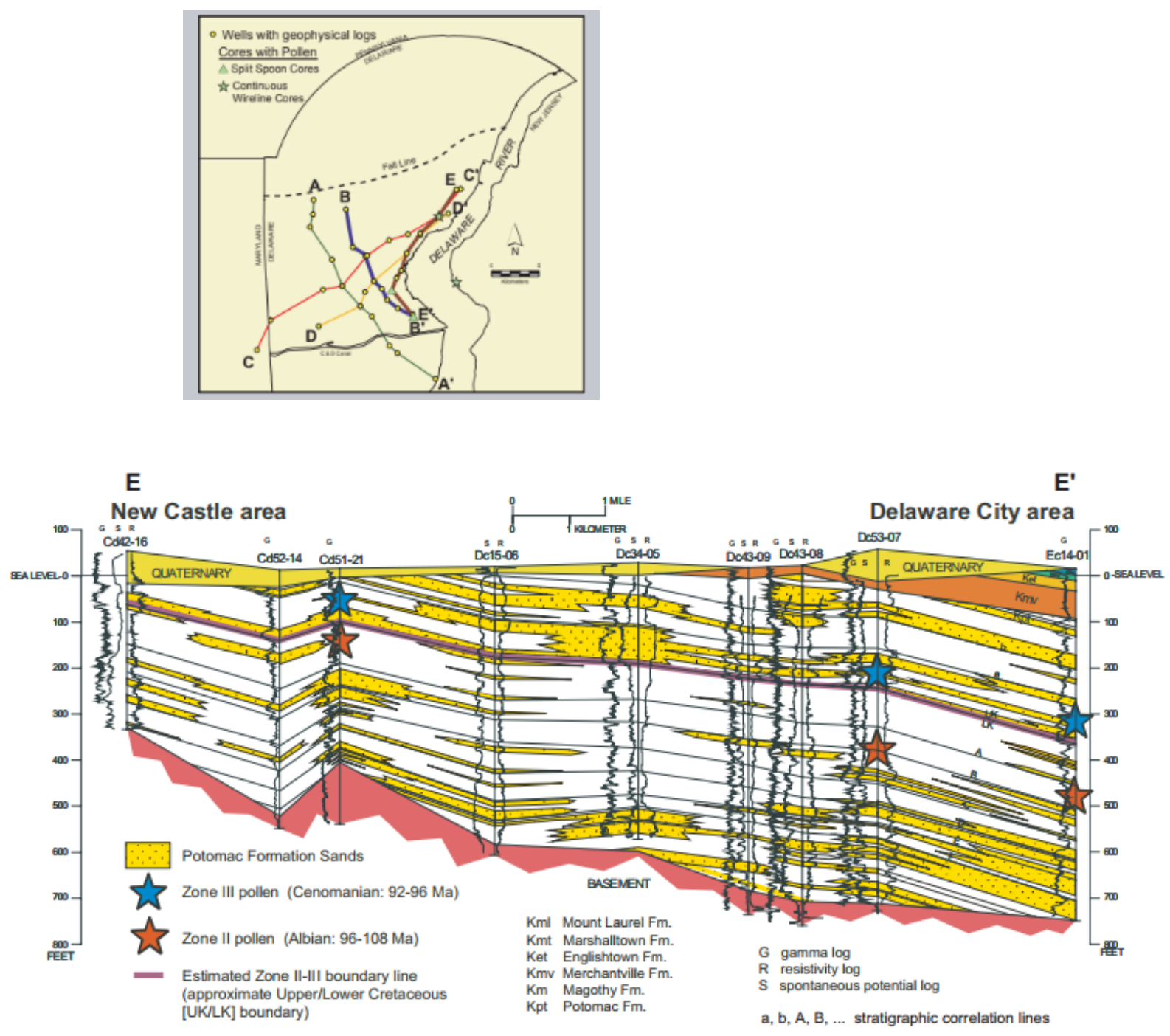

Figure 1.3 Sand package distribution within the Potomac Formation. Potomac Formation aquifer sands shown in yellow with black dots. Note the discontinuity of the aquifer sands (McKenna et al, 2004) 


\subsubsection{Palynology}

Palynology has played an important role in previous studies to age date and map this formation. Palynological zonations for Cretaceous-aged sediments were first made by Brenner (1963) using samples obtained in Maryland. Doyle and Robbins (1977) were then able to create further zonations of pollen from the Cretaceous using sediment obtained from three wells in northern Delaware. The ages of the zonations defined in their work was further refined by Hochuli et al. (2006) based on their distribution in better-dated stratigraphic sections of western Portugal. The most recent Hochuli et al. (2006) refined zonation, to which this study refers for ages of palynomorph zones, is found in Figure 1.4. Figure 1.4 shows the evolution of the palynostratigraphy of the Potomac Formation over the last few decades. This shows the importance of new palynological data and the impact it has had in the refining of the age of the Potomac Formation. 


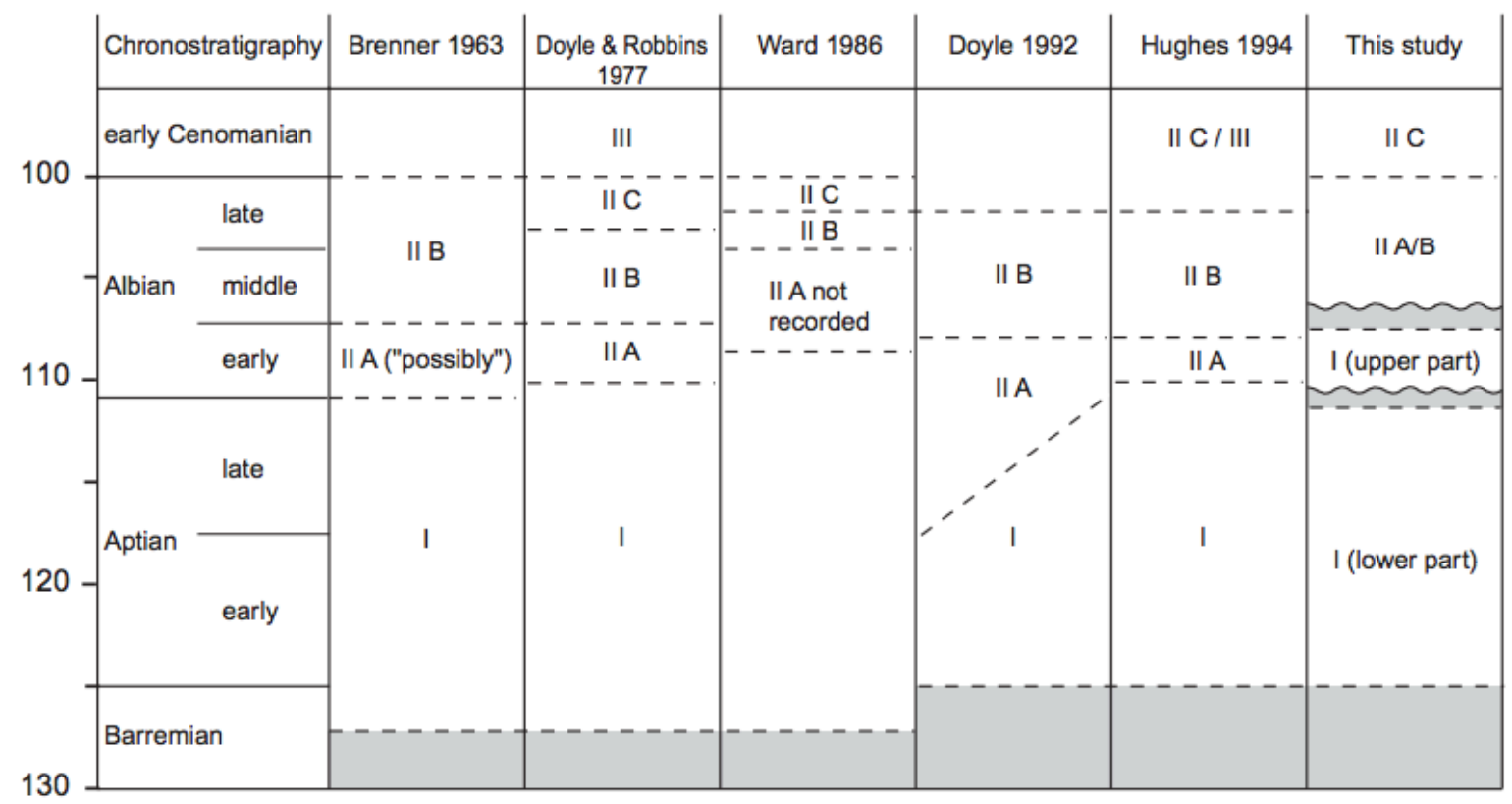

Figure 1.4 Figure depicting the progression which the ages of palynomorphs and zonations have changed through further studies (Hochuli, et al., 2006). 
The first attempt at a complete catalog of the spores and pollen of the Potomac Formation was conducted by Brenner (1963) where he described 102 different taxa. Using mainly spores, Brenner recognized two zones within the palynomorph assemblage, Zone I and Zone II, with Subzones A and B within Zone II. Subzone II-B was further subdivided into B-1 and B-2. These subdivisions were based primarily on ranges of index species and secondarily on vertical frequency changes. Based on European flora, Brenner (1963) believed the Potomac Formation to be of upper Barremian to upper Albian in age.

Doyle and Robbins (1977) built on Brenner's work establishing three new zones within the Potomac, five zones in total. The Subzone II-C (which was what Brenner had referred to as the upper part of II-B) as well as Zone III, Zone IV, and Zone $\mathrm{V}$ were added. These zones correspond to the appearance of, and initial growth and distribution of, more advanced major classes of angiosperm pollen. Focusing on angiosperm pollen rather than spores, as Brenner did, allows for interpreting due to the rapid evolution of the angiosperms during the Cretaceous.

The chronostratigraphy of Zones I and II has since been updated and refined by Hochuli et al. (2006), based on comparing the Potomac to well-dated European zones. Hochuli et al. (2006) contributed to this research by comparing the results of two welldated palynological sections from southern Portugal with the work conducted by Brenner (1963) and Doyle \& Robbins (1977). The palynomorphs studied from 
southern Portugal bear many similarities to the Potomac Formation palynomorphs and corresponded chronologically. Hochuli et al. (2016) used not only the first appearance of some pollen groups but also the comparison of diversity and abundance between monocolpate and poly-(tri)-aperturate forms (eudicots). As a second independent approach to dating the subzones IIA, IIB, and IIC, ranges of characteristic species of each subzone were compared with dated records from circum-North Atlantic locations.

Zone I is defined partially by the first appearance of monosulcates. Only a few species are restricted to Zone I. Zone I can therefore before distinguished from Zone II by the absence of these "index species" that are representative of Zone II, and the greater abundance of other species (Cyathidites, Classopollis, and Exesipollenites) (Brenner, 1963; Doyle and Robbins, 1977). The base of Zone I was originally interpreted as Barremian age (Brenner, 1963; Doyle, 1969), with the top of Zone I possibly early Albian aged (Doyle and Robbins, 1977). Hochuli et al. (2006) has more recently interpreted the upper part of Zone I as early Albian, based on assemblages from Portugal.

Subzone II-A is defined by the appearance of the spore Apiculatisporis babsae and the pollen "Monosulcites" chaloneri, Perotriletes pannuceus, new reticulate tricolpates, and other less common non-angiosperm index species (Brenner, 1963; Doyle and Robbins, 1977). Subzone II-A was tentatively dated near the early-middle Albian boundary based on the appearance of the spore Apiculatisporis babsae and 
small reticulate tricolpates found in England (Doyle and Robbins, 1977). Hochuli et al. (2006) has since interpreted Subzone II-A as mid Albian.

Subzone II-B is defined primarily by the appearance of the spores Cicatricosisporites patapscoensis, C. subrotundus, "Lycopodiumsporites” cerniidites (Camarozonosporites), Neoraistrickia robusta, Reticulatisporites arcuates, and other less common index species (Brenner, 1963). The increased occurrence of tricolporoidate tendencies of tricolpate angiosperm pollen species is indicative of Subzone II-B (Doyle and Robbins, 1977). Subzone II-B has tentatively been correlated to be middle to late Albian age (Doyle and Robbins, 1977). Hochuli et al. (2006) has since interpreted Subzone II-B as late Albian.

Subzone II-C is one of the new zones added to Brenner's (1963) zonations, by Doyle and Robbins (1977). Many of the same species from Subzone II-B can be found in Subzone II-C, but the appearance of multiple tricolporoidates and Rugubivesiculites rugosus, and the drastic decline or disappearance of many characteristic Subzone II-B species marks this transition (Doyle and Robbins, 1977). Subzone II-C had been dated as the latest Albian based on comparisons to similar floras observed in England (Doyle and Robbins, 1977). In a more recent study Hochuli et al. (2006) has dated Subzone II-C as early Cenomanian.

Zone III is defined by the appearance of large, triangular tricolporates. It has provisionally been dated as early Cenomanian, compared to flora in North America and Europe (Doyle and Robbins, 1977). Multiple tricolpates appear to reach their typical morphology at or near the base of Zone III (Doyle and Robbins, 1977). 
Zone IV and Zone V were described from younger strata that are not expected to be seen in the Potomac Formation of northern Delaware. Zone IV is defined by the appearance of triporate Normapolles pollen. This zone is not as well established as the others, but it can be recognized on the basis of several new angiosperms. The base of Zone IV has been dated as middle Cenomanian and the top of the zone as early Turonian (Doyle and Robbins, 1977). Zone V is distinguished by the appearance of several tricolporate and triporate taxa not previously seen in Zone IV. Zone V has also been tentatively dated as post-early Turonian to pre-late Santonian (Doyle and Robbins, 1977).

McLaughlin (in Benson and McLaughlin, 2006) described the spore and pollen assemblages in 14 samples from seven different sites in New Castle County, Delaware for biostratigraphic analysis while extending pollen zonations across northern Delaware.

Six of the nine wells used in this study for correlation had been previously examined. Palynomorph zonations for two wells in Delaware City, Delaware (Dc5107, and Ec14-01) had been made by during the Doyle \& Robbins (1977) study. The Fort Mott borehole (Dd42-04) was obtained through the Ocean Drilling Program (ODP), New Jersey Coastal Plain Drilling Project, Leg 174AX in 2001. Palynomorph analysis, and zonations for Fort Mott had been conducted by Brenner and McLaughlin (Miller, et al., 2007). Two wells in New Castle, Delaware (Cd51-21 and Cd51-23) had palynomorph analysis conducted on them by McLaughlin (Benson and McLaughlin, 
2006). The borehole for Summit Marina (Eb33-57) had been processed by Thornburg (2016). 


\section{Chapter 2}

\section{METHODS}

\subsection{Field Methods}

This study will utilize core sample material and palynological data from three borehole sites and geophysical logs from nine borehole sites in the Coastal Plain of northern New Castle County, Delaware. Two sites were drilled before this project began: a 713-ft-deep borehole from the Prest Property near Red Lion, Delaware (39 $35^{\prime} 41.4^{\prime \prime} \mathrm{N} 75^{\circ} 40^{\prime} 36.1^{\prime \prime} \mathrm{W}$ ) on July 25 thru August 8, 2016; and a 250-ft-deep

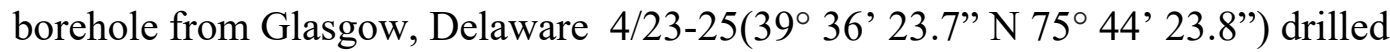
between April 23 and 25, 2012. A new borehole was drilled for this project to $370 \mathrm{ft}$ depth at the DelDOT yard on Bear-Christiana Road near Christiana (39 39' 26.6"N 75³9' 33.9" W) drilled August 14 thru 18, 2017.

Data were used from six other sites for which the core was not examined. This includes two wireline-cored boreholes from New Castle, Cd51-21 (39 40’ 04.5” N

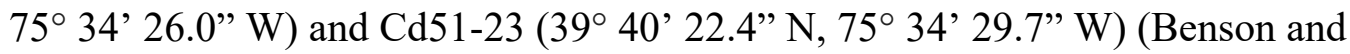
McLaughlin, 2006); a wireline cored borehole at Fort Mott State Park (39 36' 20.4”' N, 75³3'06.7” W) (Sugarman et al., 2004); a wireline cored borehole at Summit Marina (39 $\left.32^{\prime} 42.3^{\prime \prime} \mathrm{N}, 7^{\circ} 42^{\prime} 16.8^{\prime \prime}\right)$ (Thornburg, 2016); and two test wells with scattered split spoon samples from Delaware City, Dc53-07 (39 $35^{\circ}$ 51.8' $\mathrm{N}, 7^{\circ} 37^{\prime}$ 50.1” W) and Ec14-01 (39 34' 23.7” N, 75³6’17.4” W) (Doyle and Robbins, 1977). Lithologic interpretations, palynological data, and geophysical logs were available for all six wells, actual core was not available for examination. 


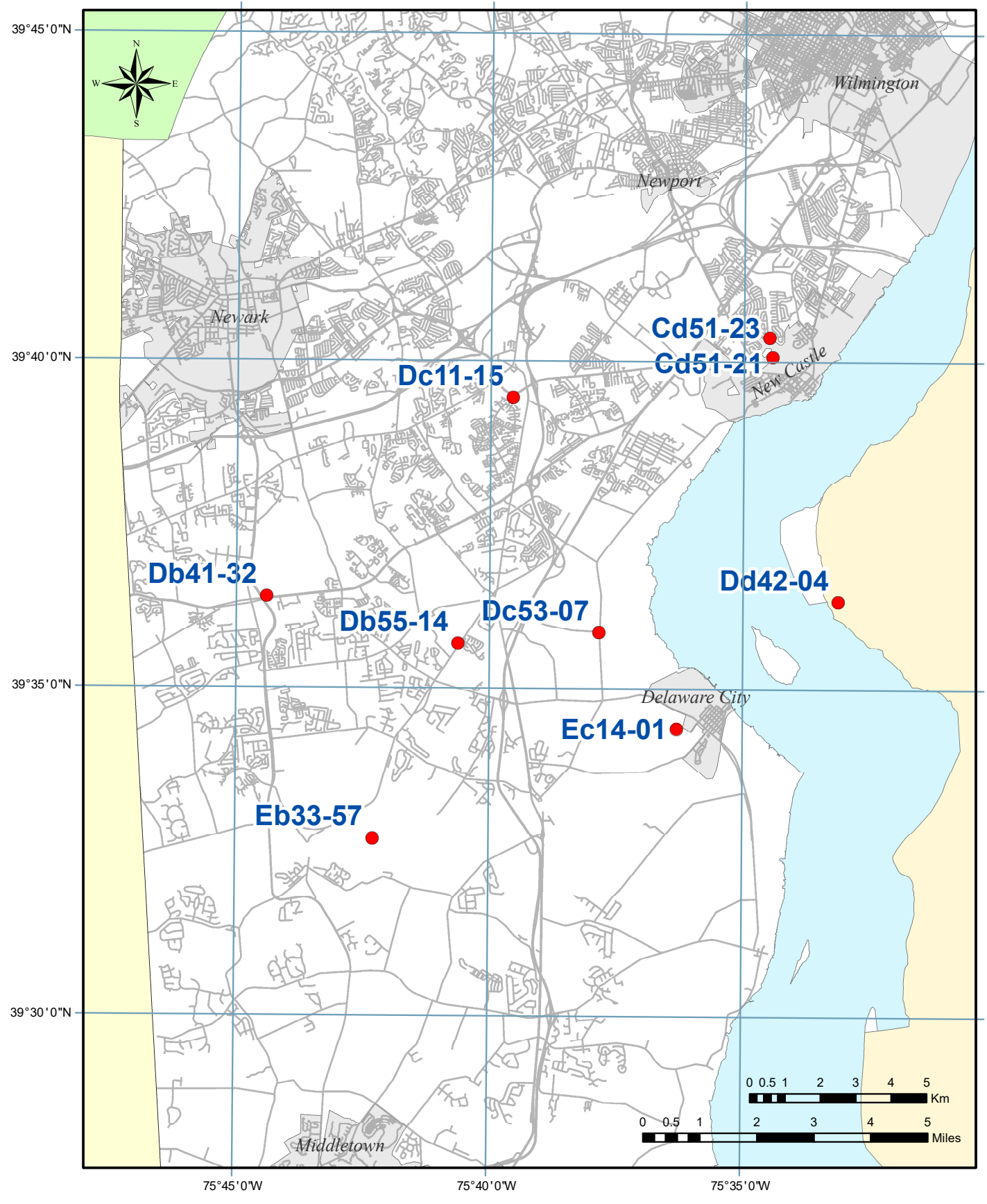

Figure 2.1 Map of northern Delaware with red dots indicating the locations of boreholes examined in this study. 
These three locations were selected based upon site availability. They are all on public property and allow the drill rig to operate far enough away from any residential areas to not be a noise nuisance. Each site does represent a different section of the Potomac Formation, Prest Property being down dip, Bear/Christiana updip and east, Glasgow mid dip and west.

The cores were extracted using standard drilling procedures implemented by the Delaware Geologic Survey (DGS). Drilling was conducted using the CME-55 mobile drill rig owned and operated by the DGS, and an HQ coring system. A 2.5inch-diameter core was obtained, normally in five or ten-foot-long intervals; the exact core length was dependent upon the drilling conditions of the formation. The rig was equipped with a rock coring drill bit, along with a core catching plastic cone inside the coring tube to secure the core sample while bringing the core sample to the surface. Once the core sample has been removed from the coring tube by either a push rod or hydraulic pressure if necessary, it is immediately rinsed and scraped of any drilling mud and analyzed on site.

Onsite analysis consisted of preliminary lithologic interpretations, and texture (including grain size, roundness, and shape), color description using the Munsell chart, fossil interpretations, and any environmental interpretations that can be made. Cores were then placed in two-foot-long PVC pipe cut in half, photographed, and packaged for preservation. All cores are stored in the basement of the DGS Building and are available for analysis. 
Wireline logging equipment were run down the hole to obtain measurements of gamma, resistivity, and spontaneous potential. These logs are used for lithologic interpretations and interpretations on fluid content and salinity.

\subsection{Palynologic Methods}

The process of obtaining palynomorph samples from sediment core involves many steps to get from raw material to samples on microscope slides. Weighed samples are processed using standard palynomorph processing techniques, slides made and examined in microscope, and taxa identified and pollen groups counted.

The material was subsampled every five to ten feet for palynological analysis. Actual intervals were dependent upon the lithology of the cores. Sections of the core made up of gray silts and gray clays were subsampled because these are the only lithologies in which palynomorphs are preserved in high enough frequency for an accurate and thorough interpretation. Taking all of the subsamples from the core at the same time helps to limit exposure and contamination. In total, 42 samples were taken to be processed for palynological analysis; 9 from Bear/Christiana, 18 from Glasgow Park, and 15 from Prest Property. Of those 42 samples, 25 yielded enough pollen to allow proper analysis; 10 from Glasgow Park, 9 from Prest Property, 6 from Bear/Christiana.

At least 30 grams of sediment was the desired amount for each sample. Quarter or half sections of the cylindrical core in $0.1 \mathrm{ft}$ intervals were carefully removed and placed in labeled, sealed, plastic bags. Place cards were left at each interval containing 
information on depth, date taken, purpose, and who had conducted the extraction. The samples were then placed in beakers and left to dry in a $60^{\circ} \mathrm{C}$ oven. Once dry, the sample was placed in a plastic bottle and weighed. The weight of the empty plastic bottle was recorded and subtracted from the total, thus calculating the dry sample weight.

A sample spike was then added. This was accomplished by adding a known volume of polystyrene microspheres to the dry sample. These microspheres are resistant to chemical processing. One milliliter of a previously prepared sample spike solution, containing these microspheres, was added to each sample. A hemocytometer count was conducted on the sample solution to determine the known number of microspheres that were being added. Sixteen hemocytometer counts were conducted with an average 11.3889 microspheres per count, with a standard deviation of 3.8227 . Based on the average microspheres per count, the approximate number of microspheres per $\mathrm{ml}$ was determined to be 113,889 . By calculating the number of these known added particles, the formula in Figure 2 can be used to determine the number of indigenous particles, which in this study are palynomorphs. 


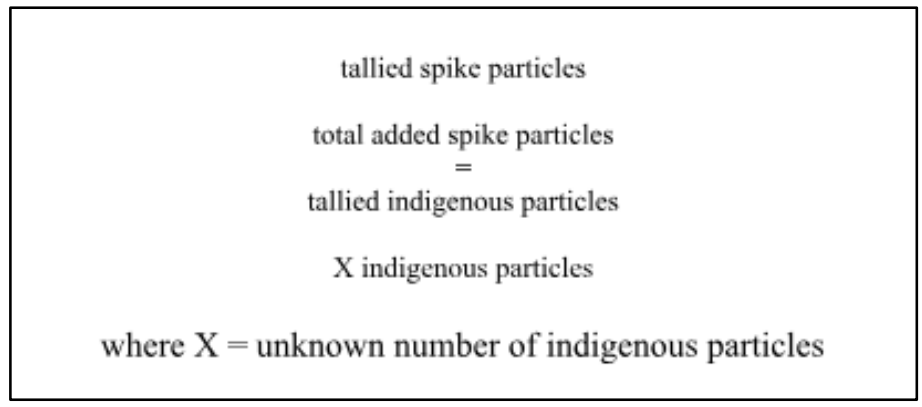

Figure 2.2 Formula for obtaining the percentage of indigenous particles observed (University of Minnesota Spiking Documentation Procedure Summary)

Using this total number of palynomorphs, it was determined what percentage of the palynomorphs in the sample were actually observed while conducting this study. The plastic bottles, at this point containing the spiked samples, were filled half way with distilled water and stirred.

Extraneous mineral and organic matter must be removed from the sample before observations can be made. Carbonates were removed using 37\% hydrochloric acid $(\mathrm{HCl})$. Excess water was poured off and enough $\mathrm{HCl}$ was added to each bottle to fully submerge the sample, and then mixed. Each sample was centrifuged, decanted, and washed with distilled water. This was repeated until neutral.

Siliciclastic sands were removed from the sample by rinsing and swirling the wet sample and retaining the fine fraction that is poured off. This process was repeated to remove as much of the sand as possible, but not all could be removed by this step alone. 
Remaining material was treated with $48 \%$ hydrofluoric acid (HF) and left for several days to demineralize the silicate content, and then rinsed with $20 \% \mathrm{HCl}$, then neutralized with distilled water. Samples were transferred to $50 \mathrm{ml}$ polypropylene vials for further treatments.

A $35 \%$ nitric acid $\left(\mathrm{HNO}_{3}\right)$ oxidation treatment was performed next. Each sample was treated with $\mathrm{HNO}_{3}$ for 5 minutes. The vials were then filled the rest of the way with distilled water, centrifuged, and the supernatant decanted. This process was repeated until neutral.

Next, a 5\% ammonium hydroxide $\left(\mathrm{NH}_{4} \mathrm{OH}\right)$ treatment was applied to the sample for 5 minutes for the removal of humic acid. The vials were once again washed with distilled water and centrifuged until neutral.

The sample was then treated with acetic acid $\left(\mathrm{C}_{2} \mathrm{H}_{4} \mathrm{O}_{2}\right)$ for dehydration, then centrifuged and decanted in preparation for acetolysis. Acetolysis was conducted on the palynomorphs using a mixture of acetic anhydride $\left(\mathrm{C}_{2} \mathrm{H}_{4} \mathrm{O}_{2}\right)$ and sulfuric acid $\left(\mathrm{H}_{2} \mathrm{SO}_{4}\right)$. The samples were placed in a boiling water bath for 5 minutes, centrifuged and decanted. This process makes the fossil pollen grains expand, which can enhance the sculpture for improved analysis. To conclude acetolysis, the sample was treated with acetic acid once again, then washed and centrifuged until neutral.

Gravity separation occurs by adding this heavy liquid to the solution and thoroughly mixing. $\mathrm{ZnCl}_{2}$ has a specific gravity of 2.0 at $25^{\circ} \mathrm{C}$, the sample used in this study had a specific gravity of 2.91 . The sample was then centrifuged; first at 500 RPM for 20 minutes, then at 1500 RPM for 10 minutes. The mineral grains heavier 
than the liquid (zinc chloride) sink, while the organic matter floats. The floating organic matter was then removed using a pipette and placed in a $15 \mathrm{ml}$ tube. Each sample was then treated with $2 \% \mathrm{HCl}$, centrifuged, and washed with distilled water until neutral. The zinc chloride treatment was repeated on samples in which the heavy mineral matter did not adequately separate from the organic. Repeating this step decreased the amount of excess mineral matter and improved resolution when later analyzing the sample for palynomorphs.

Each sample was stained red with sarafin dye for improved observation. One to three drops were added to each sample, number varying based on the amount of sample in each tube. Tubes with what was determined to be "a lot" of sample matter were given two or three drops. Tubes with only a thin line of organic sample matter were given one drop. Tubes were then filled with distilled water, centrifuged, and decanted. The sample was then rinsed with ethanol to allow the stain to set, centrifuged and decanted. Distilled water was then added to the remaining sample until a desired visual concentration was reached.

Each sample was double mounted on a 1 inch by 3 inch slide. One drop of PVA (polyvinyl acetates) glue was placed on a coverslip (located on a slide warmer), followed immediately by a few drops of sample. The solution was spread evenly across the coverslip until dry. Two drops of Norland Optical Adhesive 65 were placed on a clean, labeled slide roughly one inch apart. The coverslips were gently placed on top of the optical adhesive, then exposed to UV light until completely dry (about 10 to 15 minutes). 
Palynomorphs were identified using an Olympus $\mathrm{CH}-2$ compound microscope. Slides were examined at 400x magnification, and 1000x magnification with oil immersion when closer examination was necessary. Relative abundances were determined based on counts of 100 palynomorphs per sample. Scanning of the slides was conducted in an evenly spaced grid pattern alternating from top of the slide to bottom gradually moving towards the center. This is standard practice for assuring an accurate depiction of the relative abundances of the species present, due to the possibility of uneven distribution.

\subsection{Sedimentological Methods}

A multidisciplinary sedimentological analysis was conducted using cores, photos of cores, on site interpretations, and well logs. Sedimentological characteristics observed using all of the previously stated data sets were the basis in which facies interpretations were made. The Potomac facies interpretation work by McKenna et al. (2004) had characterized the Potomac Formation into being composed of five different lithofacies with associated depositional environments. These five depositional environments were interpreted in each section of the Potomac Formation in the Prest Property and Bear/Christiana wells, which were not previously studied.

Data sets from seven previously studied wells were used for correlation of this new data. New chronostratigraphic, lithostratigraphic, and biostratigraphic interpretations needed to be made for many of these seven wells, for purposes of this study. These new interpretations were made using the available data consisting of 
cores, well logs, and reports. The data of the previous studies was combined with the results from this study allowing for accurate broader correlations to be made. 


\section{Chapter 3}

\section{RESULTS}

\subsection{Lithology}

A lithologic analysis was performed on each of the sites used in this study:

Bear/Christiana (Dc11-15), Prest Property (Db55-14), Glasgow (Db41-32), Summit Marina (Eb53-57), Fort Mott (Dd42-04), Delaware City (Dc53-07 and Ec14-01), New Castle (Cd51-21 and Cd51-23). The five lithofacies that make up the Potomac Formation, from McKenna et al. (2004) were the basis for the lithologic interpretations of this study.

Lithologic interpretations had previous been conducted for Glasgow (Thornburg, 2016), Summit Marina (Zullo, 2012) and the two wells from New Castle (McLaughlin, 2012). The lithologic interpretations for Bear/Christiana, both Delaware

City wells, Fort Mott, and Prest Property were conducted for this study. Interpretations of Bear/Christiana, and Prest Property were made using core photos, geophysical logs, on-site core descriptions made while drilling, as well as further re-examining of the core in the lab. The interpretations made for the two Delaware City wells and Fort Mott were based solely on geophysical logs and previous descriptions from publications (Doyle and Robbins, 1977; Sugarman et al., 2004) due to lack of available core samples. Where core sample was unavailable, only broader lithologic interpretations were able to be made with any accuracy.

The lithostratigraphic framework of the Potomac Formation, developed by Benson (2006), is the foundation for the stratigraphy of this study. Benson created an 
extensive network of cross sections, mainly concentrated in New Castle County, Delaware interpreting the three units of the Potomac Formation throughout the study area. His work included the stratigraphic correlations of the two Delaware City wells, the two New Castle wells, and the Fort Mott borehole used in this study. Those interpretations, plus the Summit Marina interpretations by Zullo (2016), were used to make correlations on the three new boreholes of this study (Bear/Christiana, Prest Property, and Glasgow). Benson did not have palynological data from the majority of his sites. By using geophysical logs alone, there is much room for improved correlation. The palynological results of the three boreholes of this study will take Benson's work and provide new accurate stratigraphic correlations. As new data within the Potomac Formation is collected it is worthwhile to return to Benson's work and reexamine his results. However, this is not within the scope of this study. 


\section{Dc11-15 Bear/Christiana}

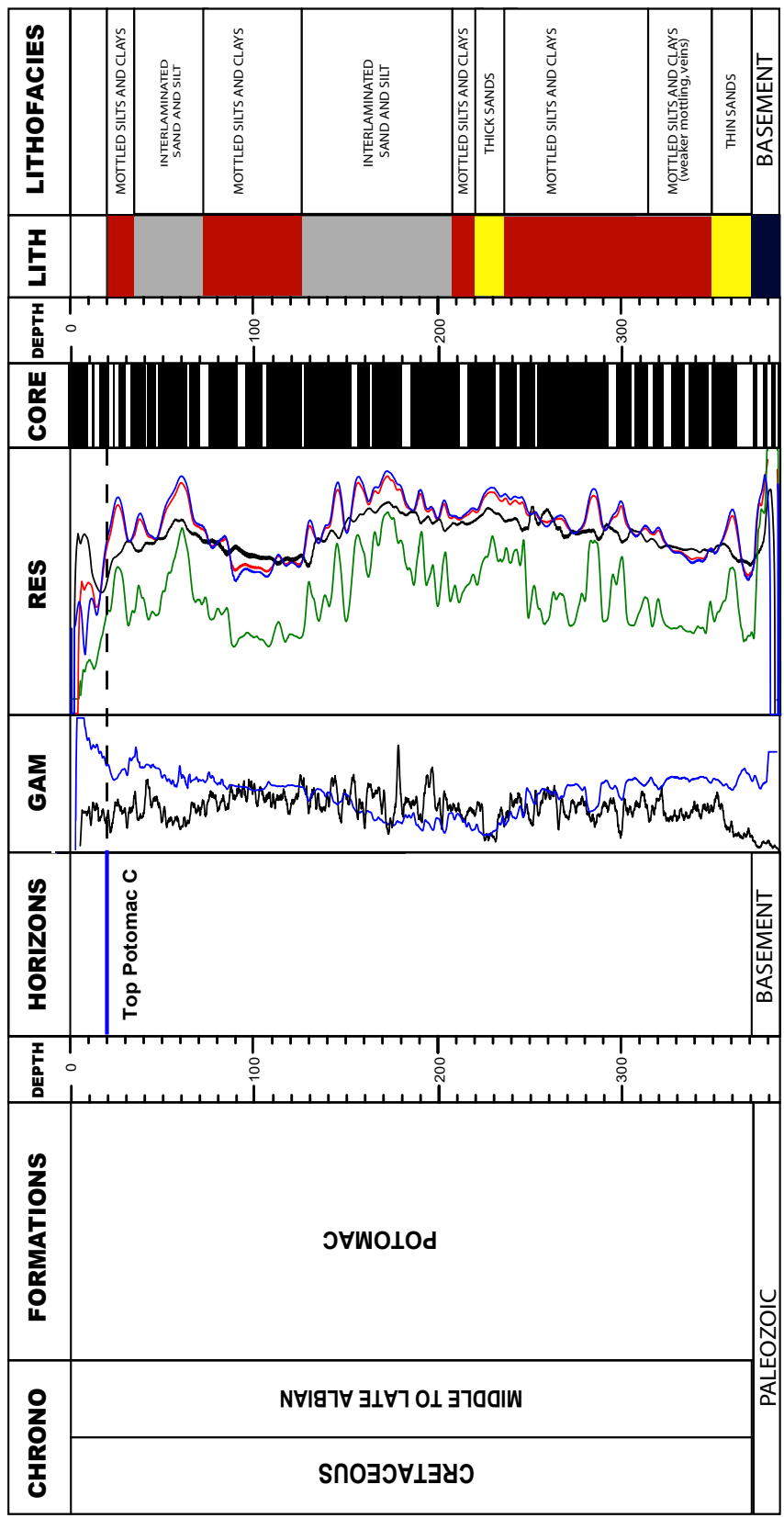

Figure 3.1 Stratigraphic log for the Bear/Christiana borehole, including units, geophysical logs, lithofacies, core recovery, formations (including the horizons within the Potomac Formation), and geologic age. 
The Bear/Christiana data set is made up of geophysical logs, new core that had been drilled for this study, and on-site geologist reports. The Potomac Formation is the only formation found in this location; it underlies Quaternary (?) surficial materials and overlies basement rock. The general trend in the lithologic composition of this borehole goes from very clay and silt rich with very few intermittent sands in the Potomac B unit to an overall sandier composition in Potomac C.

The first $12.2 \mathrm{ft}$ of the Bear/Christiana borehole were composed of man-made surficial fill. From 13 to $13.6 \mathrm{ft}$ are reddish brown and gray clays that are possibly the start of the Potomac Formation, or likely more reworked surface material. A sandstone makes up the bottom $0.2 \mathrm{ft}$, possibly formed through rise and fall of groundwater above an impermeable clay. The core from 15 to $20 \mathrm{ft}$ was unable to be recovered. Red and gray clays mark the first unquestionable sighting of the Potomac Formation at $20 \mathrm{ft}$. These clays extend to $36.8 \mathrm{ft}$ in depth, although 25 to $30 \mathrm{ft}$ was basically unrecovered. Charcoal pieces are seen throughout the dark gray clays, with a $0.02 \mathrm{ft}$ band at 2.96 to $2.98 \mathrm{ft}$. Clay and silt are by far the dominant lithologies in this section, however a small percentage of mostly fine, well sorted sand is found in almost every observed layer.

An interval of alternating silts, muds, and thin sands extends from 36.8 to 71.2 $\mathrm{ft}$ depth. From 36.8 to $39.8 \mathrm{ft}$ it is composed of medium to fine sand, with a layer of gray clay at 38.9 to $39.15 \mathrm{ft}$. This entire section is gray in color. Small traces of mica and charcoal occur throughout this section of the core. These mica and charcoal pieces 
are observed within both the clay and sand areas. From 44.8 to $71.2 \mathrm{ft}$ is an alternating pattern of very fine silt and clay packages, with [THIN?] fine- to medium-grained, well sorted, subangular to subrounded sand packages. Root traces and siderite nodules are seen within the clay layers, charcoal fragments seen in both clay and sand layers. Fine laminations are noted within the clay layers, and crossbedding is present from 50.7 to $50.9 \mathrm{ft}$. This entire section ranges from gray to dark gray in color. Overall, the sandy zones are made up of roughly $80 \%$ sand, and clay layers typically contain less than $10 \%$ sand. The log patterns support this interpretation due to the frequent peaks and valleys within both the gamma log and the resistivity log, indicating frequent changes in composition.

The cores samples between 75 and $127.2 \mathrm{ft}$ are predominantly mottled silts and clays. A clay rich layer with sandier laminations extends from 75 to $86.1 \mathrm{ft}$. Siderite nodules are prevalent throughout this section as well as siderite rich muds. The sandy laminations are predominantly clay but have a definite increase in the amount of sand. A sharp irregular contact is present at $86.1 \mathrm{ft}$ followed by a large package of mottled and banded clays. These mottled clays extend to $124 \mathrm{ft}$ deep. These clays range in color from gray, red, purple, and brown. Siderite remains present throughout this layer. Sections of banding (thin laminations), are present in packages from 100.4 to $108.55 \mathrm{ft}, 108.5$ to $110.2 \mathrm{ft}, 112.8$ to $113.4 \mathrm{ft}$, and 117.7 to $121.1 \mathrm{ft}$. The resistivity $\log$ shows a consistent low, indicating a high percentage of clay.

Silts and sands become the dominant lithology for the next grouped section from 127.2 to $202 \mathrm{ft}$. This section has mostly light-gray and reddish colors, like above, 
much of it is less intensely mottled than the overlying interval. From 127.2 to $128.5 \mathrm{ft}$ clays and silts are prevalent, overlaying a package of very fine, poorly sorted, subangular sand with charcoal and mica mixed in. These sands are red to dark gray, with the reds possibly being a result of the drilling mud mixing with the formation. At 128.5 to $130.55 \mathrm{ft}$ a very fine, poorly sorted, subangular sand makes up $80 \%$ of the layer, with organics prevalent throughout. The next five feet (130.55 to $135.55 \mathrm{ft})$ changes back to a $90 \%$ clay rich section with very little sand scattered throughout. The section of 135.55 to $137.2 \mathrm{ft}$ was made up of almost equal parts fine sand and clay, with both mottles and some fine banding. The next interval at 137.2 to $137.8 \mathrm{ft}$ is a medium to fine sand with thin laminations gray and brown gray. From 137.8 to 140.7 $\mathrm{ft}$ is a mixture of clay and fine to medium sand, mottling throughout. From 140.7 to $144.9 \mathrm{ft}$ is a gray, medium to fine sand with organic laminations, the section getting darker gray towards the base of the section. The next interval from 145 to $146.4 \mathrm{ft}$ is a reddish brown, medium to fine sand with a single 0.1 thick gray band and a single 0.1 $\mathrm{ft}$ thick brown band. From 146.4 to $151.6 \mathrm{ft}$ is a mottled clay with a small percentage of medium to fine sand.

The next interval, 151.6 to $155.95 \mathrm{ft}$, is a medium to fine sand with $30 \%$ clay content. The upper parts of this section are banded red and gray clay, transitioning to a brown/orange color that contains iron stone and some fine organic layers. By the base or this section, the content has transitioned back to the same as the upper section. From 155.95 to 156.55 is a clay layer interbedded with course sand. The next interval, 156.55 to $157.4 \mathrm{ft}$, is a medium to fine sand and clay with rip to up clasts within 
laminations. From 157.4 to $157.8 \mathrm{ft}$ is a coarse to medium sand. This section is more homogenous than previous sections with sand. The interval of 160 to $162.2 \mathrm{ft}$ is light gray clay with scattered small patches of brown fine sand. The next interval, 162.2 to $169.85 \mathrm{ft}$, is a medium sand layer with clay. This section contains laminations of red clay from 162.5 to $162.9 \mathrm{ft}$, followed by angular crossbedding of medium sand grained drapes. The majority of this section is brownish gray with various degrees of angled bedding with colors changing from weak red to gray to light brownish gray.

The next interval, 170 to $173.8 \mathrm{ft}$, is a weak red (possibly from the drilling mud), fine to coarse sand with clay pieces mixed within and a large gray slug of clay from 171.2 to $172.2 \mathrm{ft}$. From 173.8 to $174.9 \mathrm{ft}$ is a medium to fine, brown sand layer with gray clay laminations. Black iron cementations (about $1 \mathrm{~cm}$ ) also seen within the sand. The section from 180 to $186.5 \mathrm{ft}$ is clay with purple root structures with some brown discoloration. This layer is homogeneous with sand, silt, clay throughout. The section of 186.5 to $189.1 \mathrm{ft}$ is a light gray fine sand, slightly coarsening downward. The section from 189.1 to $189.5 \mathrm{ft}$ is a red clay containing quartz grains and siderite. The section from 190 to $193.4 \mathrm{ft}$ is red clay with dusky red root traces and blebs of light gray. Brown drab halos surround the darker root traces. From 193.4 to $195.4 \mathrm{ft}$ is a medium to fine sand with clay and traces of iron stone. Some red and brown banding at the top of the section with the majority being light gray the section of 195.4 to 198.3 $\mathrm{ft}$ is the same lithology as 190 to $193.4 \mathrm{ft}$, with less brown around the roots and more gray. From 198.3 to $199.65 \mathrm{ft}$ is a coarse sand with that gets coarsest at the base of this section. From 200 to $202 \mathrm{ft}$, is a fine to coarse light gray sand with some clay. 
The next grouped section, from 202 to 220 , is marked by a change to more clay-rich mottled and banded muds. The section of 202 to $205.1 \mathrm{ft}$ is a heavily mottled clay with frequent changes in color ranging from various shades of red and brown. From 205.1 to $208 \mathrm{ft}$, is a majority banded clay with colors the same as the previous section. From 208 to $208.2 \mathrm{ft}$ is a very fine well sorted sand, light olive brown in color. The interlaminated sand and silt interpretation is supported by the geophysical logs. Resistivity has overall increased, but not on a consistent basis due to the heterogeneity of this section. The gamma log also shows many inconsistencies supporting frequent changes in the lithology.

The section from 210 to $216.9 \mathrm{ft}$ is a brown, gray, and red clay layer (brown and gray being the dominant colors and alternating). Siderite nodules are common within the gray layers. From 216.9 to $219.65 \mathrm{ft}$ is a banded clay layer with some medium to fine sand. When coupled with the core observations, the geophysical logs support an increase in the amount of clay through a decrease in resistivity and consistency in the gamma.

A sandy interval occurs between 220 and $234.8 \mathrm{ft}$. From 220 to $228.8 \mathrm{ft}$ is a fine, well sorted sand with signs of angular crossbedding. Some thin bands of organics appear roughly every foot. From 230 to $230.5 \mathrm{ft}$ is a poorly sorted, very fine to coarse, light olive brown sand. From 230.5 to $231 \mathrm{ft}$ was a very poorly sorted, medium sized gravel with some coarse sand. Gravel is composed of quartz and light gray in color. From 231 to $234.8 \mathrm{ft}$ is a fine to coarse sand that gradually transitioned to gravels and pebbles. The grains in this section ranged from well sorted to very poorly sorted. The 
sand is clearly seen in the geophysical logs through a steep drop in the gamma log, and a high in the resistivity log.

A large package of mottled silts and clays interpreted as palesol and floodplain deposits lies from 234.8 to $347.9 \mathrm{ft}$. Intense mottling is prevalent throughout this section, becoming weaker and full of root traces towards the lower $40 \mathrm{ft}$.

Between 234.8 and $313.3 \mathrm{ft}$, the section returns to predominantly mottled silts and clays. At the top of this interval, from 234.8 to $237 \mathrm{ft}$, a dusky red clay contains small amounts of medium to fine sand. From 237 to $239.5 \mathrm{ft}$ is clay with medium to fine sand. This section is very similar to the last, except with a higher percentage of clay. From 240 to $243.9 \mathrm{ft}$ is a poorly sorted sand. This section coarsens downward, from a decreasing in amount of clay as well. From 243.9 to $248.8 \mathrm{ft}$ is a mottled clay section containing fine to coarse sand that also coarsens downward. From 248.8 to $249.1 \mathrm{ft}$ is a very thin-banded layer of clay. From 250 to $251.5 \mathrm{ft}$ is a silty mottled clay with medium to fine sand. From 251.5 to $254.9 \mathrm{ft}$ is a clay section with root traces. The section also contains very fine to fine sand and a large hematite concretion.

From 254.9 to $257 \mathrm{ft}$ is another clay-rich section, containing mottle and root traces with drab halos. From 257 to $259.5 \mathrm{ft}$ is a silty clay section also containing medium to fine sand. Overall grain size has increased in this section from the previous layers. This section contains brown and red banding, more heavily in some parts than others. From 260 to $261.75 \mathrm{ft}$ is a red silt section, high in quartz composition. From 261.75 to $263.2 \mathrm{ft}$ is very similar to the previous section but is much browner and less red. From 263.2 to $263.8 \mathrm{ft}$ is a solid dusky red section of clay rich in coarse sand, 
containing some quartz grains up to $2 \mathrm{~mm}$ in size. From 263.8 to $269.9 \mathrm{ft}$ is a light gray clay layer with medium to fine sand throughout. From 270 to $279.9 \mathrm{ft}$ is a clay section with fine to coarse sand. Multiple color changes from grayish brown and weak red transitioning to light gray and light olive brown. From 280 to $282.6 \mathrm{ft}$ is a poorly sorted, fine to coarse sand and clay section. At $281.3 \mathrm{ft}$ there is a single band of well rounded, light gray pebbles.

From 282.6 to 286.9 is a clay section with some thin bedding at an approximate 15-degree angle. From 290 to $296.2 \mathrm{ft}$ is a clay section with medium to fine sand. Faint mottling and fining upwards are the general trends. From 296.2 to $298.5 \mathrm{ft}$ is a very clay rich section with horizontal bedding at 294.2 to $294.5 \mathrm{ft}$ follow by multiple bedding planes to $294.7 \mathrm{ft}$ that cross creating an X pattern. From 300 to $302.3 \mathrm{ft}$ is a clay rich layer with coarse sand sized quartz grains, some gray blebs but overall dusky red. From 302.3 to $307.7 \mathrm{ft}$ is a clay rich section with large mottles in the top section, but not represented in the lower part. Main color is red with gray mottling. The section of 310 to $313.2 \mathrm{ft}$ is a silty clay with thin root structures, iron stone fragments, and hematite nodules.

Similar mottled red to gray silt and clay lithologies are present from 313.3 to $347.9 \mathrm{ft}$, but the degree of mottling is overall less well developed. A silt- and clay-rich medium to fine sand occurs between 313.3 to $313.55 \mathrm{ft}$. Overall color is light gray, with some brown blended with the section. From 313.55 to $315.6 \mathrm{ft}$ is sandy silty clay containing dark grayish brown, weak red, and light gray mottling. Mottles become more prevalent towards bottom of this section. 
From 320 to $328.05 \mathrm{ft}$ is a clay section with weak red mottles with cracks and veins. Some of the root traces filled with light gray and light brownish gray clay. Siderite and hematite are both present. From 330 to $333 \mathrm{ft}$ is a clay section with weak red mottling, some very faint brown discoloration. Hematite and iron manganese hematite crystals present. From 333 to $337 \mathrm{ft}$ is a sandy clay with dusky red, light gray, and weak red mottling surrounded by a brown drab halo. From 337 to $338.75 \mathrm{ft}$ is a clay section with light gray veins, some of which are filled with black organic material. From 340 to $340.9 \mathrm{ft}$ is a silty, sandy heavily mottled clay. Weak red, yellowish brown, and light gray in color with some quartz crystals within. From 340.9 to $343.5 \mathrm{ft}$ silty, sandy, clay with some well to rounded pebbles (about $1 \mathrm{~cm}$ in diameter). From 343.5 to $345.2 \mathrm{ft}$ is a similarly mottled and colored clay as seen in 340 to $340.9 \mathrm{ft}$. From 345.2 to $347.9 \mathrm{ft}$ is a very sandy clay with light mottling. Light gray is the dominant color of this section, transitioning to dark reddish gray towards the bottom.

Overall the geophysical logs are consistent with the descriptions of this section. With the exception of a few spikes in the resistivity log, the general trend is low. The gamma is consistently moderately high throughout this section as well, indicating clay content.

From 347.9 to $350.3 \mathrm{ft}$ is a silty clay rich, very fine to coarse sand. Sand is well sorted; overall grain size increases lower in the section. From 350 to $350.3 \mathrm{ft}$ is a sandy, clay rich silt, with quartz. From 350.3 to $350.7 \mathrm{ft}$ is a very coarse, poorly sorted sand with some rounded quartz pebbles up to $2 \mathrm{~cm}$ in size. From 350.7 to $351.5 \mathrm{ft}$ is a 
quartz gravel, average diameter of about $6 \mathrm{~cm}$. From 351.5 to $351.9 \mathrm{ft}$ is a solid piece of reddish gray quartz. From 360 to $360.4 \mathrm{ft}$ is made up of large quartz gravel and pebbles, these are cemented with some clay and medium sized clay. From 360.4 to $361 \mathrm{ft}$ is black, possibly from organics, in color. Chert pebbles are intermixed within the organics, along with medium sand mixed within the matrix. I this section the resistivity greatly increases, and gamma drops.

The last section of the Potomac Formation is seen from 365 to $365.03 \mathrm{ft}$. This is made up of the same black organics seen in the last recorded section. This section contains more recognizable signs of organic charcoal. Pebbles of chert are also mixed within the section. The top of weathered basement rock occurs at $365.03 \mathrm{ft}$ and is present to $379.8 \mathrm{ft}$; , on site, this was interpreted as the Ordovician aged Windy Hills Gneiss. 
Db55-14 Prest Property

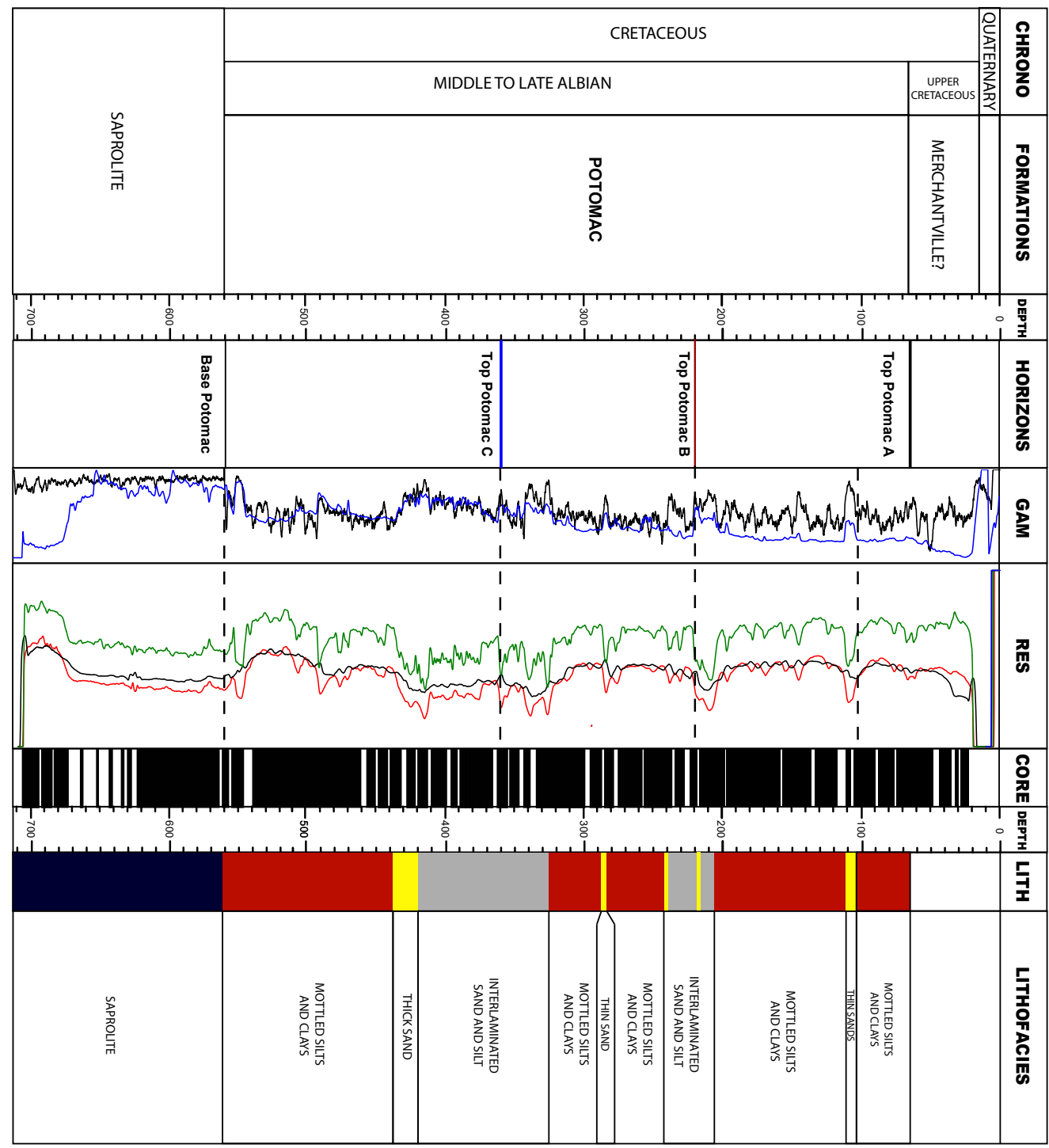

Figure 3.2 Stratigraphic log for the Prest Property borehole, including units, geophysical logs, lithofacies, core recovery, formations (including the horizons within the Potomac Formation), and geologic age. 
The lithologic data set for the Prest Property location is made up of geophysical logs, core, and drillers reports. In this study, onsite core descriptions are compiled into a comprehensive record of lithology and new interpretations of horizons and intervals are presented. The Potomac Formation underlies the Merchantville Formation at $61.75 \mathrm{ft}$ deep, and directly overlies saprolite at $565 \mathrm{ft}$. The top half of the Potomac Formation in this location is composed of silts and clays with few intermittent thin sand packages. The lower half of the Potomac Formation in this location is also predominantly silts and clay, with the exception of one sand package that is thicker than any of the thin sands in the upper half of the formation.

Grouped sections were identified within the core based on their lithlogic properties (mottled silts and clays from 61.75-105.8, thin sands from 105.8-111.9, mottled silts and clays from 111.9-208, interlaminated sands and silts from 208-241, mottled silts and clays from 241-284.2, thin sands 284.2-287.3, mottled silts and clays from 287.3-324.7, interlaminated sand and silts from 324.7-420.9, thick sand from 420.9-438.2, and a mottled silt and clay section from 438.2 to the saprolite basement at $565 \mathrm{ft}$.). These sections are shown on figure 3.2; red representeding mottled silts and clays, gray for interlaminated sands and silts, and yellow for sands.

The Potomac Formation underlies the Merchantville Formation beginning at $61.75 \mathrm{ft}$ in depth. The Potomac Formation begins with a gray silt and clay section from 61.75 to $69.6 \mathrm{ft}$. This section contains charcoal fragments and light pinkish gray mottling. 
The next bed is a section of red, light gray, grayish olive clay. This bed extends from 70 to $105.8 \mathrm{ft}$, becoming mottled deeper in the core. The bottom $15 \mathrm{ft}$ of this bed contains frequent mottling transitioning into a more silt rich clay.

From 105.8 to $111.9 \mathrm{ft}$ is a silty, very fine sand layer with charcoal and plant fragments. From 111.9 to $113.35 \mathrm{ft}$ is a silt layer with sand and clay clast. Reddish gray mottling is prevalent throughout the first foot of this section. From 113.35 to $114.1 \mathrm{ft}$ is a slightly silty clay layer with olive gray mottles. From 120 to $138.8 \mathrm{ft}$ is a thick layer of clays and silts. Banded sections and heavily mottled section are present throughout the entire section. From 140 to $151 \mathrm{ft}$ is a very silty clay layer containing sphaerosiderites and small patches of mottling. An irregular contact is present at $151 \mathrm{ft}$ giving way to a clay layer from 151 to $164.6 \mathrm{ft}$. This clay is very silty, and full of laminations. From 164.6 to $170 \mathrm{ft}$ is a silty weakly mottled clay. From 170 to $197.4 \mathrm{ft}$ is a clay layer with alternating sections of mottling and banding. Mottling is more prevalent throughout this layer. At 184.65 to $184.8 \mathrm{ft}$ is a solid layer of dark red silty clay. Colors alternate between reddish gray, bluish gray, weak red, olive gray, and dark reddish gray. From 197.4 to $199.3 \mathrm{ft}$ is a nearly homogeneous silt layer, containing very small amounts of clay and sand. From 200 to $205.2 \mathrm{ft}$ is a clay section with rounded mottles towards the top of the section and larger fewer uniform mottles towards the base. From 205.2 to $206.5 \mathrm{ft}$ is a clay layer with silt sand, and traces of mica. A gradational contact at $206.5 \mathrm{ft}$ overlies a sandy bluish gray silt layer with red mottles. 
Another gradational contact at $208 \mathrm{ft}$ give way to a very fine sand layer with black grains of organic plant matter or charcoal, this section extends to $212.8 \mathrm{ft}$ deep. From 212.8 to $213.1 \mathrm{ft}$ is a layer of silt with mica and few black grains. From 213.1 to $215.5 \mathrm{ft}$ is a very fine well laminated sand layer. From 215.5 to $217.5 \mathrm{ft}$ is a silt layer containing sand, mica, and charred plant fragments.

From 217.5 to $218.4 \mathrm{ft}$ is a section of very fine sand with a small percentage of black grains due to OHM or charcoal particles. From 218.4 to $221.5 \mathrm{ft}$ is silt, still with some sand and an increase in the amount of black grains from the last layer. This is followed by a sharp contact overlying a silty clay layer from 221.5 to $236.6 \mathrm{ft}$. The color varies from between red and light gray throughout this layer. From 240 to $241 \mathrm{ft}$ is a layer of very fine, light gray sand.

The next section from 241 to $284.2 \mathrm{ft}$ is made up of clays with characteristics mostly uniform to one another but varying a small amount throughout. The section is heavily mottled in some parts and less mottled in others. Color of the mottling is also variable, ranging between purple, red, gray, brown, and rusty red.

From 284.2 to $287.3 \mathrm{ft}$ is a sand layer alternating between cleaner and muddier. Sand is very fine with alternations between cleaner and muddier beds/laminae.

The section from 287.3 to $288.1 \mathrm{ft}$ is laminations of clay and sand. These alternate in 1 to $6 \mathrm{~cm}$ packages. From 288.1 to $288.9 \mathrm{ft}$ is a clay layer with a dark gray to black color to it. From 290 to $290.75 \mathrm{ft}$ is a dark gray and dark grayish brown clay with faint mottles. From 290.75 to $295.5 \mathrm{ft}$ is a light gray clay with faint red to brick 
red splotches. Hematite concretions and sphaerosiderites getting higher in concentration deeper in the section. From 295.5 to $298.75 \mathrm{ft}$ is a very silty, slightly sandy, clay. Very faint mottling, and very faint laminations throughout this overall homogeneous section. From 298.75 to $300.4 \mathrm{ft}$ is a very silty clay with red mottles. Less homogenous than the previous layer. From 300.4 to $308.6 \mathrm{ft}$ is a silty clay with transitional boundaries at $303.2 \mathrm{ft}, 304.1 \mathrm{ft}, 304.8 \mathrm{ft}, 305.6 \mathrm{ft}, 307.1 \mathrm{ft}, 307.9 \mathrm{ft}$, and $308.7 \mathrm{ft}$. This section is rich in sphaerosiderite and hematite. The color changes at the transitional boundaries from weak red with reddish brown to brown to weak red, grayish brown with olive to mottled dark gray to gray to a banded layer of gray. From 308.7 to $309.65 \mathrm{ft}$ is faintly laminated, featureless, light gray clay. From 310 to 312.3 $\mathrm{ft}$ is an overall homogenous clay layer with small amounts of silt and sand. The lowest $0.2 \mathrm{ft}$ of this section has a diffused contact giving way to a very muddy sand. From 312.3 to $312.9 \mathrm{ft}$ is a silty, slightly sandy, clay containing charcoal fragments. From 312.9 to $313.4 \mathrm{ft}$ is a diamictite layer. This is a mix of clasts of very fine to medium sand and some siderite cementations.

From 313.4 to $314.3 \mathrm{ft}$ is an interlaminated sand and clay. This layer overlies a diffuse contact giving way to a very clay rich, sandy, silt that extends $317.8 \mathrm{ft}$. A second consecutive diffuse contact is at $317.8 \mathrm{ft}$, overlying an interlaminated sand and silt (more silt than sand) layer. This layer extends to $322.2 \mathrm{ft}$. Following a gradational contact at $322.2 \mathrm{ft}$ is a very clay rich, slightly mottled silt. Another gradational contact at $323.8 \mathrm{ft}$ overlies an interlaminated silt and sand with subtle to uneven banding with some mottling as well. This layer extends to $324.7 \mathrm{ft}$. 
A thick package of interpreted intelaminated sands and silts was interpreted from 324.7 to $420.9 \mathrm{ft}$. From 324.7 to $325 \mathrm{ft}$ is a very fine sand layer that is very soft, almost runny. From 325 to $325.4 \mathrm{ft}$ is dark gray clay layer with a thin sand lamination near the middle. From 325.4 to $329.2 \mathrm{ft}$ thick, clean sand section with parallel laminations. A gradational contact at $329.2 \mathrm{ft}$ overlies a clay and silt layer that is also very sandy. The sand appears to be the same as the layer above except infiltrated with a large amount of mud. This section extends to $337.2 \mathrm{ft}$. with a thin clay lamination from 331.3 to $331.4 \mathrm{ft}$. Sandier zone are found at 332.4 to $332.9 \mathrm{ft}, 335.25$ to 335.45 $\mathrm{ft}, 335.6$ to $336 \mathrm{ft}$. From 340 to $340.1 \mathrm{ft}$ is a dark gray soft mix of silt and clay with a small amount of poorly sorted sand. From 340.1 to $343.8 \mathrm{ft}$ is an overall clean sand section with a mud-rich zone 344.1 to $344.7 \mathrm{ft}$. From 343.8 to $344.3 \mathrm{ft}$ is a conglomerate made up of mostly light gray clay clasts and pebbles. This overlies a sandy, slightly clay rich, silt layer from 344.3 to 344.55 . From 350 to $356.8 \mathrm{ft}$ is silty, slightly sandy clay with burrows present. Underlying a transitional contact at 356.8 is an interlaminated sand and clay layer. This layer extends to $359.05 \mathrm{ft}$. From 359.05 to $361.1 \mathrm{ft}$ is a clay layer with faint laminations. From 360.1 to $360.4 \mathrm{ft}$ is a layer of peat with fragments of charcoal. From 360.4 to 362.2 is a sand layer that transitions to a much muddier sand towards to bottom. From 362.2 to $367.9 \mathrm{ft}$ very silty, light gray clay with some banded zones as well as signs of bioturbation. From 370 to 372.3 is a sandy, clay rich silt. Some mottling is present towards the base of this layer. From 372.3 to $375.4 \mathrm{ft}$ is slightly sandy, clay rich silt with alternating laminations of very sandy and very silty zones. From 375.4 to $376.75 \mathrm{ft}$ is a sand and silt layer. This 
section is interlaminated with fairly regular alternation. From 377.5 to $390.3 \mathrm{ft}$ is an interbedded, interlaminated silt and sand section. This section alternates from sandier zones to muddier with siderite nodules appearing lower in the section. From 391 to $391.5 \mathrm{ft}$ is a sand layer ranging from fine to very fine. This layer contains inclined planes of parallel laminae. From 391.5 to $395.6 \mathrm{ft}$ is a silt and clay layer with large siderite nodules throughout. From 395.6 to $397.3 \mathrm{ft}$ is a sand layer with interlaminated silt. Some dark organic layers are found within the sands. From 397.3 to $398.1 \mathrm{ft}$ is a repeat of the same silt and clay layer from 391.5 to $395.6 \mathrm{ft}$. From 398.1 to $420 \mathrm{ft}$ is a silt section with interlaminated sand zone. Sand zones are thicker, cleaner, and more abundant towards the base of this section. An uneven contact at $420 \mathrm{ft}$ overlies a clay section with possible burrowing. This section extends to $420.9 \mathrm{ft}$.

A new grouped section was idenitifed from 420.9 to $438.2 \mathrm{ft}$ as a thick sand package. From 420.9 to $421.6 \mathrm{ft}$ is a poorly sorted medium to coarse sand layer, alternating with organic debris. From 421.6 to $423.8 \mathrm{ft}$ is a mud and sand layer, alternating between the two. Pyrite is present in this section, as well as mud clasts. At the base of this interval is a $0.5 \mathrm{ft}$ thick section of sand with peat and charcoal fragments. From 425 to $430.6 \mathrm{ft}$ is an alternating mud and sand section with sand layers being very thin and very muddy. From 430.6 to $432.1 \mathrm{ft}$ is a very sandy poorly sorted silt. The bottom $0.4 \mathrm{ft}$ of this section is made up of horizontal tube to like structures, possibly roots. From 435 to $438.2 \mathrm{ft}$ is a very sandy, slightly clay rich silt. A lot of small holes are present, possible being the remnants of roots. 
A new grouped section of mottled silts and clays was interpreted from 438.2 to basement saprolite at $565 \mathrm{ft}$. From 438.2 to $442.8 \mathrm{ft}$ is a clay section with more silt in the top $2 \mathrm{ft}$, transitioning to slightly silty in the bottom $2 \mathrm{ft}$. The section shifts from mottles to banded to mottled to banded. From 442.8 to $453.6 \mathrm{ft}$ is a slightly sandy silt frequently transitioning between mottled to banded. From 455 to $461.75 \mathrm{ft}$ is a very clay rich silt. The section transitions from mottled to banded to mottled and back to banded. From 465 to $472.3 \mathrm{ft}$ is a slightly sandy clay with abundant mica. The bottom $1.3 \mathrm{ft}$ of this section is a very sandy clay. From 472.3 to $475 \mathrm{ft}$ is a clay section. This section is banded for the top $0.1 \mathrm{ft}$ and mottled the rest. Sphaerosiderite nodules are abundant in certain zones of this section. From 475 to $490.5 \mathrm{ft}$ is a clay section transitioning between very sand zones and very silty zones. The majority of this section is featureless with the exception of small banded zones, and some mottled zones.

From 490.5 to $493.6 \mathrm{ft}$ is a very silty, clay rich sand. Banding and laminations are present throughout the entire section, banding denser in some places than others. From 493.6 to $495 \mathrm{ft}$ is a very silty clay with hard, dry mottles. From 495 to $504.9 \mathrm{ft}$ is a heavily mottled clay with multiple color transitions. Brown, olive, red, and gray are the dominant colors throughout this section. From 505 to $507.3 \mathrm{ft}$ is a very sandy, silty clay that transitions at $505.5 \mathrm{ft}$ to a very clay rich sand. Both sections contain abundant charcoal fragments. From 507.3 to $509.4 \mathrm{ft}$ is a clay rich, silty sand. Light sand filled roots or possibly burrows are common through this section. Section get sandier towards the base. 
From 509.4 to $515 \mathrm{ft}$ is a heavily mottled silt with small amounts of clay and sand. Section gets darker in color towards the base. From 515 to $522 \mathrm{ft}$ is a silty, slightly sandy clay section. This section is very similar to the previous one, with increasing in amount of silt towards the base. At $522 \mathrm{ft}$ is a severely angled contact overlying a silt section containing multiple hematite concretions down to $525.4 \mathrm{ft}$. From 525.4 to $529.6 \mathrm{ft}$ is a silty, hard, dry clay section. Mottling is abundant, surrounded by prominent drab halos. The base $0.3 \mathrm{ft}$ of this section becomes finely banded. From 529.6 to $535.1 \mathrm{ft}$ is a silt and fine to grained sand section. Mottle occurs at the top but is less present in the base of the section. From 535 to $541.3 \mathrm{ft}$ is a silty clay with heavy deep red and purple mottling. The base of this section transitions in a siltier lithology with yellow and red mottling. From 541.3 to $556.8 \mathrm{ft}$ is a very clay rich and silty sand. Sand is poorly sorted, mostly fine grained still containing mottles like the previous sections. From 556.8 to $559.6 \mathrm{ft}$ is a slightly looser, coarser than the previous layer, very silty sand. Faint current ripples are present in some sections, as well as bands of mottling. From 560 to $560.4 \mathrm{ft}$ is a very clay rich, silty sand. Sand is mostly medium to fine grained, but there are coarse grains even some small pebbles. From 560.4 to $564.1 \mathrm{ft}$ is a distinctly rusty red and light yellowish gray mottled sand. Sand is clay rich and silty, including some "chunks" of clay. Microsphaerosiderites and hematite nodules are very abundant in the section. The lowest interval in the Potomac Formation, before reaching saprolite at $565 \mathrm{ft}$, is a mottled sand overlying angular pebbles, roughly $15 \mathrm{~mm}$ in size. 
The geophysical logs support the interpretations of the lithologies made above. Mottled silts and clays are indicated by lows in resistivity and increases in gamma. Thin sands, such as at $105 \mathrm{ft}$, appear in the resistivity logs as spikes that quickly decrease. The sections of interlaminated sands and silts have high amounts of variability, showing in the logs as inconsistent packages with frequent changes in the lithologic composition. 
Db41-32 Glasgow

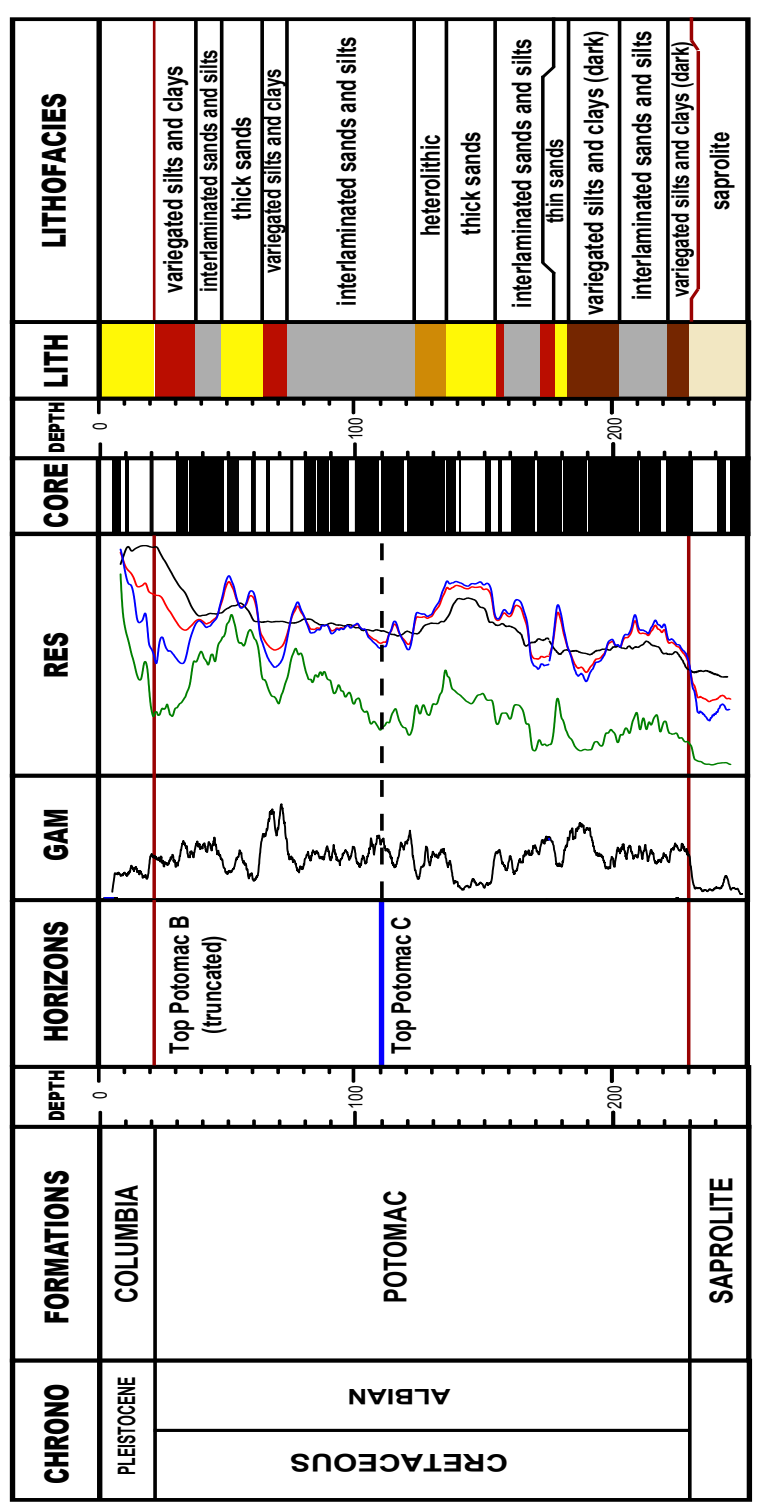

Figure 3.3 Stratigraphic log for the Glasgow borehole, including units, geophysical logs, lithofacies, core recovery, formations (including the horizons within the Potomac Formation), and geologic age. Figure from McLaughlin, 2012. 
The data set for the Glasgow borehole is made up of geophysical logs, core, and on-site geologist reports. The Potomac Formation in this location underlies the Colombia Formation interpreted at $20 \mathrm{ft}$, and directly overlies saprolite at $230 \mathrm{ft}$. The first appearance of the Potomac Formation is interpreted as Potomac B. The upper half of the Potomac Formation contains one thick sand bed within thicker layers of silts and clays. The top of Potomac $\mathrm{C}$ is interpreted at $110 \mathrm{ft}$ in depth, about midway through the core. The bottom half of the Potomac Formation also is composed of multiple silt and clay layers, but also contains a thick sand bed (thicker than sand bed in the upper half), as well as a thin sand bed.

The Glasgow borehole was also grouped into grouped sections of lithologic packages. The upper most Potomac Formation sediments were grouped into a package of overall variegated silts and clays from 30 to $35.06 \mathrm{ft}$. The Potomac Formation at the Glasgow location is first recovered at $30 \mathrm{ft}$ in depth. In this location the Columbia Formation overlies the Potomac Formation. The first recovered section of the Potomac Formation is from 30 to $34.5 \mathrm{ft}$. This section is made up of silt, sand, and clay. From 30 to $30.08 \mathrm{ft}$ is laminated sand with lignite pieces at the top. From 30.08 to $31.1 \mathrm{ft}$ becomes more clayey. From 31.1 to $32.2 \mathrm{ft}$ is silt with clay. Color banding in yellow and white layers, red mottling is present at the bottom. From 32.2 to $32.6 \mathrm{ft}$ is silt with sand, this layer is more homogenized that the previous. From 32.6 to $34.5 \mathrm{ft}$ is gray clay with red and yellow mottles throughout. Hematite, limonite, and siderite are present in this section. From 35 to $35.06 \mathrm{ft}$ is very fine sand with silt and clay. Similar irregular color banding is present here as the above section. 
The next grouped section was an overall interlaminated sand and silt bed from 35.06 to $50 \mathrm{ft}$. From 35.06 to $37.7 \mathrm{ft}$ is very fine sand with silt. Thin layers of clay, roughly 0.1 to 0.2 in thick, are present in this section. From 37.7 to $38.2 \mathrm{ft}$ is a fine to very fine sand that has a mottled red appearance. From 38.2 to $39.65 \mathrm{ft}$ is a sandy, mica rich clay. Large root traces and bioturbation are present in this section. From 40 to $42.6 \mathrm{ft}$ is silty, clay rich sand with fragments of lignite. From 42.6 to $42.8 \mathrm{ft}$ is a thick clay. From 42.8 to $48.9 \mathrm{ft}$ is unconsolidated sand bed with layers of clay at 43.3 $\mathrm{ft}$ and from 47.3 to $47.5 \mathrm{ft}$. The gamma log readings are relatively high and the resistivity readings are inconsistent in this section. This indicates a high amount of heterogeneity within the silts and clays.

An overall thick sand bed was grouped from 50 to $65 \mathrm{ft}$. From 50 to $54.7 \mathrm{ft}$ is a sand layer with multiple color changes, ranging from olive gray, dark gray, and brownish yellow. From 60 to $60.3 \mathrm{ft}$ is a very fine sand layer, containing some quartz, mica, silt, and clay. A large spike in the resistivity log indicates that this section is a relatively clean sand, with little silt or clay infiltration.

A thin overall variegated silt and clay bed was interpreted from 65 to $75.3 \mathrm{ft}$. From 65 to $66.4 \mathrm{ft}$ is a red and brown mottled clay layer with hematite and siderite present. From 75 to $75.3 \mathrm{ft}$ is a piece of mostly fine to grained sandstone. This is a possible reason for lack of recovery in this section of the core.

The largest grouped bed was interpreted from 75.3 to $122.8 \mathrm{ft}$ as interlaminated sand and silt. From 75.3 to $106.5 \mathrm{ft}$ is a section of interlaminated sand and clay. Each layer of either sand or clay being about .5 to $1 \mathrm{ft}$ thick. From 106.5 to $109 \mathrm{ft}$ is a mix 
of very fine sand and clay. This section contains lots of burrows or root cast, and charcoal. From 110 to $116.8 \mathrm{ft}$ is a clay section with charcoal and concretions throughout. At 114.5 to 114.7 is a solid band of very fine laminated sand. From 116.8 to $118.3 \mathrm{ft}$ is a silty, sandy clay with large pieces of charcoal throughout. From 118.3 to $118.5 \mathrm{ft}$ is another piece of solid, very fine to grained sandstone. From 120 to 122.8 $\mathrm{ft}$ is a dark gray clay. Both the gamma and resistivity logs are inconsistent indicating that this section has frequent changes in composition.

From 122.8 to 136.1 is a sand and clay section. This section is very heterolithic, containing pieces of charcoal, siderite, and sandstone. Followed by an abrupt contact, is sand from 136.1 to $138.9 \mathrm{ft}$. Crossbedding and organic plant matter are present within this section. From 140 to $140.5 \mathrm{ft}$ was the next recovered section. This was composed of medium, well sorted sand. From 150 to $151.1 \mathrm{ft}$ is sand, with a $0.1 \mathrm{ft}$ thick section of sandstone at the base of this section. From 151.1 to $155.6 \mathrm{ft}$ is a layer of silt with faint mottling, some organic root traces as well. From 155.6 to 156.2 $\mathrm{ft}$ is a thin layer of very silty sand with charcoal pieces. A blocky pattern of high gamma and low resistivity support this interpretation of thick sand.

From 160 to $160.6 \mathrm{ft}$ is a sandy clay with large charcoal pieces. From 160.6 to $165.2 \mathrm{ft}$ is a very fine grained, laminated with beds of sandy clay, sand. From 165.2 to $167.4 \mathrm{ft}$ is a clay layer with abundant laminae of very fine sand. Clay is very silt rich in some of the section. From167.4 to $167.8 \mathrm{ft}$ is a sand layer with interlaminated clay. From 167.8 to $169.2 \mathrm{ft}$ is silty clay. This layer is faintly banded but still slightly homogenous. From 170 to $177.6 \mathrm{ft}$ is a heavily mottled clay. Laminations, siderite, 
and organics present in this layer. From 177.6 to $179.65 \mathrm{ft}$ is a fine to very fine sand layer with a $0.1 \mathrm{ft}$ thick band of charcoal at the base. From 180 to $181.9 \mathrm{ft}$ are alternating roughly $0.5 \mathrm{ft}$ thick beds of sand and clay. The gamma log increases from the thick sand section indicting that there is clay present at the top of this section. The resistivity drops but remains high overall, indicating that there is a percentage of sand, just not as much as above.

From 181.9 to $196.1 \mathrm{ft}$ is a thick bed of clay containing laminations at the top, and mottles at the base. There is a transition in this bed from darker more laminated clays and silts at 181.9 to 186.5 to lighter sediments. From 196.1 to $197.8 \mathrm{ft}$ is a sandy, clay rich silt overlaying a very fine sand layer with blebs of gray clay from 197.8 to $199.85 \mathrm{ft}$. From 200 to $201.3 \mathrm{ft}$ is a medium to fine sand layer, also rich in clay. From 201.3 to $205 \mathrm{ft}$ is a clay layer with large pieces of charcoal throughout. A distinctly lighter section is present from 202 to $203.7 \mathrm{ft}$ also containing faint mottles are also present in this section. This lithologic interpretation is represented by high gamma and low resistivity on the logs.

From 205 to $205.4 \mathrm{ft}$ is a solid piece of charcoal. From 205.4 to $209.7 \mathrm{ft}$ is layer of clay with concretions and charcoal. This section ranges from being more ordered in some parts to more mixed in terms of the charcoal and concretions. From 210 to 211.5 $\mathrm{ft}$ is a silty clay section. From 211.5 to $212.2 \mathrm{ft}$ is a very fine sand with some charcoal pieces. From 212.2 to $214.4 \mathrm{ft}$ is a clay section with silt and lots of charcoal mixed throughout. From 216.4 to 217 is a sand layer becoming increasingly clay rich towards the base. From 217 to $217.9 \mathrm{ft}$ is a solid piece of charcoal. From 220 to $223.75 \mathrm{ft}$ is a 
layer of clay. Silt, sand, and charcoal are prevalent throughout this layer. Inconsistent gamma and high resistivity are indicative of this interpretation.

From 223.75 to $224.1 \mathrm{ft}$ is a thin bed of sand, followed by a thick layer of clay and silt from 224.1 to $230 \mathrm{ft}$. Mottles and charcoal are prevalent throughout this section, which is the final layer before the saprolite at this location. 


\section{Dc53-07 Delaware City}

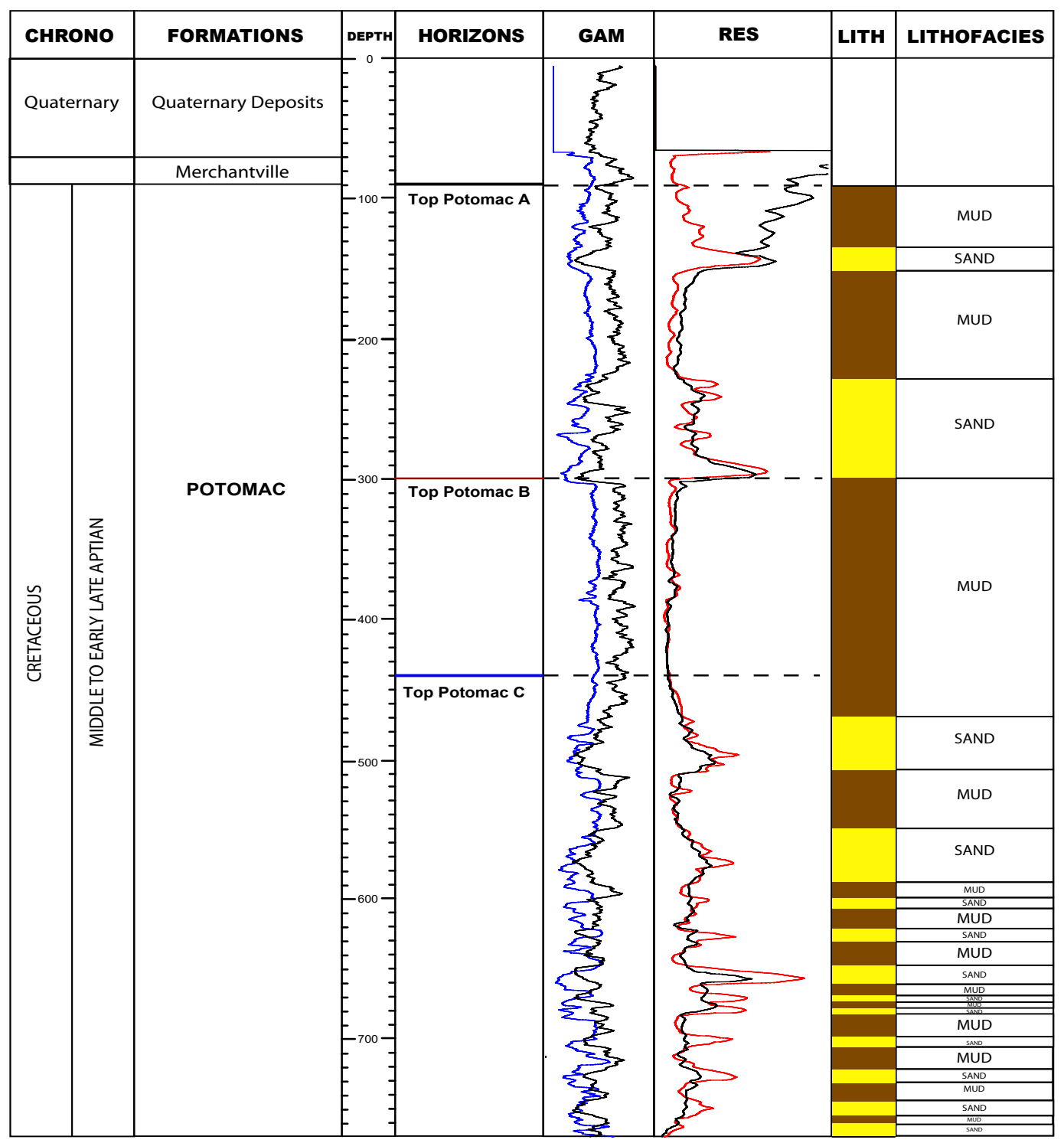

Figure 3.4 The Dc53-07 borehole is shown here side by side with the geophysical logs, lithofacies, core recovery, formations (including the horizons within the Potomac Formation), and geologic age. 
The data for the Delaware City borehole Dc53-07 was limited only to geophysical logs. Due to this limit data set, the only general lithologic interpretations could be made with any degree of confidence. Each section of the log was interpreted as one of the following two lithologies, sand or mud. The top of Potomac A was interpreted as being $90 \mathrm{ft}$ in depth and $210 \mathrm{ft}$ thick. The unit lies beneath the Merchantville Formation, which underlies Quaternary deposits. The uppermost Potomac sediments are interpreted as thick packages of clay with intermittent sand bodies. Potomac A is composed of roughly $50 \%$ sand and $50 \%$ mud. Potomac B is interpreted at $300 \mathrm{ft}$ in depth and $140 \mathrm{ft}$ thick. This unit is interpreted as being composed entirely of mud.

Potomac $\mathrm{C}$ is interpreted at $440 \mathrm{ft}$ deep, with much more heterogeneity than the previous two units. From $600 \mathrm{ft}$ to the base of the geophysical logs, at roughly 770 $\mathrm{ft}$, are thin alternating beds of clay and sand. These beds are at most $20 \mathrm{ft}$ thick, opposed to the previous section where beds were at least $40 \mathrm{ft}$ thick. The total amount of sand in this section is greater than above, the overall thickness of the sand beds is than above. 


\section{Ec14-01 Delaware City}

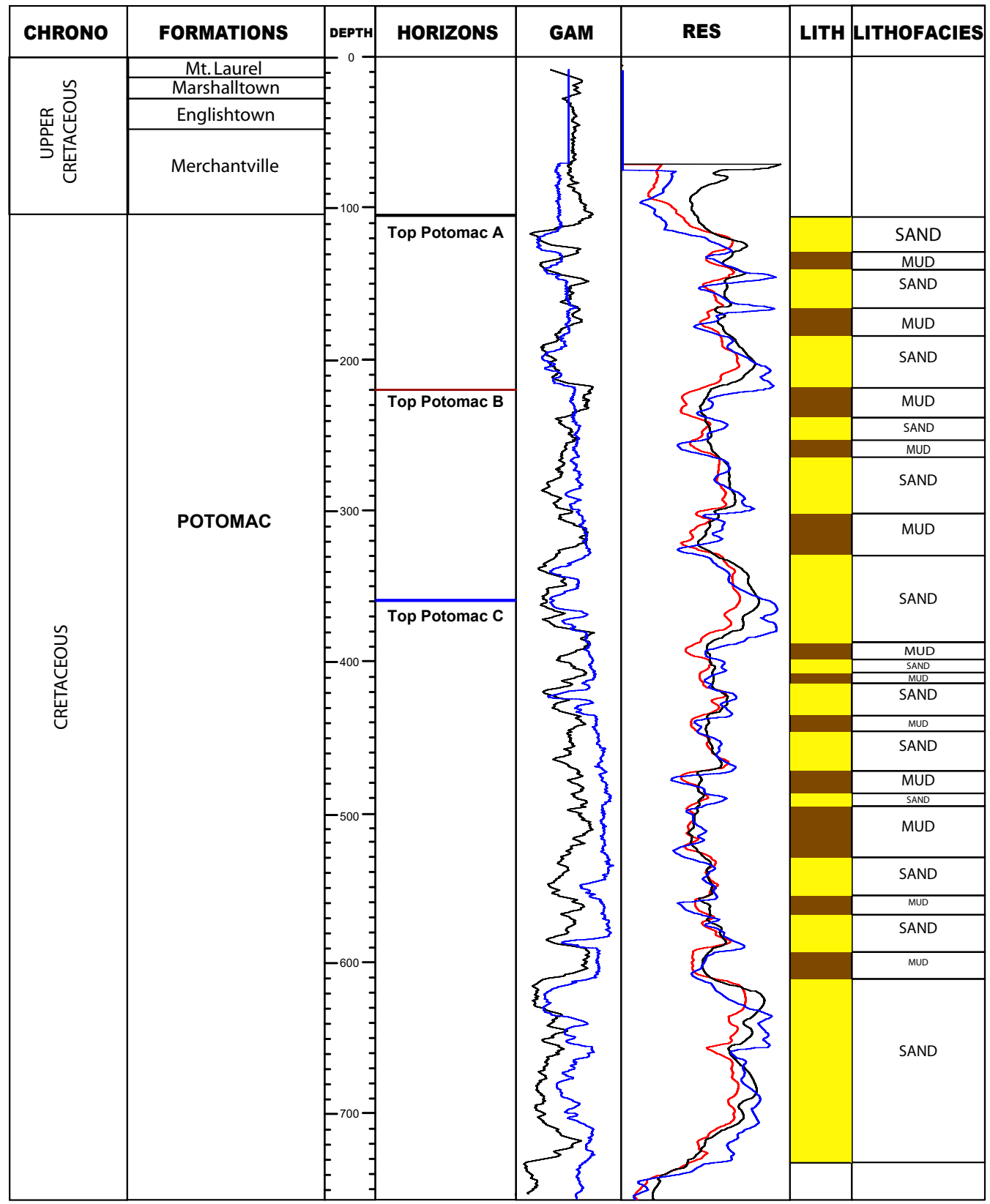

Figure 3.5 The data for the Ec14-01 Delaware City borehole is shown here side by side with the geophysical logs, lithofacies, core recovery, formations (including the horizons within the Potomac Formation), and geologic age. 
The data set for Delaware City borehole Ec14-01 was limited to geophysical logs. The same procedure was conducted for Ec14-01 as Dc53-07. Two general lithologies, mud and sand, were interpreted based on the geophysical log.

The top of Potomac A was interpreted at roughly $105 \mathrm{ft}$ and the top of Potomac $\mathrm{B}$ at $220 \mathrm{ft}$ to $360 \mathrm{ft}$ deep. These two units have similar lithological trends, concerning the size and frequency of the sand and clay beds. The average thickness of each bed is between 15 to $30 \mathrm{ft}$, this trend consistent between the sand and clay compositions. The overall composition of these two units is roughly $50 \%$ sand, $50 \%$ mud. The logs show a spike in resistivity at the contact between Potomac A and B and maintain a spikey pattern throughout.

The top of Potomac C lies at roughly $360 \mathrm{ft}$ deep. The top $250 \mathrm{ft}$ of this unit is made up of much thinner beds than the previous two units. These beds follow the same general trend as the last two units, slightly varying in thickness but overall composition being split 50\% sand, 50\% mud. At $610 \mathrm{ft}$ is interpreted as the start of a thick, possibly clean, sand bed that extends to the base of the geophysical log at $740 \mathrm{ft}$ deep. 
Dd42-04 Fort Mott

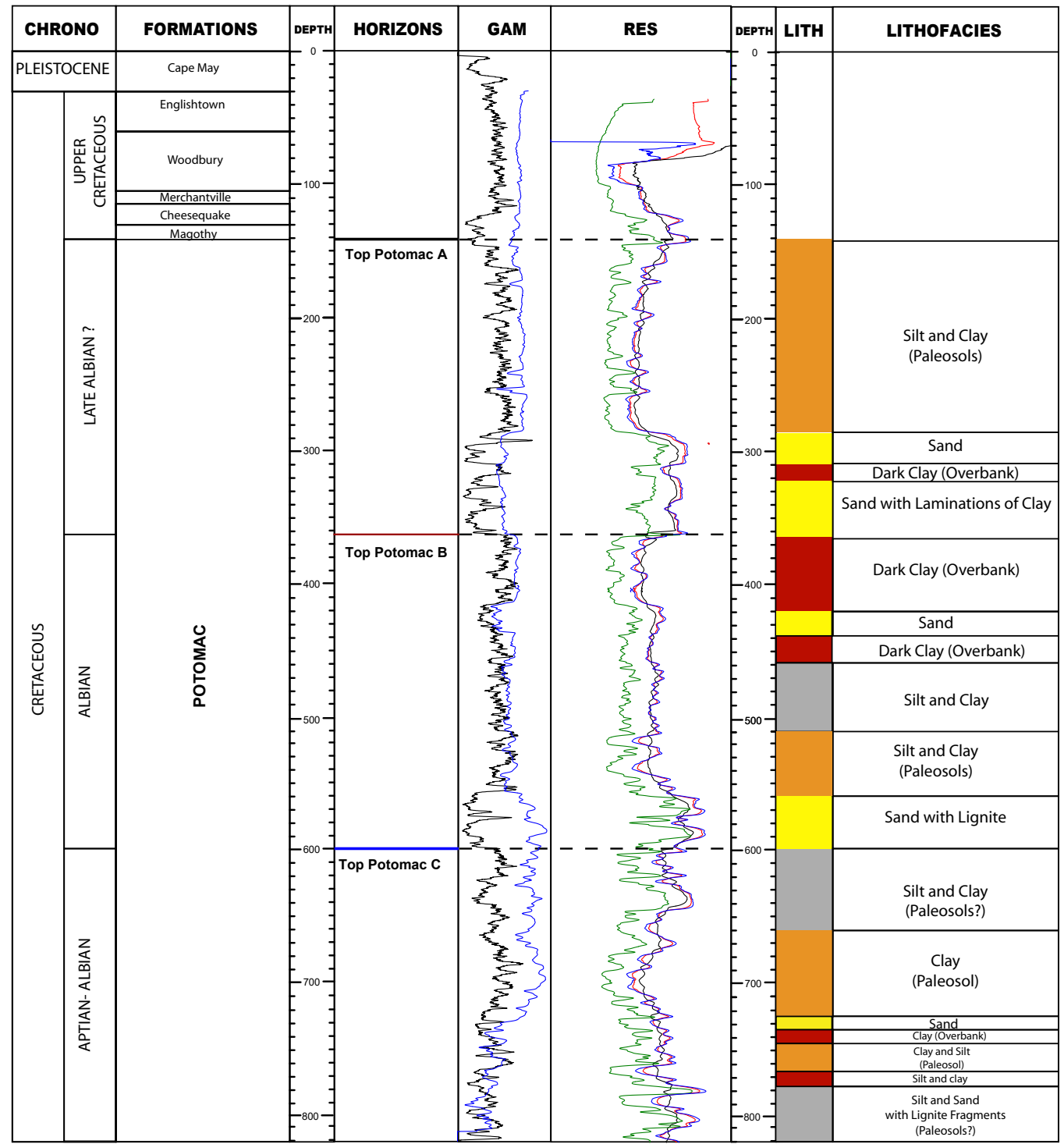

Figure 3.6 The data for the Fort Mott borehole is shown here side by side with the geophysical logs, lithofacies, core recovery, formations (including the horizons within the Potomac Formation), and geologic age. Paleosol development indicated by orange (weak) and red (mature). 
The data set for the Fort Mott location included geophysical logs and core descriptions (Miller, et al., 2007). The stratigraphic sequence in this borehole from top to bottom is the Cape May Formation, Englishtown Formation, the Woodbury Formation, the Merchantville Formation, the Cheesequake Formation, the Magothy Formation, and the Potomac Formation. The Potomac Formation begins at $141 \mathrm{ft}$, directly underlying the Magothy Formation.

Environmental interpretations of the muds were made based on color descriptions. These are shown in Figure 3.6 by the orange, representing soils and paleosols beds, and dark red, indicating moderate to well-developed overbank deposits.

The top of Potomac A is interpreted as being $141 \mathrm{ft}$ deep and the base of Potomac A at $363 \mathrm{ft}$. This unit is composed of a thick silt and clay section from $141 \mathrm{ft}$ to about $285 \mathrm{ft}$, overlying two sand beds separated by a thin clay bed. The first sand bed is from 285 to $310 \mathrm{ft}$, and the second sand bed from 311 to $363 \mathrm{ft}$. The second sand bed contains laminations of clay.

The unit of Potomac B is interpreted as being from 363 to $599 \mathrm{ft}$. From 363 to $420 \mathrm{ft}$ is a clay bed, overlying a much thicker silt and clay bed from 420 to $560 \mathrm{ft}$ deep. Sand with lignite is the composition of the lower most bed of this unit, extending from 560 to $599 \mathrm{ft}$.

The unit of Potomac C is interpreted as being from $599 \mathrm{ft}$ to the base of this borehole at $820 \mathrm{ft}$ deep. This unit is very silt rich throughout. The top of the unit is 
made up of mixed silt and clay bed, followed by a predominantly clay bed. The lowest $100 \mathrm{ft}$ of this section are dominated by silt, with lesser fractions of sand or clay. 


\section{Eb33-57 Summit Marina}

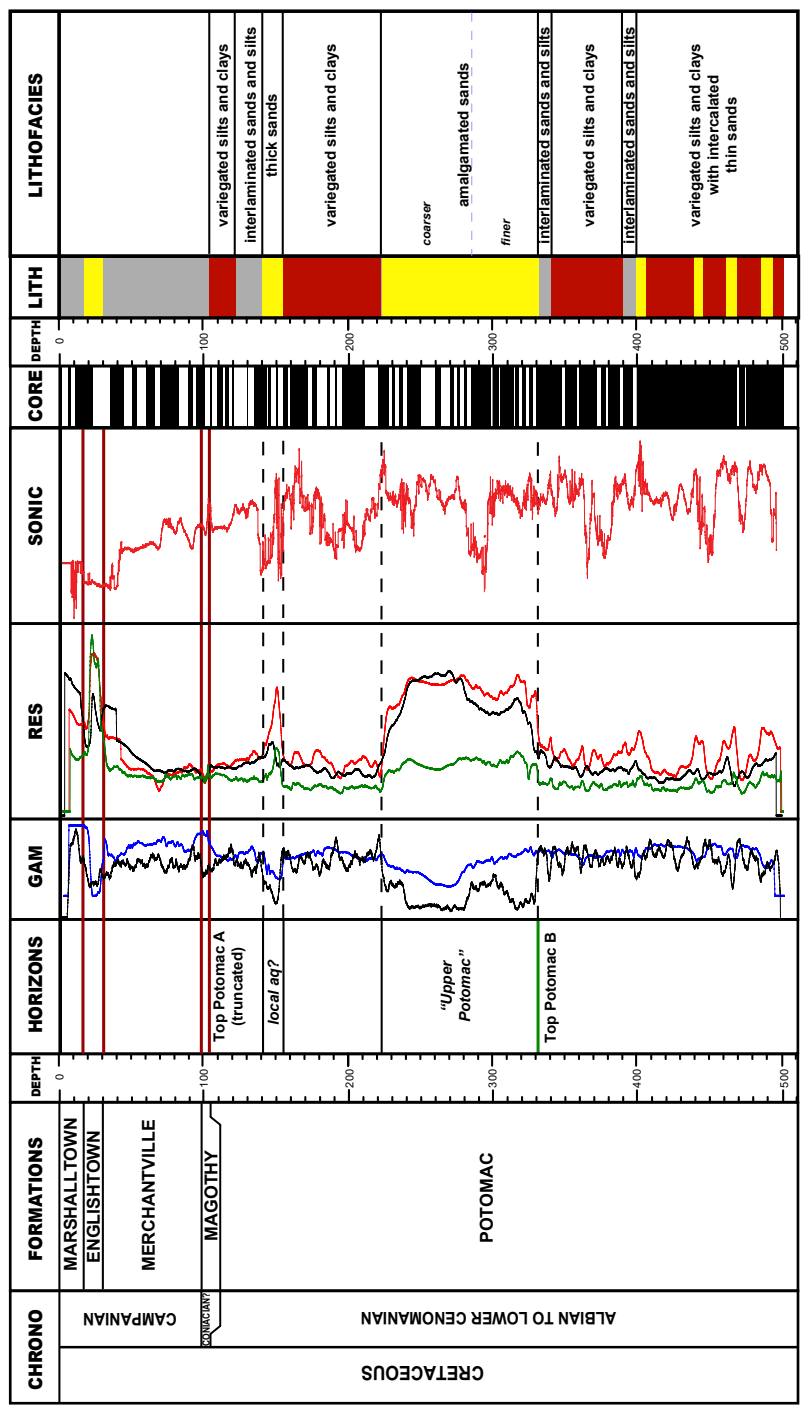

Figure 3.7 The data for the Summit Marina borehole is shown here side by side with the geophysical logs, lithofacies, core recovery, formations (including the horizons within the Potomac Formation), and geologic age. Figure from McLaughlin, 2012. 
The data set compiled for lithologic interpretations of the Summit Marina location is composed of geophysical logs and core examined and described in previous studies. The sequence of formations from top to bottom in this core are as follows; Marshalltown, Englishtown, Merchantville, Magothy, and Potomac.

The top of Potomac A lies at roughly $105 \mathrm{ft}$ deep. The upper parts of this unit are dominated by silt and clays with thin sand packages scattered within. One roughly $15 \mathrm{ft}$ thick sand package at $150 \mathrm{ft}$ depth, which is labeled as a "local aquifer?" is within this clay and silt rich zone. The lower half of Potomac A is made up of amalgamated sands and is roughly $105 \mathrm{ft}$ thick. This large sand package transitions from coarse grained to finer grained lower in the section.

The top of Potomac B lies roughly $332 \mathrm{ft}$ deep. Interlaminated sands and silts, and variegated silts and clays make up the first roughly $70 \mathrm{ft}$ of this section. The lower roughly $100 \mathrm{ft}$ of this section is made up of variegated silts and clays with interlaminated thin sands. These are silt and clay beds that alternate with thin sand beds every 10 to 15 feet. The borehole ends is completed in the Potomac B unit, nit reaching basement. 


\section{Cd51-21 New Castle}

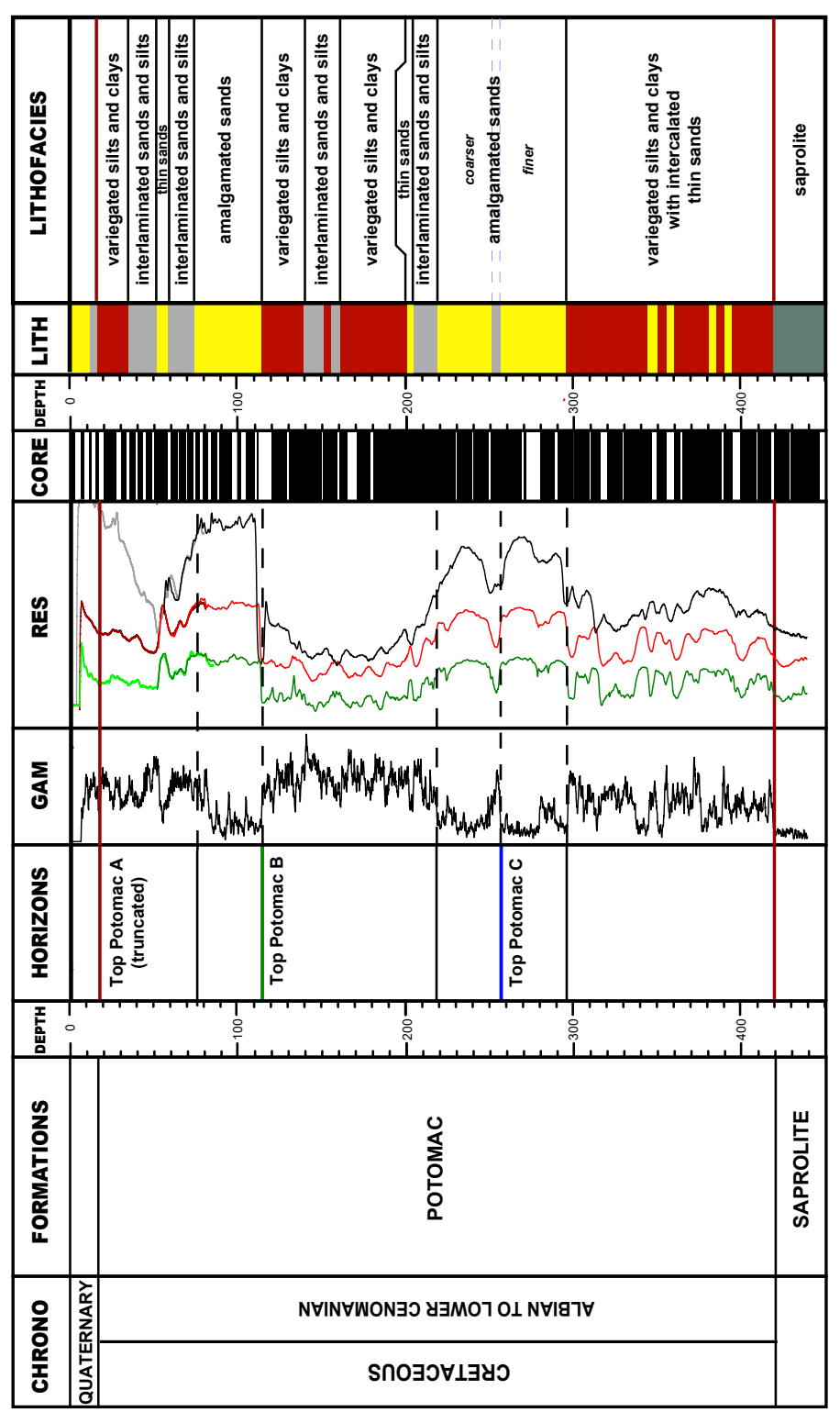

Figure 3.8 The data for the Cd51-21 New Castle borehole is shown here side by side with the geophysical logs, lithofacies, core recovery, formations (including the horizons within the Potomac Formation), and geologic age. Figure from McLaughlin, 2012. 
The data set for the Cd51-21 New Castle location consisted of geophysical logs and core. Quaternary deposits overlie the Potomac Formation, extending to $20 \mathrm{ft}$ deep. This borehole and the other New Castle borehole (Cd51-23) are the basis for the McKenna et al. (2004) lithofacies interpretations. The same facies interpreted here are seen throughout the entire study area.

The top of Potomac A lies at $20 \mathrm{ft}$ in depth, extending to roughly $115 \mathrm{ft}$ in depth. The upper half of this section is composed mainly of interlaminated sands and silt, and variegated silts and clays. A thin sand bed lies from 50 to $60 \mathrm{ft}$ deep. An amalgamated sand package makes up the lower half of Potomac A from 75 to $115 \mathrm{ft}$ deep. This is represented by an overall blocky character in the geophysical logs.

The top of Potomac B lies at $115 \mathrm{ft}$ in depth, extending to $255 \mathrm{ft}$ in depth. Large beds of variegated silts and clays make up the majority of this unit. Thin interlaminated silts and clays are intermixed within these larger silt and clay beds. The base of this unit is made up of a $75 \mathrm{ft}$ thick amalgamated sand interval. This deposit appears in the logs as a blocky pattern. The upper $40 \mathrm{ft}$ of this amalgamated sand bed is considered Potomac $\mathrm{B}$, and the lower $35 \mathrm{ft}$ are Potomac $\mathrm{C}$.

From $255 \mathrm{ft}$ to the saprolite at $420 \mathrm{ft}$ lies Potomac unit C. As previously stated, the first $35 \mathrm{ft}$ are amalgamated sand. The sand that is considered Potomac $\mathrm{C}$ is finer than the sands considered Potomac B. The lower $85 \mathrm{ft}$ of Potomac $\mathrm{C}$ is made up of variegated silts and clays with intercalated thin sands. 


\section{Cd51-23 New Castle}

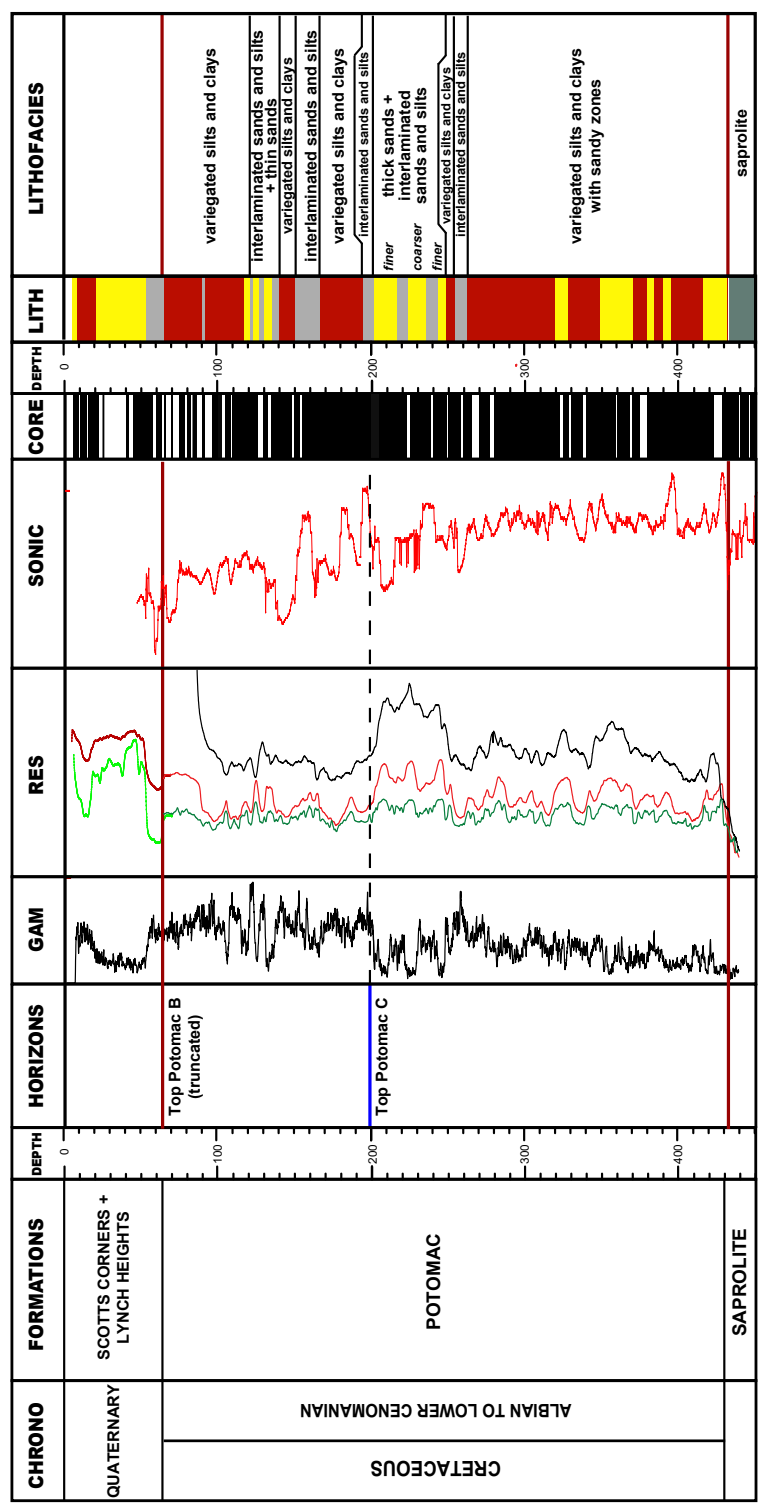

Figure 3.9 The data for the Cd51-23 borehole is shown here side by side with the geophysical logs, lithofacies, core recovery, formations (including the horizons within the Potomac Formation), and geologic age. Figure from McLaughlin, 2012. 
The data set for the Cd51-23 New Castle borehole consists of geophysical logs and core. At this location, the Potomac Formation underlies the Quaternary aged deposits of the Scotts Corner Formation and the Lynch Heights Formation. The Potomac Formation starts at $65 \mathrm{ft}$ in depth in this location. The Potomac unit A is not present in this location due to what has been interpreted as truncation.

Potomac unit B lies from $65 \mathrm{ft}$ to $200 \mathrm{ft}$ in depth. The uppermost $50 \mathrm{ft}$ of this unit are variegated silts and clays, followed by $20 \mathrm{ft}$ thick of interlaminated sands and silts, with very thin beds of sand. The lowermost $60 \mathrm{ft}$ of this unit are made up of variegated silts and clays, and interlaminated sands and silts.

The top of Potomac unit $\mathrm{C}$ lies at $200 \mathrm{ft}$, and the base at $430 \mathrm{ft}$ in depth overlying the saprolite in this location. The top $50 \mathrm{ft}$ of this unit is composed of thick sands, and interlaminated sands and silts. The thick sand beds alternate between finer, coarser, and back to finer. After a $10 \mathrm{ft}$ thick layer of variegated silts and clays and a $10 \mathrm{ft}$ thick layer of interlaminated sands and silts, is a roughly $170 \mathrm{ft}$ thick section of variegated silts and clays with sandy mud zones. The sand packages in this lower $170 \mathrm{ft}$ thick zone are much larger than from the top $50 \mathrm{ft}$ of this unit. 


\section{Cross Section Results}

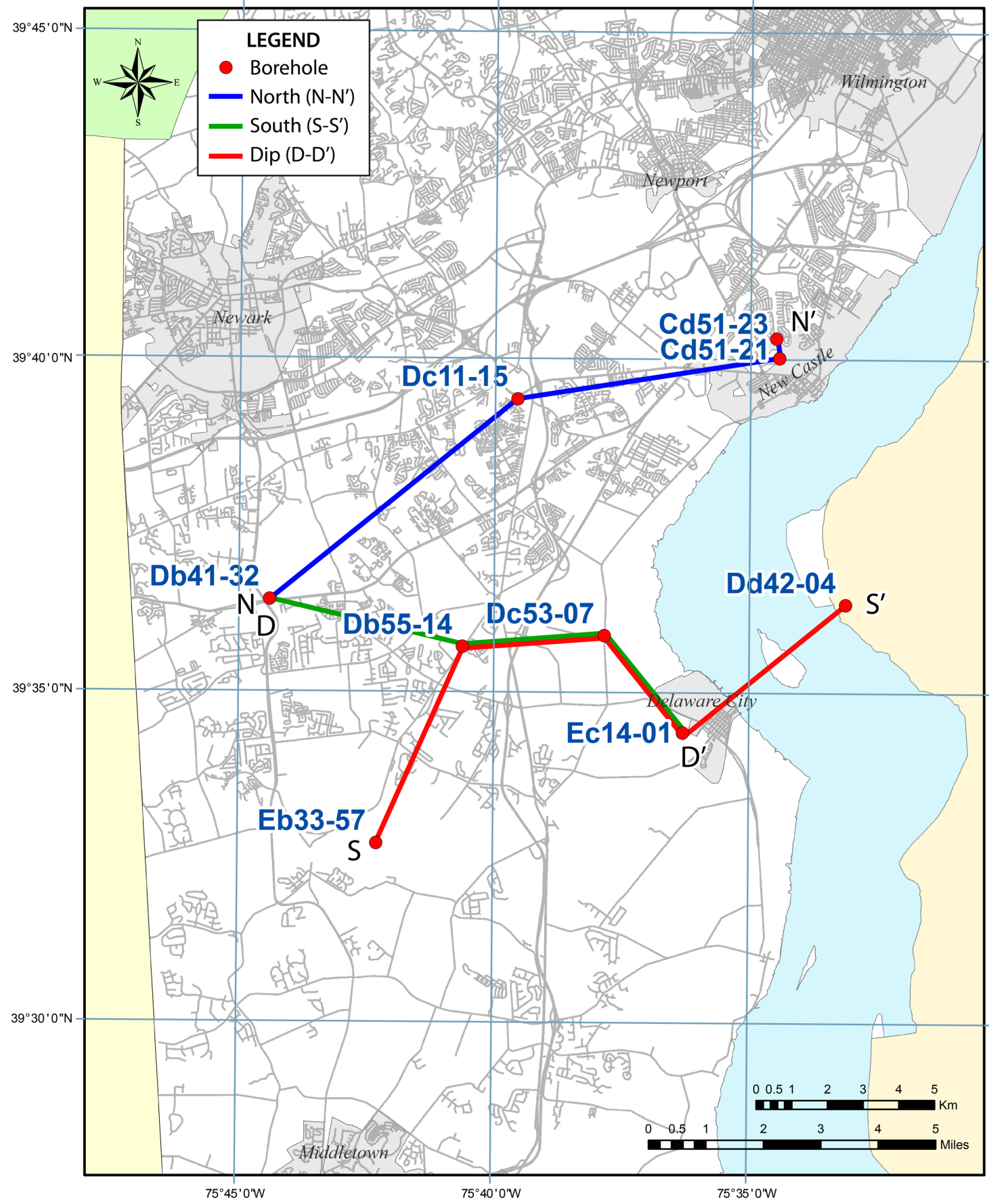

Figure 3.10 Map of the study area with the locations of the nine boreholes, and three cross sections in this study. 


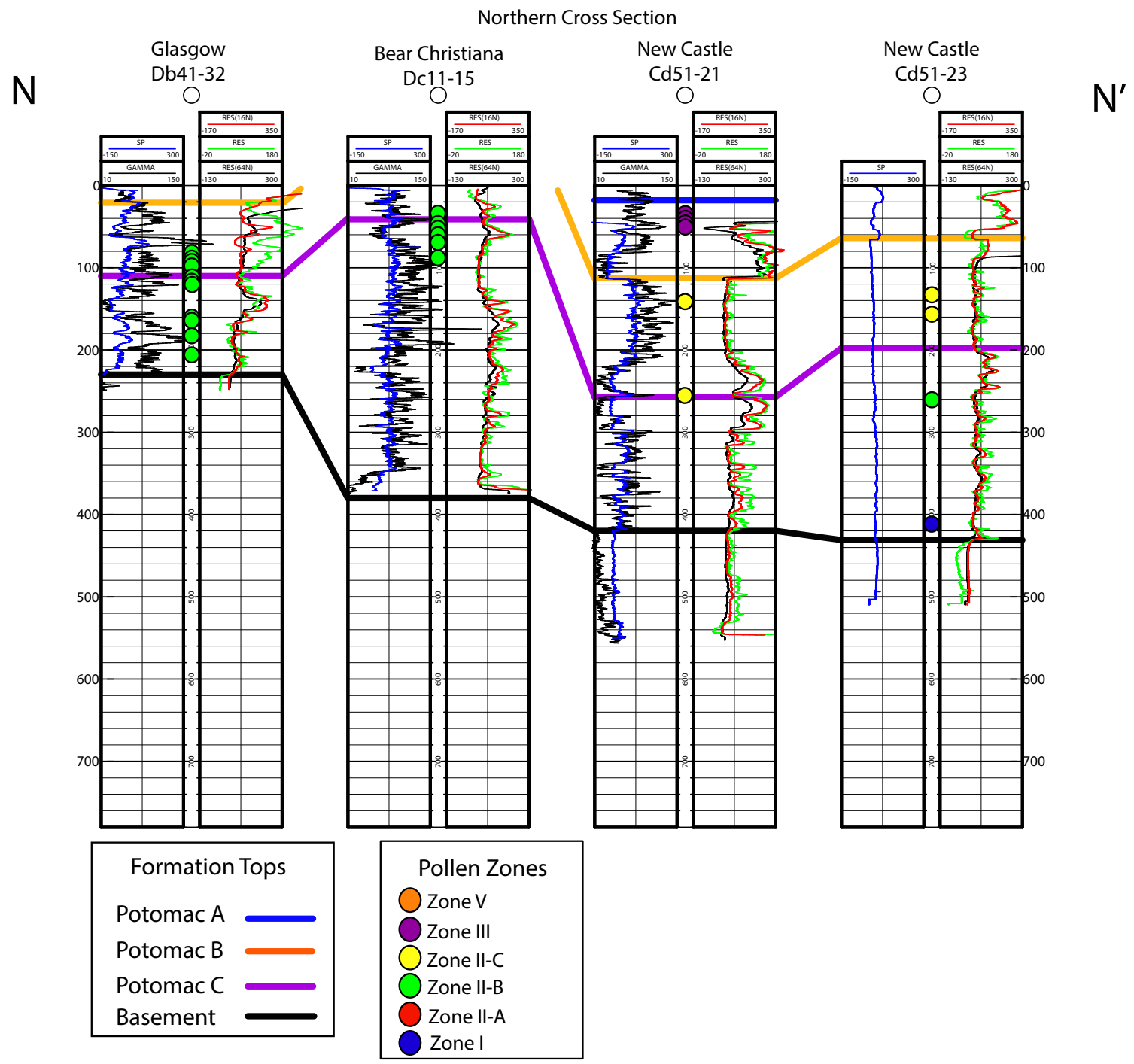

Figure 3.11 Cross section of the northern most boreholes used in this study. Tops of each unit of the Potomac Formation are highlighted, as well as the depth and interpreted zone of the pollen. 


\section{Northern Cross Section}

Potomac A is only present in one of the four boreholes that make up the northern cross section. Potomac A only extends $20 \mathrm{ft}$ in depth in the New Castle Cd51-21 borehole. The Potomac Formation has been truncated in the northwest result in the absence of Potomac A in three of the four boreholes.

Potomac B is present in three of the four northern cross section boreholes but not present in the Bear/Christiana borehole. This is again due the truncation of the Potomac Formation in the northwest. Potomac B appears to be almost horizontal averaging around $150 \mathrm{ft}$ in thickness. The basement at Bear/Christiana site is most likely a topographical low for the area at $365.3 \mathrm{ft}$. This low-lying site was filled in with older Potomac $\mathrm{C}$ sediments, any units above Potomac $\mathrm{C}$ have been eroded. This was interpreted based on the new palynological data that was collected for this study.

Potomac C follows a similar trend as Potomac B in all of the boreholes in the northern cross section. The unit is slightly thinner in the west at Glasgow and thickest in the east at Cd53-23 borehole, thickening about $130 \mathrm{ft}$. The basement at the Glasgow site is a topographical high, older Potomac sediments were not deposited as easily in this location.

Biostratigraphy was also examined through these cross sections. In the north cross section, the two western most boreholes contain only Zone II-B palynomorphs where pollen-bearing lithologies were recovered. These samples are obtained from throughout Potomac C in Glasgow and Bear/Christiana. The two New Castle

boreholes to the east contain Zone I palynomorphs in the base of Potomac C, Zone II- 
B samples towards the top of Potomac C, Zone II-C samples throughout Potomac B, and zone III samples in Potomac A. 
Southern Cross Section

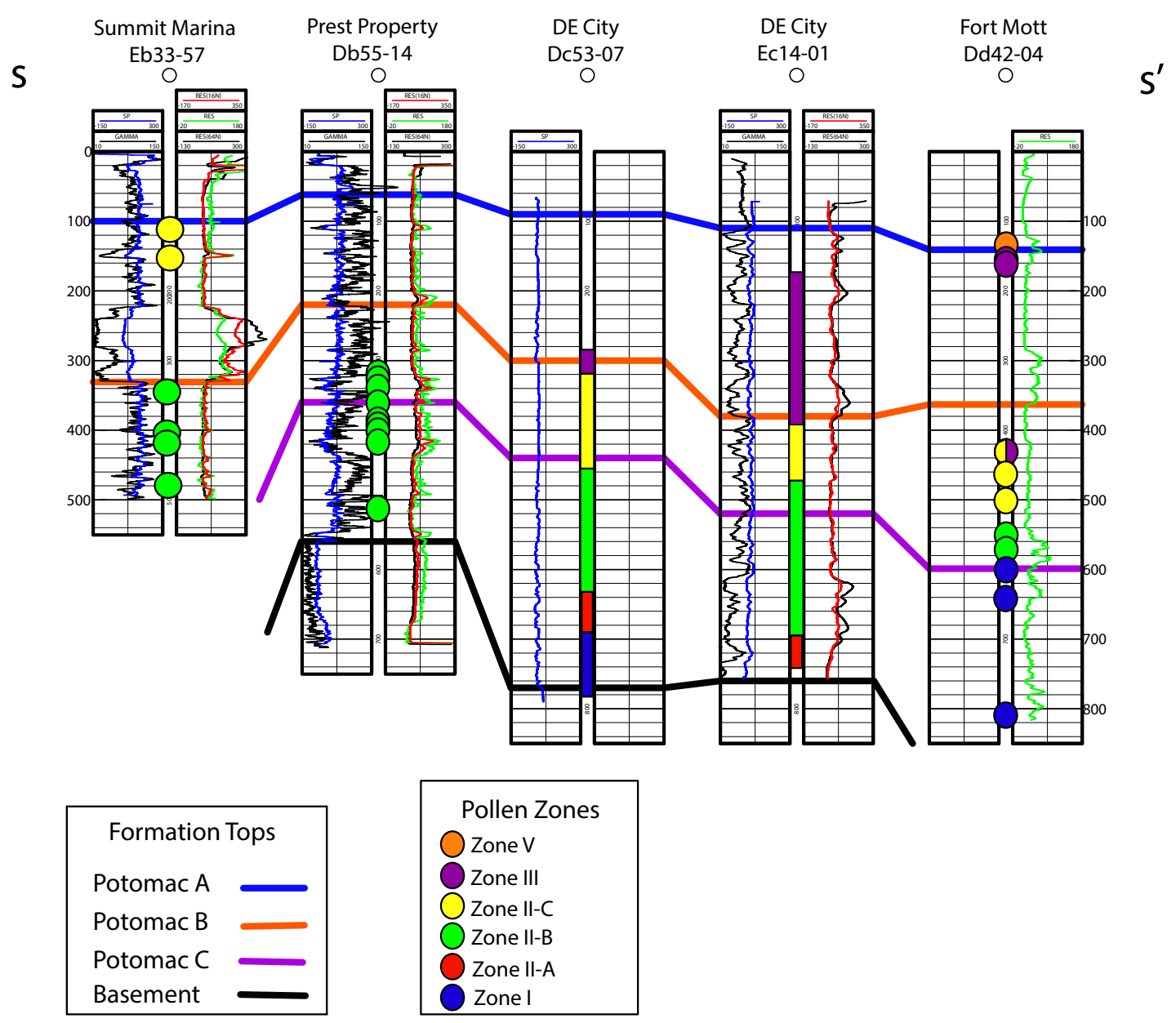

Figure 3.12 Cross section of the southernmost boreholes used in this study. Tops of each unit of the Potomac Formation are highlighted, as well as the depth and interpreted zone of the pollen. 


\section{Southern Cross Section}

Potomac A is present in all five boreholes that make up the southern cross section. The top of Potomac A is around $100 \mathrm{ft}$ in depth in all of the boreholes. The unit slightly thins in the middle but is roughly $200 \mathrm{ft}$ thick in three of the five boreholes. The boreholes of the south cross section contain much more of Potomac A than the northern cross section, this is due to the onlap of the Potomac Formation. Sediments were more capable of being deposited in the southeast of this study area.

Potomac B is also present in all five boreholes of the southern cross section. There is generally uniform thickness throughout the unit of about $250 \mathrm{ft}$. The unit is slightly thicker down dip to the west in the Fort Mott borehole. The top of Potomac B is also the deeper in Fort Mott than in the east at Summit Marina. The Summit Marina borehole does not extend to the base of Potomac B. This is more evidence of onlap in the Potomac Formation. The deeper units are thicker than Potomac A, and the tops of the units are deeper in the south.

Potomac $\mathrm{C}$ shows the most change from east to west, getting thicker and the top becoming deeper from $350 \mathrm{ft}$ in Prest Property to $600 \mathrm{ft}$ in Fort Mott. This trend is result of the onlap of sediments on the basement. The furthest east borehole, Summit Marina, was not drilled deep enough to recover any Potomac $\mathrm{C}$ sediments. The furthest west borehole, Fort Mott, is the deepest borehole used in this study at $830 \mathrm{ft}$ and does not reach the base of Potomac C. 
The biostratigraphy of the southern cross section, many of the same trends as the north were interpreted. Zone I was only interpreted at the base of Dc53-07 Delaware City borehole, Potomac C just above basement. Zone II-A is found in lower Potomac $\mathrm{C}$ in the two Delaware City boreholes, and towards the top of Potomac $\mathrm{C}$ at Fort Mott. All five of the boreholes contain zone II-B samples, Summit Marina towards the top of Potomac A, Prest Property towards the base of Potomac B and throughout Potomac C. The two Delaware City boreholes contain zone II-B palynomorphs towards the top of Potomac C, and Fort Mott at the base of Potomac B. Zone II-C pollen are restricted to Potomac B in the two Delaware City boreholes, as well as Fort Mott. Zone III palynomorphs are identified in Potomac A of the Delaware City boreholes, Fort Mott, and Summit Marina. One sample from the top of Potomac B in the Fort Mott borehole was either II-C or III and is indicated by a half purple and half yellow circle. Zone $\mathrm{V}$ is identified in one sample from the top of Potomac A in the Fort Mott borehole. 


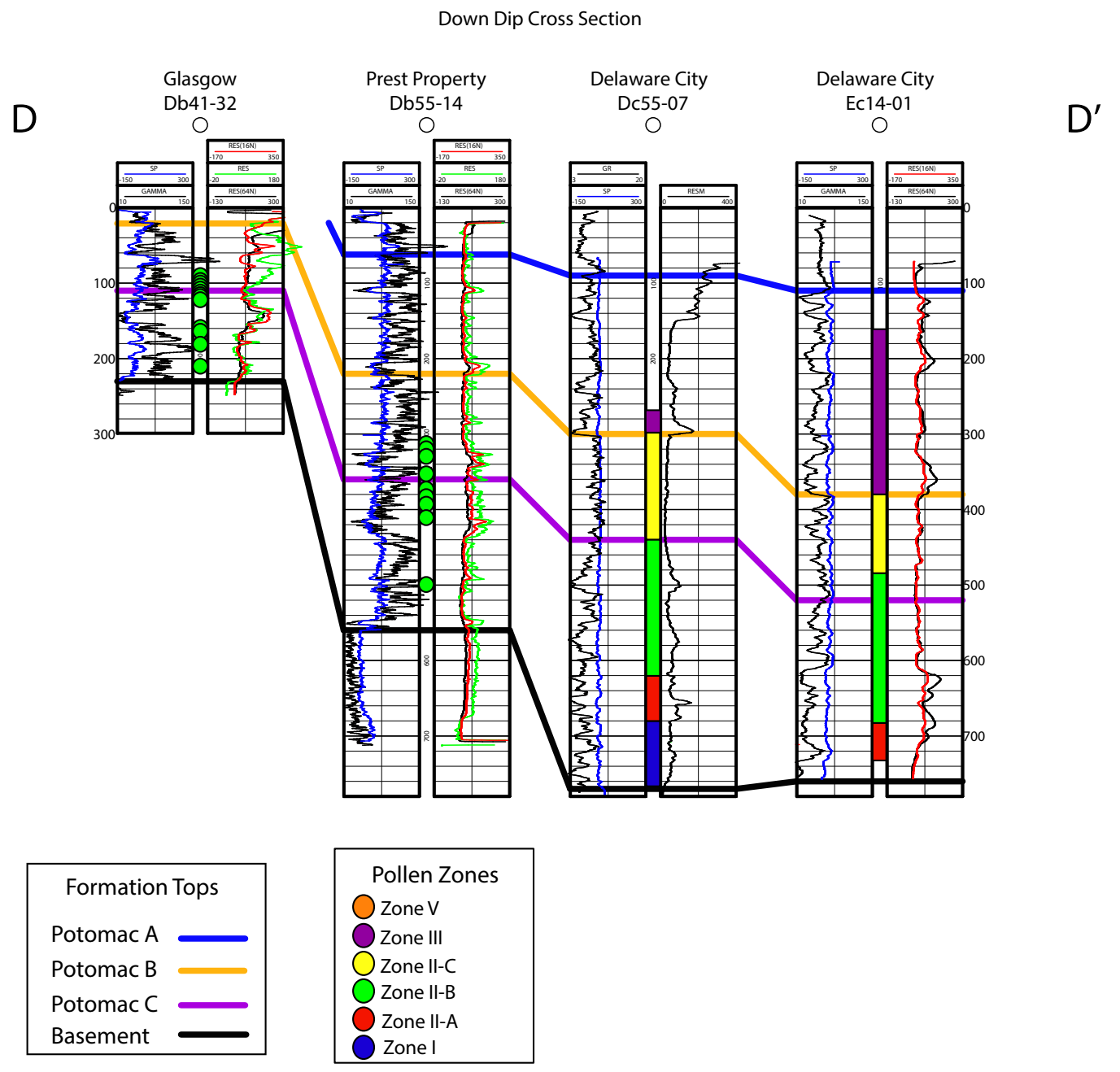

Figure 3.13 Cross section of the boreholes that best represent the down dip trend of the Potomac Formation (for the boreholes used in this study). Tops of each unit of the Potomac Formation are highlighted, as well as the depth and interpreted zone of the pollen. 


\section{Down Dip Cross Section}

The down dip cross section gives the best representation of Potomac Formation from northwest to southeast, onlapping as it gradually thickens and gets deeper towards the southeast. The four boreholes selected show the transition of the Potomac Formation thickening and deepening from northwest to the southeast.

In the furthest west borehole, Glasgow, Potomac A is not recovered. In the next three wells to the east, (Prest Property, Delaware City Dc55-07, Delaware City Ec14-01) the top of Potomac A slightly drops from $65 \mathrm{ft}$ to $105 \mathrm{ft}$. The trend in this layer is a steady thickening from west to east, unrecovered in Glasgow to $370 \mathrm{ft}$ thick in Delaware City Ec14-01. This may be the result of sediment deposit from the Piedmont province when sea level was much lower.

Potomac B shows a similar trend to Potomac A down dip from west to east. The top of the unit gets continuously deeper down dip from $110 \mathrm{ft}$ to $520 \mathrm{ft}$, but stays relatively the same thickness at around $100 \mathrm{ft}$. This is true for all of the boreholes, including Glasgow where Potomac A had not been recovered. This is due to the truncation of the Potomac Formation. The Potomac Formation at the Glasgow site underlies an unconformity and has completely removed Potomac A. The uniform thickness of Potomac B is indicative that as it has not been affected by the unconformity at Glasgow, or if it has the effect was minor.

Potomac $\mathrm{C}$ continues the same trend of getting thicker and deeper down dip to the southeast. At Glasgow, the top of Potomac C is at $110 \mathrm{ft}$ deep and it is $120 \mathrm{ft}$ thick. In the east at Ec14-01 Delaware City the unit starts at $520 \mathrm{ft}$ deep and is $140 \mathrm{ft}$ thick. 
This unit is thickest at the Dc55-07 Delaware City borehole, where it is $330 \mathrm{ft}$ thick. Through the palynological data it is evident that onlapping in Potomac $\mathrm{C}$ has occurred. The lack of palynological Zone I and Zone II-A indicated that the base of Potomac C at Glasgow is not present.

The down dip cross section contains data from three boreholes from the southern cross section (Prest Property and the two Delaware City boreholes), and the shallow up dip borehole from Glasgow. This cross section gives perspective of how the palynomorphs correlate with the units of the Potomac Formation as they change down dip. The palynomorph zones closely follow the lithologic interpretations.

\subsection{Palynological Results}

Samples for Glasgow, Bear/Christiana, and Prest Property were processed and examined for palynomorphs. Diversity and abundance of palynomorphs was recorded by first examining each interval and identifying all of the palynomorph species in that sample. Each interval was then scanned again, this time counting 100 palynomorphs, while also counting the number of spheres from the artificial spike. The palynomorphs were broken down into five morphological groups; eudicots, monocots/magnoliids, Classopollis, Araucariacites, bisaccates, inaperturates, and pteridophytes. 


\section{Bear/Christiana Site}

At the Bear/Christiana site, nine intervals were sampled and processed. Of those nine samples, six bore enough palynomorphs to perform a thorough analysis. All palynological group abundance data is presented in Figure 3.14 and Table 3.1.

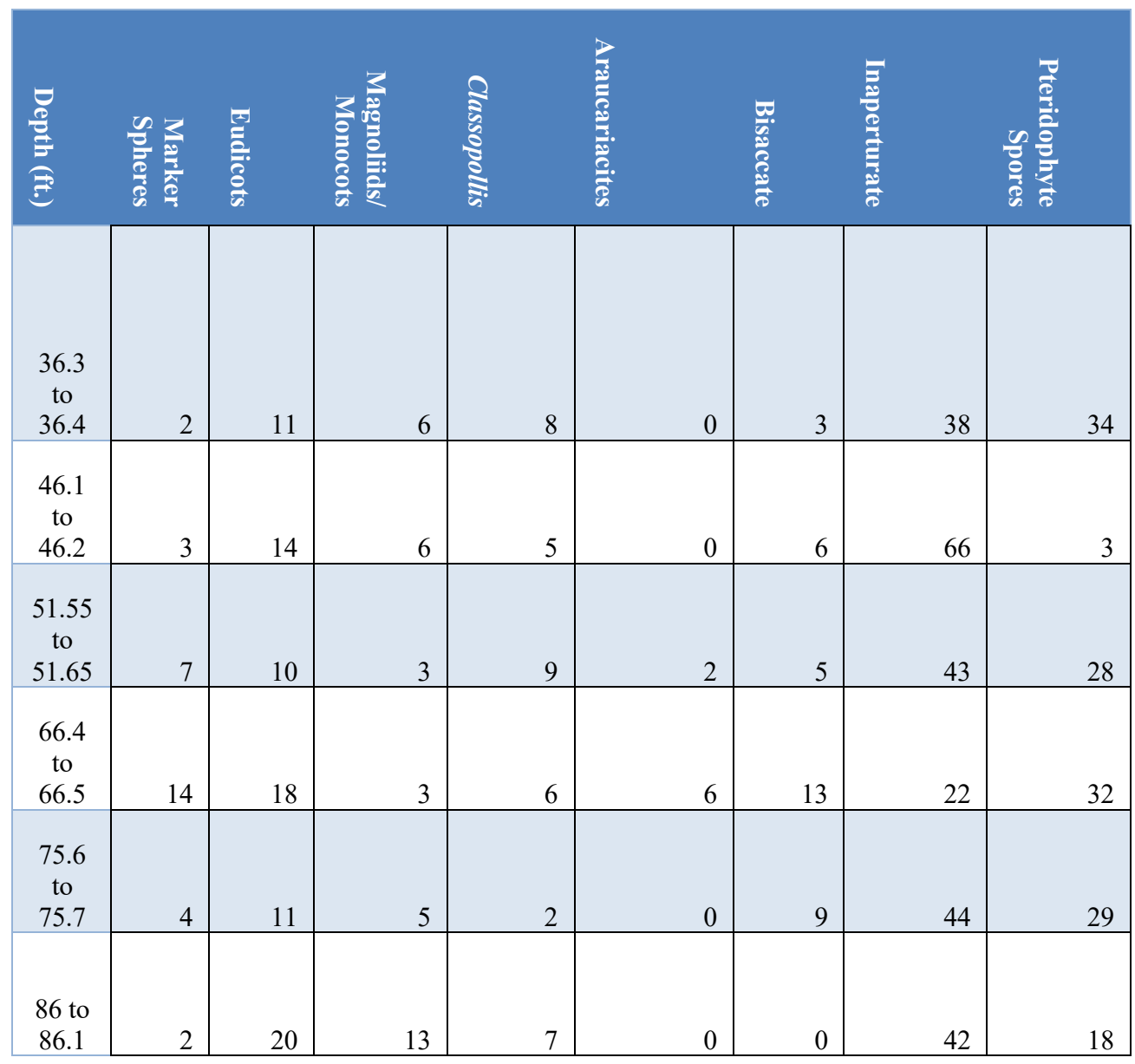

Table 3.1 Depths and percentages of palynomorph abundances in the Bear/Christiana borehole

Based on the species of angiosperm pollen identified within the six samples, it was determined that all of the intervals at the Bear/Christiana site were within pollen 
zone II-B (Doyle and Robbins, 1977). Stratigraphically significant palynomorphs were identified throughout this borehole. Clavatipollenites minutus $(86,75.6,66.4,51.55$, 46.1, and $36.3 \mathrm{ft})$, Tricolpites minutus (86, 66.4, and $46.1 \mathrm{ft})$, Tricolpites pavuluus (aff.) (86 ft), Tricolpites parvuluus (cf.) (36.3 ft), Tricolpites micromunus (86, 75.6, 51.55, $46.1 \mathrm{ft})$, Tricolpites albiensis (aff.) (51.55, $36.3 \mathrm{ft})$, Tricolpites albiensis (cf.) (86, 75.6, $46.1 \mathrm{ft})$, Retitricolpites fragosus (aff.) $(66.4,51.55,36.3 \mathrm{ft})$. These species are identified in Doyle and Robbins (1977) and interpreted at being lower subzone IIB. 


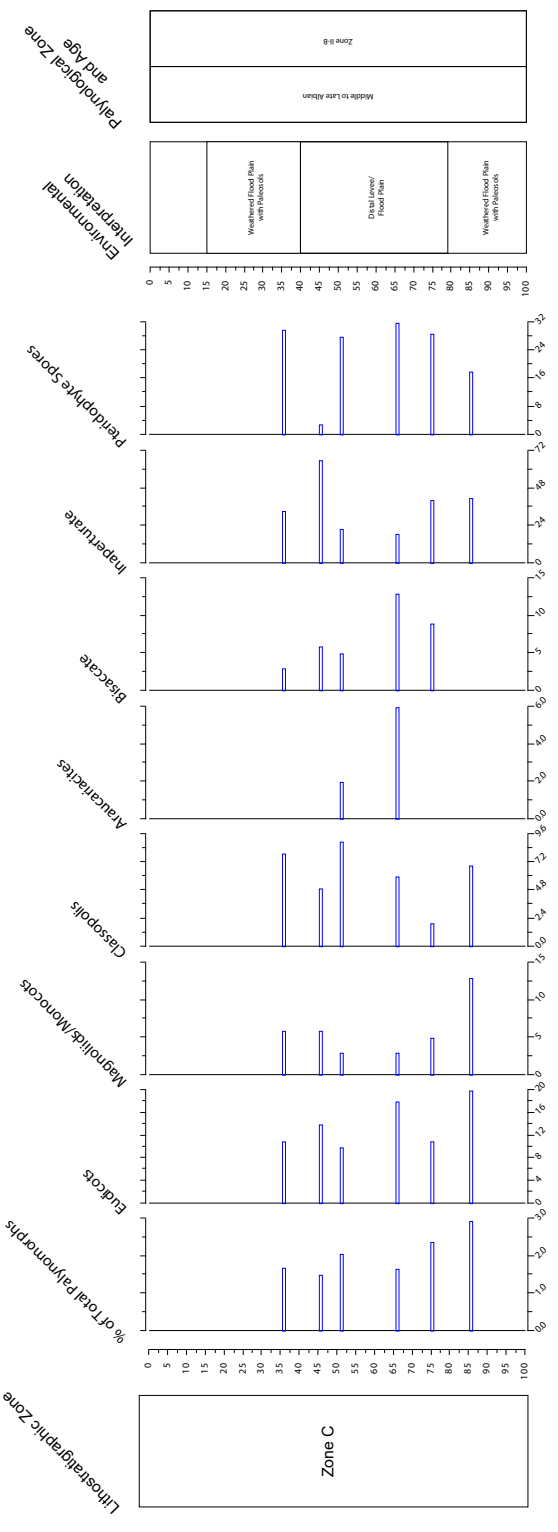

Figure 3.14 Bear/Christiana palynomorph abundances shown side by side with the lithologic, environmental, and chronologic interpretations 
The deepest interval analyzed was 86 to $86.1 \mathrm{ft}$., the number of palynomorphs per gram of sediment was 167,632 . Monocots/magnoliids (13\%) and eudicots $(20 \%)$ reach their highest abundance in this borehole at this interval. The dominant groups are by far the inaperturate $(42 \%)$ and the pteridophytes $(18 \%)$. The breakdown of rest of the palynomorph group abundances for this interval is as follows: $7 \%$ Classopollis, no Araucariacites, no bisaccates.

Moving up in the core, the next analyzed sample was from 75.6 to $75.7 \mathrm{ft}$ in depth. This interval contained far fewer palynomorphs with 67,743 per gram of sediment. Inaperturate (33\%) and pteridophyte (29\%) palynomorphs are once again the dominate group in this interval. The rest of the groups remain in similar concentrations as the previous interval: $18 \%$ eudicots, $9 \%$ monocots/magnoliids, $3 \%$ Classopollis, 2\% Araucariacites, 6\% bisaccates.

At a depth of 66.4 to $66.5 \mathrm{ft}$ the number of palynomorphs per gram of sediment was much lower at 13,585 . The breakdown of palynomorph group abundances for this interval is as follows: $18 \%$ eudicots, $3 \%$ monocots/magnoliids, $6 \%$ Classopollis, $6 \%$ Araucariacites, $13 \%$ bisaccates, $22 \%$ inaperturates, $32 \%$ pteridophytes.

At a depth of 51.55 to $51.65 \mathrm{ft}$ it was calculated that the number of palynomorphs per gram of sediment was 33.484. Eudicots reach their lowest abundance at $10 \%$, and inaperturate (43\%) and pteridophyte $(28 \%)$ continue to be the dominant groups. The breakdown of other palynomorph group abundances for this interval is as follows: 3\% monocots/magnoliids, 9\% Classopollis, 2\% Araucariacites, $5 \%$ bisaccates. 
At a depth of 46.1 to $46.2 \mathrm{ft}$ the number of palynomorphs per gram of sediment was 57,424 . Inaperturate pollen peaks at $66 \%$ in this interval, and pteridophytes are in their lowest abundance by far at 3\%. The breakdown of rest of the palynomorph group abundances for this interval is as follows: $14 \%$ eudicots, $6 \%$ monocots/magnoliids, $5 \%$ Classopollis, no Araucariacites, 6\% bisaccates.

At a depth of 36.3 to $36.4 \mathrm{ft}$ the number of palynomorphs per gram of sediment was 96,500. The overall group abundances are around the averages for this borehole. These are consistent with the trends seen throughout the entirety of this borehole. The breakdown of palynomorph group abundances for this interval is as follows: $11 \%$ eudicots, 6\% monocots/magnoliids, 8\% Classopollis, no Araucariacites, 3\% bisaccates, $38 \%$ inaperturates, $34 \%$ pteridophytes.

Samples were also examined from depths 123.9 to $124 \mathrm{ft}, 61.45$ to $61.55 \mathrm{ft}$, and 43.3 to $43.4 \mathrm{ft}$, but these three samples did not yield enough palynomorphs to describe. 


\section{Glasgow}

At the Glasgow site, 19 intervals were sampled and processed. Of those 19 samples, 11 bore enough palynomorphs to perform a thorough analysis. All data is presented in Figure 3.15 and Table 3.2.

\begin{tabular}{|c|c|c|c|c|c|c|c|c|}
\hline 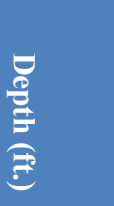 & 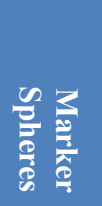 & $\frac{\text { 멓 }}{\frac{8}{8}}$ & 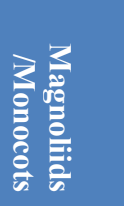 & $\begin{array}{l}2 \\
5 \\
5 \\
\frac{5}{5} \\
5 \\
5 \\
5\end{array}$ & 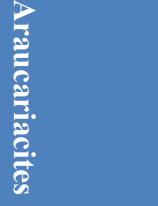 & $\begin{array}{l}\text { ज्: } \\
\text { है } \\
\text { हैं } \\
\text { है }\end{array}$ & 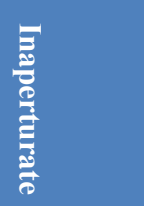 & 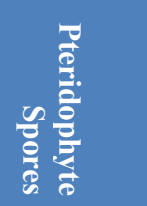 \\
\hline $\begin{array}{c}83.5 \text { to } \\
83.6\end{array}$ & 25 & 24 & 15 & 4 & 5 & 9 & 17 & 26 \\
\hline $\begin{array}{c}89.1 \text { to } \\
89.2\end{array}$ & 5 & 24 & 9 & 12 & 1 & 5 & 33 & 16 \\
\hline $\begin{array}{c}95.1 \text { to } \\
95.2\end{array}$ & 1 & 24 & 11 & 8 & 0 & 10 & 27 & 20 \\
\hline $\begin{array}{l}100.9 \\
\text { to } 101\end{array}$ & 6 & 21 & 16 & 9 & 1 & 7 & 19 & 27 \\
\hline $\begin{array}{c}110.7 \\
\text { to } \\
110.8\end{array}$ & 3 & 26 & 16 & 9 & 0 & 7 & 17 & 25 \\
\hline $\begin{array}{c}117.5 \\
\text { to } \\
117.6\end{array}$ & 2 & 18 & 10 & 6 & 4 & 11 & 27 & 24 \\
\hline $\begin{array}{c}120.2 \\
\text { to } \\
120.3\end{array}$ & 3 & 18 & 14 & 2 & 2 & 8 & 30 & 26 \\
\hline $\begin{array}{c}161.8 \\
\text { to } \\
161.9\end{array}$ & 10 & 32 & 22 & 3 & 2 & 1 & 24 & 16 \\
\hline $\begin{array}{c}165.6 \\
\text { to } \\
165.7\end{array}$ & 8 & 18 & 9 & 3 & 2 & 6 & 33 & 29 \\
\hline $\begin{array}{c}183 \text { to } \\
183.1\end{array}$ & 1 & 17 & 10 & 1 & 0 & 1 & 42 & 29 \\
\hline $\begin{array}{l}210.9 \\
\text { to } 211\end{array}$ & 2 & 19 & 17 & 4 & 1 & 2 & 39 & 18 \\
\hline
\end{tabular}

Table 3.2 Depths and percentages of palynomorph abundances for the Glasgow borehole 
Based on the species of angiosperm pollen identified within the 11 samples, it was determined that all of the intervals at the Glasgow site were within pollen zone IIB (Doyle and robbins, 1977).

Stratigraphically significant Tricolpites crassimurus (aff.) (211 ft, $161.9 \mathrm{ft}, 101$ $\mathrm{ft}, 83.6 \mathrm{ft}$ ), Retitricolpites fragosus (cf.) (211 ft, $110.8 \mathrm{ft}$ ), Tricolpites micromunus (aff. and $c f).(211 \mathrm{ft}, 183.1 \mathrm{ft}, 165.7 \mathrm{ft}, 161.9 \mathrm{ft}, 120.3 \mathrm{ft}, 117.6 \mathrm{ft})$, Clavatipollenites minutus (211 ft, $183.1 \mathrm{ft}, 165.7)$, Tricolpopollenites parvulus $(\mathrm{cf}).(211 \mathrm{ft}, 183.1 \mathrm{ft}$, $165.7 \mathrm{ft})$, and Tricolpites minutus $(211 \mathrm{ft}, 120.3 \mathrm{ft}, 101 \mathrm{ft})$ are present in the samples examined in these cores. According to Doyle and Robbins (1977), these taxa appear near the base of, but mostly in the middle Subzone II-B. 

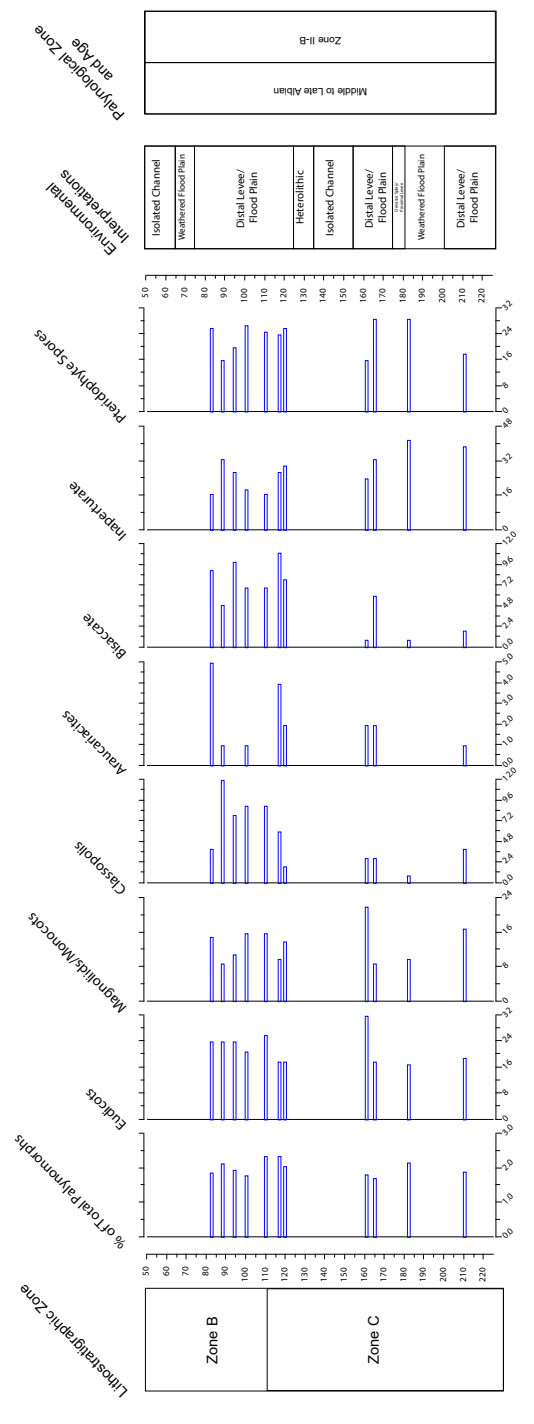

Figure 3.15 Glasgow palynomorph abundances shown side by side with the lithologic, environmental, and chronologic interpretations.

Lithostratigraphic zones are after Benson (2006). 
The deepest interval analyzed was 210.9 to $211 \mathrm{ft}$. The number of palynomorphs per gram of sediment was 109,236. The breakdown of palynomorph group abundances for this interval is as follows: 19\% eudicots, $17 \%$ monocots/magnoliids, 4\% Classopollis, 1\% Araucariacites, 2\% bisaccates, 39\% inaperturates, $18 \%$ pteridophytes.

The sample from 183 to $183.1 \mathrm{ft}$ depth had more abundant palynomorphs, 249,047 per gram of sediment. The breakdown of palynomorph group abundances for this interval is as follows: $17 \%$ eudicots, $10 \%$ monocots/magnoliids, $1 \%$ Classopollis, no Araucariacites, 1\% bisaccates, 42\% inaperturates, 29\% pteridophytes.

Continuing up in the core, the next analyzed sample was from 165.6 to $165.7 \mathrm{ft}$ in depth. There were much fewer palynomorphs in this interval with only 24,609 per gram of sediment. The same overall trends in abundances were seen in this interval as the last.

Palynomorph concentrations are fairly low at 161.8 to $161.9 \mathrm{ft}$, containing 20,851 grains per gram. Eudicot angiosperm pollen reaches a maximum abundance in this sample, making up 32\% of the palynomorph assemblage. Pteridophyrte spore abundances are low at 16\%. Other group abundances are as follows; $22 \%$ monocots/magnoliids, 3\% Classopollis, 2\% Araucariacites, 1\% bisaccates, and 24\% inaperturates.

Palynomorph concentrations are still fairly low at 120.2 to $120.3 \mathrm{ft}$, containing 78,843 per gram of sediment. Inaperturates at $30 \%$, and pteryidophytes at $26 \%$ slightly 
increase, but the overall abundances remain similar, $8 \%$ eudicots, $14 \%$ monocots/magnoliids, 2\% Classopollis, 2\% Araucariacites, 8\% bisaccates.

At a depth of 117.5 to $117.6 \mathrm{ft}$ the number of palynomorphs per gram of sediment was 135,004 , a large increase from the last interval. The breakdown of palynomorph group abundances for this interval is as follows: $18 \%$ eudicots, $10 \%$ monocots/magnoliids, 6\% Classopollis, 4\% Araucariacites, 11\% bisaccates, 27\% inaperturates, $24 \%$ pteridophytes. Abundances remain relatively the same in this sample.

At a depth of 110.7 to $110.8 \mathrm{ft}$ it was calculated that the number of palynomorphs per gram of sediment was 90,002. Eudicots have increased in this interval up $8 \%$, at $26 \%$ overall. Also, monocot/magnoliids have increased now at $16 \%$. The rest of the abundances have seen no major changes or slight decreases accordingly: 9\% Classopollis, no Araucariacites, 7\% bisaccates, 17\% inaperturates, $25 \%$ pteridophytes.

Palynomorph abundances drop once again at 100.9 to $101 \mathrm{ft}$, to 34,430 . Eudicots and monocot/magnoliids are again in high numbers in this interval, $21 \%$ and 16\% respectively. All of the other group abundances are as follows: $9 \%$ Classopollis, 1\% Araucariacites, 7\% bisaccates, 19\% inaperturates, $27 \%$ pteridophytes.

At a depth of 95.1 to $95.2 \mathrm{ft}$ it number of palynomorphs per gram of sediment was much higher at 222,570. A very similar distribution of group abundances was seen in this interval as the last. The breakdown of palynomorph group abundances for 
this interval is as follows: $24 \%$ eudicots, $11 \%$ monocots/magnoliids, $8 \%$ Classopollis, no Araucariacites, $10 \%$ bisaccates, $27 \%$ inaperturates, $20 \%$ pteridophytes.

At a depth of 89.1 to 89.2 the number of palynomorphs per gram of sediment was 49,016. Monocot/magnoliids are at their lowest abundance in this interval at $9 \%$, with inaperturate pollen at one of its highest abundances $33 \%$. The breakdown of palynomorph group abundances for this interval is as follows: $24 \%$ eudicots, $9 \%$ monocots/magnoliids, 12\% Classopollis, 1\% Araucariacites, 5\% bisaccates, 33\% inaperturates, $16 \%$ pteridophytes.

At a depth of 83.5 to $83.6 \mathrm{ft}$ it was calculated that the number of palynomorphs per gram of sediment was 8,604 . The breakdown of palynomorph group abundances for this interval is as follows: $24 \%$ eudicots, $15 \%$ monocots/magnoliids, $4 \%$ Classopollis, 5\% Araucariacites, 9\% bisaccates, 17\% inaperturates, 26\% pteridophytes.

Samples were also examined from depths 228.4 to $228.5 \mathrm{ft}, 193.2$ to $193.3 \mathrm{ft}$, 177.2 to $177.3 \mathrm{ft}, 169.1$ to $169.2 \mathrm{ft}, 106$ to $106.1 \mathrm{ft}, 44.7$ to $44.8 \mathrm{ft}, 38.5$ to $38.6 \mathrm{ft}$, but these eight samples did not yield enough palynomorphs to describe.

\section{Prest Property site}

At the Prest Property site, fifteen intervals were sampled and processed. Of those fifteen samples, nine bore enough palynomorphs to perform a thorough analysis or were relevant to this study. All palynomorph abundance data is presented in Figure 3.16 and Table 3.3 . 


\begin{tabular}{|c|c|c|c|c|c|c|c|c|}
\hline $\begin{array}{l}\stackrel{\theta}{8} \\
\stackrel{8}{E} \\
\stackrel{E}{E}\end{array}$ & 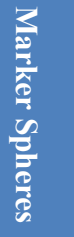 & $\frac{\text { 절 }}{\frac{8}{8}}$ & 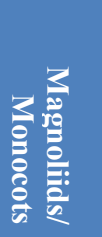 & $\begin{array}{l}ई \\
5 \\
\frac{5}{8} \\
5 \\
\vdots \\
\vdots\end{array}$ & 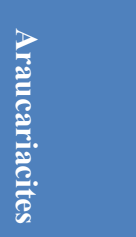 & $\begin{array}{l}\text { ㅁ. } \\
\text { है } \\
\text { है } \\
\frac{0}{0}\end{array}$ & 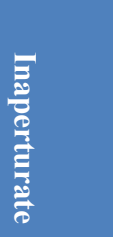 & 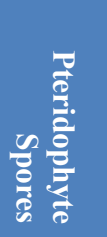 \\
\hline $\begin{array}{c}307.2 \\
\text { to } \\
307.3\end{array}$ & 3 & 25 & 5 & 14 & 0 & 2 & 20 & 34 \\
\hline $\begin{array}{c}316.8 \\
\text { to } \\
316.9\end{array}$ & 68 & 24 & 7 & 2 & 0 & 0 & 21 & 46 \\
\hline $\begin{array}{c}333.6 \\
\text { to } \\
333.7\end{array}$ & 3 & 17 & 6 & 7 & 2 & 0 & 32 & 36 \\
\hline $\begin{array}{c}354.3 \\
\text { to } \\
354.4\end{array}$ & 4 & 13 & 5 & 6 & 3 & 1 & 20 & 52 \\
\hline $\begin{array}{c}373.4 \\
\text { to } \\
373.5\end{array}$ & 197 & 31 & 0 & 0 & 0 & 0 & 6 & 63 \\
\hline $\begin{array}{c}382.85 \\
\text { to } \\
382.95\end{array}$ & 1 & 12 & 5 & 6 & 2 & 2 & 50 & 23 \\
\hline $\begin{array}{c}395.4 \\
\text { to } \\
395.5\end{array}$ & 8 & 9 & 7 & 4 & 0 & 2 & 28 & 50 \\
\hline $\begin{array}{c}411.6 \\
\text { to } \\
411.7\end{array}$ & 17 & 8 & 3 & 6 & 2 & 2 & 47 & 32 \\
\hline $\begin{array}{l}501.9 \\
\text { to } 502\end{array}$ & 17 & 9 & 6 & 3 & 2 & 7 & 27 & 46 \\
\hline
\end{tabular}

Table 3.3 Depths and percentages of palynomorphs abundances in the Prest Property borehole 
Based on the species of angiosperm pollen identified within the nine samples, it was determined that all of the intervals at the Prest Property site were within pollen zone II-B (Doyle and Robbins, 1977). A possible transition occurs towards the top of intervals sampled from middle II-B to upper II-B. The stratigraphically significant species are Tricolpites albiensis (aff.) (501.9, 354.3, 333.6, $316.8 \mathrm{ft})$, Tricolpites micromunus (aff.) (382.85 ft), Tricolpites albiensis (cf.) (307.2 ft), Tricolpopollenites parvulus (cf.) (333.6, $316.8 \mathrm{ft})$, Retitricolpites fragosus (aff.) (395.4), Clavatipollenites minutus (501.9, 411.6, 382.85, 373.4, 354.3, 333.6, $316.8 \mathrm{ft})$, Tricolpites minutus (501.9, 395.4, 354.3, 333.6, 307.2 ft), Retitricolpites magnificus (cf.) (307.2 ft), Tricolpites micromunus (cf.) (333.6, 316.8, $307.2 \mathrm{ft})$. 


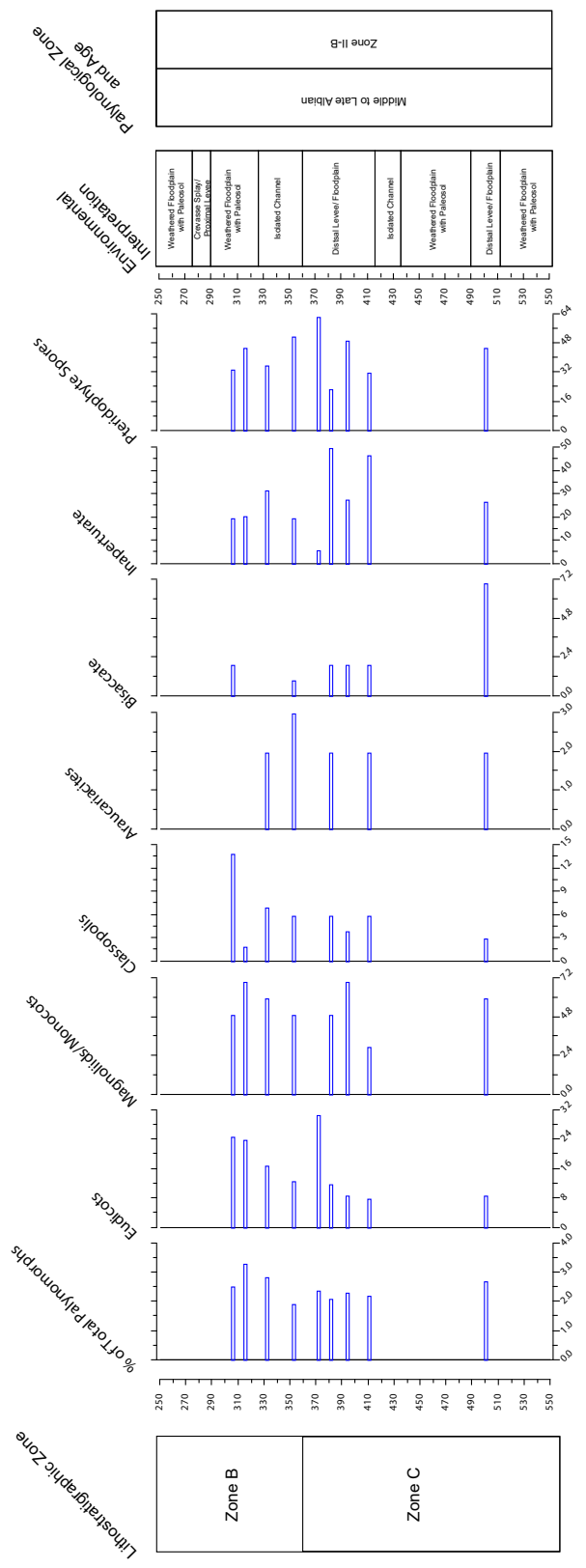

Figure 3.16 Prest Property palynomorph abundances shown side by side with the lithologic, environmental, and chronologic interpretation 
The deepest interval analyzed was 501.9 to $502 \mathrm{ft}$. It was calculated that the number of palynomorphs per gram of sediment was 18,325. Eudicot abundances are low at $9 \%$. The breakdown of the palynomorph group abundances for this interval is as follows: $6 \%$ monocots/magnoliids, 3\% Classopollis, 2\% Araucariacites, $7 \%$ bisaccates, $27 \%$ inaperturates, $46 \%$ pteridophytes.

Moving up in the core, the next analyzed sample was from 411.6 to $411.7 \mathrm{ft}$ in depth, with the number of palynomorphs per gram of sediment at 14,947. Eudicots (8\%) and monocot/magnoliid (3\%) abundances remain low in this interval. At 47\%, inaperturate are the most abundant group. The breakdown of the rest of the palynomorph group abundances for this interval is as follows: $6 \%$ Classopollis, $2 \%$ Araucariacites, $2 \%$ bisaccates, $32 \%$ pteridophytes.

At a depth of 395.4 to $395.5 \mathrm{ft}$ the number of palynomorphs per gram of sediment was 33,402 . This is the last interval before the eudicot pollen ( $9 \%$ ) begin to increase in abundance. At 50\%, pteridophytes are by far the most abundant group. The breakdown of the rest of the palynomorph group abundances for this interval is as follows: 7\% monocots/magnoliids, 4\% Classopollis, no Araucariacites, 2\% bisaccates, $28 \%$ inaperturates.

At a depth of 382.85 to $382.95 \mathrm{ft}$ it was calculated that the number of palynomorphs per gram of sediment was 243,405 . Eudicot pollen begins to increase at $12 \%$ and inaperturate pollen reach their peak in this interval at $50 \%$. The breakdown of the other palynomorph group abundances for this interval is as follows: $5 \%$ 
monocots/magnoliids, 6\% Classopollis, 2\% Araucariacites, 2\% bisaccates, $23 \%$ pteridophytes.

At a depth of 373.4 to $373.5 \mathrm{ft}$ the number of palynomorphs per gram of sediment dropped to 1,395. Monocot/magnoliids, Classopollis, Araucariacites, and bisaccates are not present in this interval. Eudicots continue to increase in abundance up to $31 \%$. The breakdown of palynomorph group abundances for this interval is as follows: $6 \%$ inaperturates, $63 \%$ pteridophytes.

At a depth of 354.3 to $354.4 \mathrm{ft}$ the number of palynomorphs per gram of sediment was 55,784. Pteridophytes make up more than half of the overall abundance at $52 \%$. Bisaccate pollen is present, just at $1 \%$ of the total palynomorph count. The breakdown of palynomorph group abundances for this interval is as follows: $13 \%$ eudicots, 5\% monocots/magnoliids, $6 \%$ Classopollis, 3\% Araucariacites, $20 \%$ inaperturates.

At a depth of 333.6 to $333.7 \mathrm{ft}$ it was calculated that the number of palynomorphs per gram of sediment was 108,311. Eudicot pollen (17\%) is once again more abundant in this interval than in the lowest four intervals. The rest of the palynomorph groups are present in their relative average abundances. The breakdown of other palynomorph group abundances for this interval is as follows: $6 \%$ monocots/magnoliids, 7\% Classopollis, 2\% Araucariacites, no bisaccates, 32\% inaperturates, $36 \%$ pteridophytes.

At a depth of 316.8 to $316.9 \mathrm{ft}$ it was calculated that the number of palynomorphs per gram of sediment was low at 5,592. Eudicots see a spike in 
abundance with 24\%. Araucariacites and bisaccates are not present in this interval. The breakdown of palynomorph group abundances for this interval is as follows: $24 \%$ eudicots, 7\% monocots/magnoliids, 2\% Classopollis, 21\% inaperturates, $46 \%$ pteridophytes.

At a depth of 307.2 to $307.3 \mathrm{ft}$ the number of palynomorphs per gram of sediment was 96,894 . Eudicot pollen is again high at $25 \%$ in this interval. The breakdown of palynomorph group abundances for this interval is as follows: $5 \%$ monocots/magnoliids, 14\% Classopollis, no Araucariacites, 2\% bisaccates, 20\% inaperturates, $34 \%$ pteridophytes. 


\section{Chapter 4 \\ DISCUSSION}

\subsection{Lithofacies and Depositional Environments}

The five lithofacies interpreted in the McKenna, et al. (2004) poster on

Potomac sedimentology will be the basis for environmental interpretations for this study. These five environments that make up the Potomac Formation are amalgamated

channels, isolated channels, crevasse splay/proximal levee, distal levee/flood plain, and weathered flood plain with paleosols. These lithofacies are identified and depositional environments are interpreted in the boreholes examined as part of this study. 


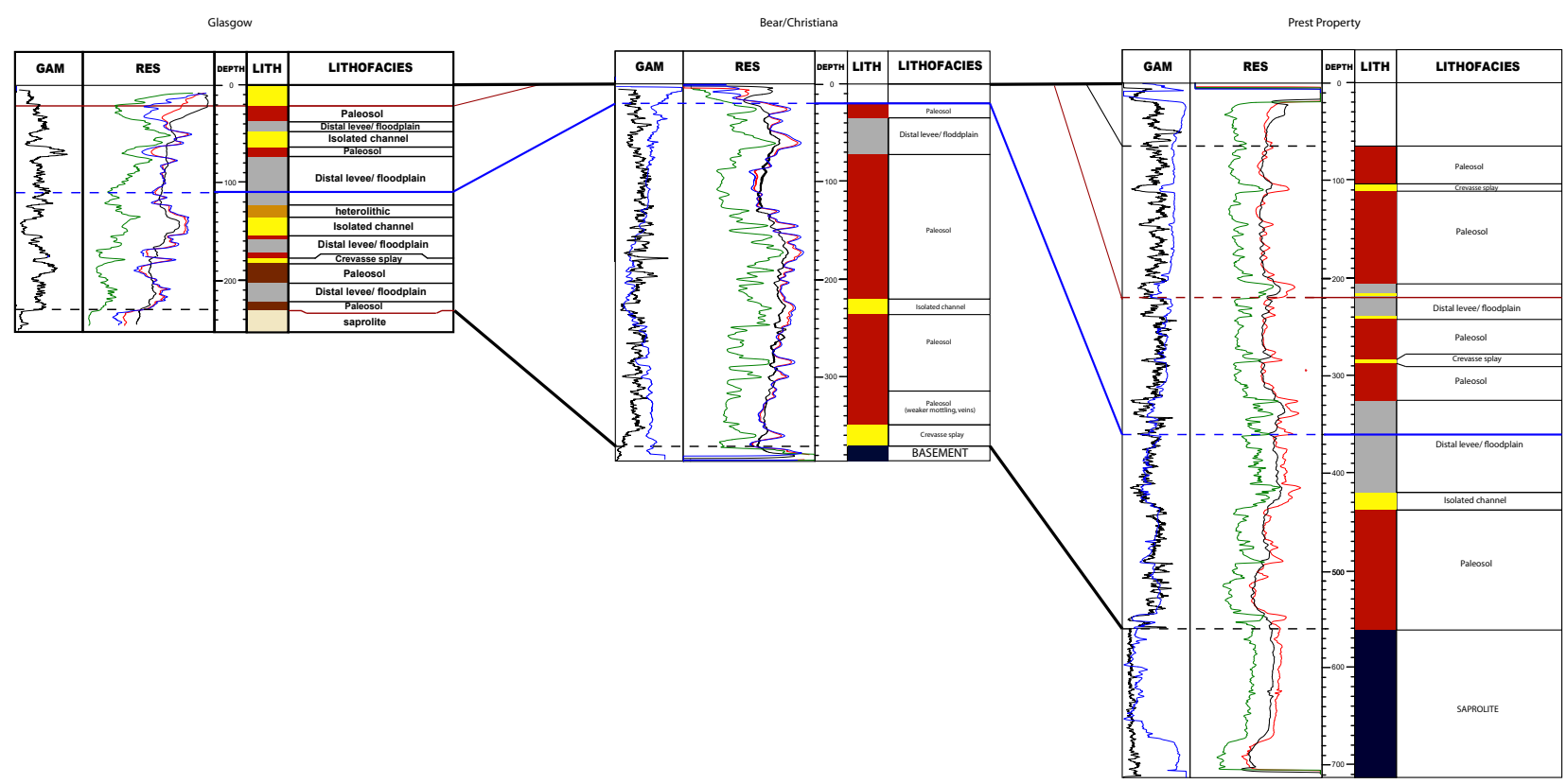

Figure 4.1 Correlation of the interpreted depositional environments of the three newly examined boreholes 


\section{Bear/Christiana}

The lithologic interpretations of the core recovered from the Bear/Christiana borehole can be found in Figure 3.1.

From basement at 365 to $350 \mathrm{ft}$, there was not much of the core recovered. The recovered sediment was made up of quartz pebbles and gravels, with a small percentage of sands and clays. This could be the result of ancient Potomac river system eroding the metamorphic basement carrying large sediments from regions updip on the basement rock.

The section from 350 to $315 \mathrm{ft}$.is composed of mottled silts and clay, which is interpreted as a gray to light red, weathered flood plain/paleosol. This section is weakly mottled and contains cracks throughout. This is indicative of a weak to moderately developed soil with vegetation (Thornburg, 2016).

The interval of 315 to $235 \mathrm{ft}$ is interpreted as another gray to red weathered flood plain/paleosol. The high clay content, as well as mottling are indicative of weathered flood plain and paleosol environments. Some thin sand beds are scattered throughout this large package, although they do not appear in enough frequency or thickness to indicate a change in environment.

From 235 to $220 \mathrm{ft}$ is interpreted as an isolated channel environment. This thick sand package contains gravels at the base, fining upward to very fine sand. This layer is very poorly sorted, indicating a change in energy throughout its depositional 
history. Gravels would indicate a higher energy channel that has transitioned to lower energy when the fine sands were deposited.

From 220 to $208 \mathrm{ft}$ is interpreted as a weathered flood plain/ paleosol layer. This interpretation is based on the presence of siderite within a brown, gray, and red clay layer.

A thick interlaminated sand and silt bed from 208 to $124 \mathrm{ft}$ is interpreted as a distal levee/flood plain environment. This heterogeneous section was interpreted as floodplain due to the irregularity of the log pattern and the range of sediment types. This section contains some mottled clay sections, but the overall trend is a pattern of consistently alternating thin sand beds and silt rich layers. The clays are mostly gray and red with few purple sections, this indicates a very weak to moderately developed soil. The clays do not seem to be prevalent enough to warrant a change in the depositional environment, instead they are interpreted as being part of the flood plain.

The overlying layer is another section of interpreted weathered flood plain with paleosols from 124 to $58 \mathrm{ft}$. The clay and silts in this section are heavily mottled and with some banding. These structures, as well as the color, match the descriptions given by McKenna, et al. (2004) for this environment.

The next environment interpreted in this core is from 58 to $36 \mathrm{ft}$ deep is distal levee/flood plain. This is based on the thin interlaminated sand and silts. Root traces, crossbedding, and charcoal fragments also support this interpretation. 
The top $20 \mathrm{ft}$ of Potomac sediments in the Bear/Christiana borehole are interpreted as weathered flood plain with paleosols. This environmental interpretation is based on the red and gray color, and the high amount of silt and clay.

\section{Prest Property:}

Lithologic interpretations and geophysical logs for this borehole can be found in Figure 3.2.

From 564.1 to $438.2 \mathrm{ft}$ is a mottled clay and silt section interpreted as a weathered flood plain with paleosols. Banding and mottling are frequent throughout this section. The majority of this section is made of clay, with sphaerosiderite nodules abundant in zones. These are all characteristics of a weathered flood plain with paleosols.

A thick sand package is interpreted as an isolated channel from 438.2 to 420.9 $\mathrm{ft}$. Lots of organic debris is present in this section. This sand is not very clean and likely not well suited as an aquifer.

From 420.9 to $324.7 \mathrm{ft}$ is a layer of interlaminated sand and silts. Layers within the section are very silty with thin intermittent beds of sand. This is interpreted as a distal levee/ flood plain environment of deposition. This section transitions between sandier and siltier zones but is consistently dominated by one of these two lithologies.

A thin sand layer from 287.3 to $284.2 \mathrm{ft}$ is interpreted as a crevasse splay/ proximal levee. The sand alternates between clean and muddy layers, possibly 
indicating a changing environments or short periods of soil formation over sand deposits between depositional events.

From 324.7 to $287.3 \mathrm{ft}$ is a mottled silts and clays layer which is interpreted as a weathered flood plain and paleosol. This layer is mostly made up of clays and silts, with few thin sand sections. Mottling and laminations within the section are common. The red and gray mottles are also consistent with that of a paleosol.

From 284.2 to $241 \mathrm{ft}$ is a mottled paleosol layer. This layer is mostly homogenous throughout, showing all of the typical characteristics of a paleosol. The colors range all within the descriptions of a typical paleosol, as well as the lithologies.

From 241 to $206.5 \mathrm{ft}$ are interbedded sand and silt layers interpreted as distal levee/ flood plain environment of deposition. The beds are thin and full of black grain such as charcoal fragments and opaque heavy minerals (OHM). These are characteristic of an environment with infrequent deposition due to flooding of a river.

From 206.5 to $111.9 \mathrm{ft}$ is a layer of mottled silts and clays interpreted as a weathered flood plain with paleosols. Banded and heavily mottled clay sections are the dominant lithology, silt rich sections are also prevalent. The colors range from reddish gray, olive gray, and weak red; all of these shades are indicative of very weakly developed paleosols (Thornburg, 2016).

From 111.9 to $105.8 \mathrm{ft}$ is a thin sand bed indicating a crevasse splay/ proximal levee environment of deposition. This was determined based on the charcoal fragments and thickness of the bed. 
The next bed of the Potomac Formation at this site extends to the Merchantville Formation from 105.8 to $61.75 \mathrm{ft}$. This bed was thick red, and light gray clay interpreted as a weathered flood plain/ paleosols. The colors of this bed indicate that it is a very weakly developed paleosol (Thornburg, 2016). Mottling is frequent in the base of the section, this is not seen higher in the section. This is possibly due to the base of the section being further on the flood plain and more fluvial influences in the upper section.

\section{Glasgow}

Lithologic interpretations for this borehole can be found in Figure 3.3.

The deepest identified section of the Potomac Formation at the Glasgow site was an eight-foot layer of dark variegated silts and clays starting at $230 \mathrm{ft}$, sitting on a saprolite basement. This section is made up of mottled silts and clays, typical of a flood plain and paleosol layer.

The next overlying environment (222 to 203) is interpreted as a distal levee/ flood plain. The lithology of this section is a group of interbedded sands and silts. Multiple solid pieces of charcoal are found in this layer, possibly the recovered sections of in larger pieces that had been deposited on the flood plain.

The distal levee/ flood plain sediments underlie a layer weathered flood plain and paleosol sediments (from 203 to $183 \mathrm{ft}$ ). Mottling and laminations of clay are present throughout this section. Any sandy zones also contain a high percentage of clay and silt. 
A thin sand bed is at the top section (183 to $177 \mathrm{ft}$ ), indicating a transition to a crevasse splay/ proximal levee environment. There is abundant charcoal in this layer and overall grain size fines upward, typical in this type of environment.

This thin sand bed underlies an interlaminated sands and silts layer interpreted as a distal levee/ flood plain environment. The lithology alternates between sands and clay, with the sands being infiltrated with fines. At the top $(160 \mathrm{ft})$ and the base $(177$ $\mathrm{ft}$ ) of this section are clay beds that encompass the silts and sands.

A thick sand, deposited by an isolated river channel, overlies the distal levee/ flood plain deposits. Large portions of this section were unable to be recovered. This $20 \mathrm{ft}$ section would indicate that the river had migrated over top of the previous distal levee/ flood plain.

A very heterolithic layer of sand and clay from 139.1 to $122.8 \mathrm{ft}$ overlies the thick sand deposit. This heterolithic layer is difficult to assign to one of the five determined lithofacies. This layer gives way to an interlaminated sands and silts package (75 to $122 \mathrm{ft}$ ), interpreted as a distal levee/ flood plain.

Variegated silts and clays from 75 to $65 \mathrm{ft}$ are interpreted as a weathered flood plain with paleosols layer. The lithology is a mottled clay layer with hematite nodules. These red and brown deposits are interpreted as mature to well-developed soils (Thornburg, 2017).

The weathered flood plain underlies an isolated channel, thick sand, deposit. Some thin beds of clay are found within this thick sand, overall the sand is 
homogeneous. The channel river channel has at this point migrated over the flood plain, to this location, depositing this thick sand package.

The thick sand package underlies another section of interlaminated sands and silts. This interlaminated sand and silt package is interpreted as a distal levee/ flood plain environment of deposition. This is likely the result of the river gradually migrating away from this location. The environment of deposition above this section, weathered flood plain and paleosols, also supports the theory of the channel migrating farther from this location.

\section{Dc53-07 Delaware City}

No core was taken for this borehole, therefore interpretations are based solely on geophysical logs. The logs and interpretations can be found in Figure 3.4. Potomac unit $\mathrm{C}$ is heterogenous, showing frequent spikes in resistivity and gamma on the geophysical logs. This section, from 770 to $440 \mathrm{ft}$, alternates from sand to mud in roughly $30 \mathrm{ft}$ intervals at the top of the unit, and in about $10 \mathrm{ft}$ intervals towards the base of the unit. This rapid transitioning is likely indicative of an unstable environment of deposition, something that was changing rapidly or greatly affected by large scale events. These are likely overbank deposits from short lived flooding events. These events would have deposited small intervals of sand, then the environment would return to floodplain for long periods of time.

The interpretations of Potomac A (300 to $90 \mathrm{ft}$ ) and Potomac B (440 to $300 \mathrm{ft}$ ) are dominated by thick layers of mud which are interpreted as flood plain deposits. At 
the base of Potomac A is a thicker sand package. Based on the geophysical logs it doesn't appear to be a clean sand. Frequent drops in resistivity within the interpreted sand package indicate infiltration by muds.

\section{Ec14-01 Delaware City}

This interpretations for this borehole are also based solely on geophysical logs. The logs and lithologic interpretations are shown in Figure 3.5. The logs indicate that the majority of this borehole is very heterogenous. A thick sand package (about $50 \mathrm{ft}$ thick) at the top of Potomac C (360 ft) and a second (about $100 \mathrm{ft}$ thick) sand package at the base of Potomac $\mathrm{C}$ are the most notable sand packages, likely from a crevasse splay or proximal levee environment, in the borehole. From the top of Potomac A (105 $\mathrm{ft})$ to the base of this borehole $(750 \mathrm{ft})$, the overall trend appears to be an increase in the net amount of total sand deeper in the borehole. This could be due to the river channel being located in this location when the sediments towards the base were being deposited. Over time the river system migrated away from this location, but it did not go far and repeatedly returned to this area.

\section{Fort Mott}

The Fort Mott borehole interpretations are based on onsite observations from the Sugarman, et al. (2007) International Ocean Drilling Program report. Data for this bore hole is displayed in Figure 3.6. This borehole is dominated by silt and clay throughout the majority of the section. From 820 to 720 are three silt dominated layers 
transitioning from silt with sand, to silt with clay, and back to silt with sand. This section was likely deposited in a distal levee/ flood plain environment. The next section above, from 720 to $660 \mathrm{ft}$, is a layer of clay, underlying a layer silt and clay from 660 to $600 \mathrm{ft}$. This indicates a decrease in energy in the environment, likely transitioning to more of a developed floodplain. Sand with lignite overlies this layer from 600 to $560 \mathrm{ft}$. This thick sand layer is interpreted as an isolated channel, still not a very clean aquifer sand. Another thick layer of silt and clay is interpreted at 560 to $420 \mathrm{ft}$. This is indicative of a transition back to a distal levee/ floodplain environment of deposition. The borehole continues to fine upwards into a bed of clay from 420 to $365 \mathrm{ft}$. This is interpreted as a floodplain deposit.

In the middle of Potomac A at 365 to $285 \mathrm{ft}$ is a sand package that is bordered and infiltrated with clay and silt. This thick sand deposit is interpreted as an isolated channel deposit; however, it is very heterogenous indicating frequent changes in the environment. The uppermost section of the Potomac Formation from this borehole is from 285 to $141 \mathrm{ft}$ is thick silt and clay deposit, interpreted as a distal levee/ floodplain deposit.

\section{Summit Marina}

Lithologic interpretations and geophysical logs can be found on Figure 3.7.

The base of the Potomac Formation in the Summit Marina borehole is a $100 \mathrm{ft}$ thick section of interlaminated silts, clays, and thin sand beds (500 to $400 \mathrm{ft}$ ). This underlies a variegated silts and clays bed (390 to $341 \mathrm{ft}$ ) with thin beds of 
interlaminated sands and silts on below (400 to $390 \mathrm{ft}$ ) and on top of it (341 to $333 \mathrm{ft}$ ). All of these layers are representative of a low energy environment, possibly flood plain and distal levee deposits.

This underlies a roughly $100 \mathrm{ft}$ thick amalgamated sand package. The sand coarsens upwards. The interpreted environment of deposition is an amalgamated channel. This depositional environment is recognized in the blocky patterns of the geophysical logs. This sand gives way to a layer of variegated silts and clays from 223 to $155 \mathrm{ft}$, indicating a transition to a weathered flood plain and paleosols environment. This layer underlies a thick sand package at 155 to $141 \mathrm{ft}$, interpreted as an isolated channel environment. This shallowest sand package has potential to be a local aquifer. The upper most section of the Potomac in this location is made up of a thin layer of interlaminated sands and silts and a thin layer of variegated silts and clays. This sequence of layers would indicate the channel has shifted farther away from this location over time.

\section{Cd51-21 New Castle}

Lithologic interpretations and geophysical logs can be found in Figure 3.8.

The base of the Potomac Formation in this borehole is made up of variegated silts and clays with interlaminated thin sands. This is section from 420 to $298 \mathrm{ft}$ is interpreted as a weathered flood plain and paleosol environment of deposition with thin crevasse splay/ proximal levee deposits. This layer underlies a thick amalgamated 
sand package that coarsens upwards from 298 to 200. This is indicative of an amalgamated channel.

The next higher interval (200 to 115 ) is predominantly silts and clays that are interpreted as flood plain deposits. These flood plain deposits underlie another amalgamated sand package at 115 to $75 \mathrm{ft}$. This would indicate that a river channel migrated away from this location, flood plain deposits were left, and then migrated back and left the amalgamated sands. Interlaminated sands and silts overlie this deposit flowed by a thin sand at 75 to $35 \mathrm{ft}$. These deposits are representative of distal levee/ flood plain deposits with crevasse splay/ proximal levee deposits between. The uppermost Potomac Formation is from 35 to $15 \mathrm{ft}$, made up of variegated silts and clays. These are interpreted as weathered floodplain/ paleosol deposits.

\section{Cd51-23 New Castle}

Lithologic interpretations and geophysical logs can be found in Figure 3.9.

The base of the Potomac Formation in this borehole (442 ft) is composed of a roughly $170 \mathrm{ft}$ thick variegated silts and clays with sandy zones. This is interpreted as being deposited in a weathered flood plain and paleosols environment. This underlies a section of thick sands with interlaminated sand and silt sections from 263 to $195 \mathrm{ft}$. This is interpreted as an isolated channel deposit with periods of deposition in a crevasse splay/ proximal levee environment.

Variegated silts and clays and interlaminated sands and silts are the next deposits moving up in the core at 195 to $116 \mathrm{ft}$. These deposits are indicative of a 
lower energy environment, either weathered flood plain and paleosols or distal levee environments.

The uppermost section of the Potomac Formation in this location (116 to 60 ft.) is composed of variegated silts and clays. These deposits would indicate that the river channel has left this location for the duration of this section's deposition. These sediments are interpreted as weathered flood plain and paleosol deposits.

\subsection{Cross Section Interpretations:}

\subsubsection{Overall Lithologic Trends}

The overall lithologic trend is that that the Potomac Formation is

heterogeneous throughout this study area. Silts and clays are the dominant lithologies in both the shallow and deep portions of the Potomac Formation, with thinner sand packages throughout. There is fluctuation between boreholes, even on a small scale. Sand packages do not appear to be laterally continuous or regular in their distribution.

All three units within the Potomac Formation follow the similar trends in thickness down dip. As the formation thickens down dip, each unit stays a similar thickness, the exception being Potomac Unit C. Although the other units do increase in thickness, they do not increase at the rate of Potomac C. This is a result of the onlapping of sediments on basement rock. Sediments were deposited the thickest downdip and accumulated over time. The oldest Potomac $\mathrm{C}$ sediments were not deposited in the northeast, evident by the lack of older palynomorph zones. In the southwest of this study area Zone I palynomorphs were identified in the boreholes 
where Potomac C was the thickest. Potomac B and Potomac A were deposited over top of Potomac C, which had already created a less variable topographic surface for sediments to accumulate, explaining the consistency in thickness of those two units.

\subsubsection{Palynological Trends}

The correlation of the palynological data allowed for more accurate stratigraphic interpretations to be made. The palynomorph zonations (Doyle and Robbins, 1977) gave greater insight into the development of the formation and the ages of the sediments. These previous studies interpreted a wide range of pollen zones.

The lithologic units showed a strong correlation to the palynomorph zonations. Palynological Zone I and Zone II-A were consistently interpreted at the base of Potomac C. Palynological Zone II-B was consistently interpreted at the contact (or slightly above or below it) of the base of Potomac B. Palynological Zone II-C was present throughout Potomac B, and Zone III was present throughout Potomac A.

Horizons for the three units of the Potomac Formation had to be interpreted for Bear/Christiana and Prest Property new for this study. Bear/Christiana was interpreted as being all Potomac B sediments, based on the presence of Zone II-B palynomorphs at the top of the formation. Zone II-B palynomorphs were interpreted in Prest Property as well. These palynomorphs indicated the contact between Potomac C and B.

The palynomorphs of this study contained a narrow range of the overall pollen assemblage of the Potomac Formation. All of the new palynomorphs observed for this 
study were Zone II-B, with no representation of any of the other stratigraphically important zonations.

Due to this strong correlation, previous interpreted boreholes should be revisited with use of biostratigraphic data.

\subsubsection{Palynofacies and Environments}

The palynomorphs of the three boreholes processed in this study give an insight into the evolution of angiosperms and the environments of the Potomac Formation.

The palynomorphs were sorted into seven groups based upon morphological characteristics to understand the environmental trends in vegetation. These groups were eudicots, magnoliids/monocots, Classopollis, Araucariacites, bisaccate, inaperturate, and pteridophyte spores.

Palynomorph abundances are also used to interpret the landscape.

Paleoenvironmental interpretations made using palynomorphs are based strongly on the moisture and temperature implications that can be made from those species' types (Mongrain et al. 2015). The majority of work on Cretaceous palynomorphs has been focused on angiosperm pollen found in Europe. The results of these studies have been compared to palynomorph assemblages from the Middle Atlantic (Heimhofer et al. 2005, Horikx et al. 2017) and the two regions share many similarities. 
The palynomorphs identified in this study were all determined to be middle to late Albian in age. From the early Albian to the Cenomanian, a steady temperature rise was occurring where a relatively stable sub arid to sub humid climate was transitioning to a semi-arid one, based on palynomorphs samples from Portugal (Horikx et al., 2016). Angiosperms quickly became abundant in this time and were highly productive, becoming a source of fires during the Cretaceous. Angiosperms were then capable of spreading throughout these frequently disturbed areas (Bond and Scott, 2012). This increase in abundance also brought upon diversification (Coiffard et al. 2012). The Albian shows the first occurrences of angiosperms transitioning from being solely aquatic and riparian, to living in floodplains (Coiffard, 2017).

In the Bear/Christiana borehole (table 1) eudicots and magnoliids/monocots show a slight increase moving upwards. This could be the result of continued temperature increase and the spread of angiosperm pollen across more environments. Inaperturate pollen and pteridophyte spores are the dominant morphological types found in this location. The lithologic interpretation of the environments of deposition tend to agree with the palynomorphs. Both data sets could be indicating a floodplain environment, with fluvial influences. However, there is a possibility for lithologic bias with only dark gray muds being chosen for palynomorph processing. These muds are commonly interpreted as floodplain deposits.

In the Prest Property borehole (table 2) many of the same interpretations as the Bear/Christiana borehole can be made. Overall increases in angiosperm pollen are seen from the lowest interval to top, possibly indicating an increase in the angiosperm 
population. A spike in eudicot pollen is seen at the contact between lithologic zone Potomac B and Potomac C. Inaperturate pollen and pteridophyte spores are the most abundant morphological types. These indicate the same general environmental interpretations as Bear/Christiana, floodplain with fluvial influences. The same lithologic bias applies to this borehole, since dark gray muds were targeted for palynomorph processing.

The Glasgow borehole (table 3) saw many of the same trends as the previous two boreholes discussed. Eudicot and magnoliid/monocot pollen both increase upwards in section, and inaperturate pollen and pteridophyte spore are the dominate types. In this borehole, bisaccate pollen also increase upwards. This could be indicative of a somewhat dryer climate, indicated by the presence of the bisaccate conifer pollen. Overall, most of the interpretations can be made of palynological environment; floodplain with some fluvial influences, possibly not as strong as the other two sites. The lithologic interpretations agree with interpretation, again the lithologic bias must be taken into consideration. 


\section{Chapter 5}

\section{CONCLUSION}

This study of the Cretaceous aged Potomac Formation in New Castle County, Delaware has yielded important information regarding the subsurface stratigraphy of northern Delaware and the trends in distribution of different lithologies of this complex formation. Through examining sediment core, geophysical logs, and palynomorphs from the Potomac Formation, a greater understanding of the age and paleoenvironment was able to be made through the nine boreholes being used in the study.

The three boreholes examined new for this study (Bear/Christiana, Prest Property, and Glasgow) all show non-marine alluvial plain deposits interpreted within the Potomac Formation. The overall trend in lithofacies is a weathered floodplain/ paleosol environment of deposition making up the majority of deposits. About $50 \%$ of the deposits were paleosols, $25 \%$ of the deposits fluvial sands, and $25 \%$ distal levee or wet floodplain deposits. These deposits are composed of muds, silts and clays, with intermittent fine sands. Deeper in the Potomac Formation, the overall amount of sand was greater than shallower units within the formation. Potomac $\mathrm{C}$ contains more thick beds of aquifer quality sands than the shallower two units.

Using data from six boreholes that had been obtained for previous studies, coupled with the new data from the three boreholes mentioned earlier, a regional correlation was conducted within the Potomac Formation. All nine boreholes were in 
New Castle County, Delaware and were capable of showing trends in three directions; northern, southern, and down dip of the Atlantic Coastal Plain. The regional trend was that the Potomac Formation thickens and becomes deeper down dip to the south east with the units onlapping one another. This trend coincides with the basement of the Atlantic Coastal Plain. On strike, the units of the Potomac Formation maintain a generally horizontal trend.

The three new boreholes were examined for palynological data to obtain a more accurate correlation. In total, 26 samples were analyzed for palynomorph assemblages. Samples were chosen based depth and sediments ability to preserve palynomorphs. It was determined that each of the three boreholes contain only Zone II-B palynomorphs, which is interpreted as middle to late Albian in age.

The angiosperm pollen generally increases in abundance and diversity moving up in the boreholes. This supports the theory that as angiosperms developed they were capable of inhabiting a wide range of environments (Doyle, 1969). The overall angiosperm abundances loosely indicated a floodplain type environment. During the Albian, the interpreted age of the angiosperms identified, angiosperms are known to be transitioning to flood plain environments. This supported the lithologic environmental interpretations of weathered flood plain deposits, however there is a strong possibility for lithologic bias.

When combining the lithologic interpretations and the palynological interpretations stratigraphic trends were able to be identified. The Zone II-B palynomorphs, identified new in this study, generally occur at the contact between 
Potomac B and Potomac C. This trend was consistent through all nine boreholes used in this study. The original zonations were also able to be correlated across New Castle County, adding important new data to constrain correlations. The new data has showed how to accurately correlate the units of the Potomac Formation in areas where palynomorph data is not available.

The results of this study help to better understand the stratigraphic trends and depositional history of the heterogenous Potomac Formation. Through this information, more accurate interpretations can be made when attempting to understand aquifer connectivity and distribution in this extremely heterogenous formation. 


\section{REFERENCES}

Benson, R. N., \& McLaughlin Jr, P. P. (2006a). Internal stratigraphic correlation of the subsurface Potomac Formation, New Castle County, Delaware, and adjacent areas in Maryland and New Jersey (No. 71). Newark, DE: Delaware Geological Survey, University of Delaware. Retrieved from http://udspace.udel.edu/handle/19716/2809

Bond, W. J., \& Scott, A. C. (2010). Fire and the spread of flowering plants in the Cretaceous. New Phytologist, 188(4), 1137-1150. https://doi.org/10.1111/j.1469-8137.2010.03418.x

Brenner, G. J. (1963). The spore and pollen of the Potomac Group of Maryland (p. 215). Maryland Dept. Geology, mines, and Mineral Resources.

Clark, W. B., \& Bibbins, A. (1897). The stratigraphy of the Potomac Group in Maryland. The Journal of Geology, 5(5), 479-506.

Coiffard, C., Gomez, B., Daviero-Gomez, V., \& Dilcher, D. L. (2012). Rise to dominance of angiosperm pioneers in European Cretaceous environments. Proceedings of the National Academy of Sciences, 109(51), 20955-20959. https://doi.org/10.1073/pnas.1218633110

Coiffard, C., Gomez, B., \& Thevenard, F. (2007). Early Cretaceous Angiosperm Invasion of Western Europe and Major Environmental Changes. Annals of Botany, 100(3), 545-553. https://doi.org/10.1093/aob/mcm160

Coiffard, C., Gomez, B., \& Daviero-Gomez, V. (2012). Deciphering Early Angiosperm Landscape Ecology Using a Clustering Method on Cretaceous 
Plant Assemblages. In J. Tiefenbacher (Ed.), Perspectives on Nature Conservation - Patterns, Pressures and Prospects. InTech. https://doi.org/10.5772/32125

Doyle, J. A. (1969). Cretaceous angiosperm pollen of the Atlantic Coastal Plain and its evolutionary significance. Journal of the Arnold Arboretum, 50(Number 1), 133.

Doyle, J. A. (1992). Revised palynological correlations of the lower Potomac group (USA) and the cocobeach sequence of Gabon (Barremian-Aptian). Cretaceous Research, 13(4), 337-349. https://doi.org/10.1016/0195-6671(92)90039-S

Doyle, J. A., \& Robbins, E. I. (1977). Angiosperm pollen zonation of the continental Cretaceous of the Atlantic Coastal Plain and its application to deep wells in the Salisbury Embayment. Palynology, 1, 43-78.

Edwards Jr., J., \& Hansen, H. (1979). New data bearing in the structural significance of the upper Chesapeake Bay magnetic anomaly (No. 30). Maryland Geological Survey.

Glaser, J. (1969). Petrology and origin of Potomac and Magothy (Cretaceous) sediments, middle Atlantic Coastal Plain (No. 11). Maryland Geological Survey.

Groot, J. J. (1955a). Sedimentary petrology of the Cretaceous sediments of northern Delaware in relation to paleogeographic problems. Newark, DE: Delaware Geological Survey, University of Delaware. Retrieved from http://udspace.udel.edu/handle/19716/2793 
Groot, J. J. (1955b). Sedimentary petrology of the Cretaceous sediments of northern Delaware in relation to paleogeographic problems. Newark, DE: Delaware Geological Survey, University of Delaware. Retrieved from http://udspace.udel.edu/handle/19716/2793

Hansen, H., \& Doyle, J. A. (1982). Waste Gate Formation. Open File Report, 102. Heimhofer, U., Hochuli, P. A., Burla, S., \& Weissert, H. (2007). New records of Early Cretaceous angiosperm pollen from Portuguese coastal deposits: Implications for the timing of the early angiosperm radiation. Review of Palaeobotany and Palynology, 144(1-2), 39-76. https://doi.org/10.1016/j.revpalbo.2005.09.006

Hochuli, P. A., Heimhofer, U., \& Weissert, H. (2006). Timing of early angiosperm radiation: recalibrating the classical succession. Journal of the Geological Society, 163(4), 587-594.

Hochuli, Peter A., \& Feist-Burkhardt, S. (2013). Angiosperm-like pollen and Afropollis from the Middle Triassic (Anisian) of the Germanic Basin (Northern Switzerland). Frontiers in Plant Science, 4. https://doi.org/10.3389/fpls.2013.00344

Horikx, M., Hochuli, P. A., Feist-Burkhardt, S., \& Heimhofer, U. (2016). Albian angiosperm pollen from shallow marine strata in the Lusitanian Basin, Portugal. Review of Palaeobotany and Palynology, 228, 67-92. https://doi.org/10.1016/j.revpalbo.2015.12.008

Horikx, M., Huck, S., Adatte, T., \& Heimhofer, U. (2017). Vegetation dynamics, angiosperm radiation and climatic changes in the Lusitanian Basin (Portugal) 
during Albian times. Palaeogeography, Palaeoclimatology, Palaeoecology, 465, 30-41. https://doi.org/10.1016/j.palaeo.2016.10.011

Jordan, R. R. (1962). Stratigraphy of the sedimentary rocks of Delaware. Newark, DE: Delaware Geological Survey, University of Delaware. Retrieved from http://udspace.udel.edu/handle/19716/2957

Jordan, R. R. (1983). Stratigraphic Nomenclature Of Nonmarine Cretaceous Rocks Of Inner Margin Of Coastal Plain In Delaware And Adjacent States. Newark, DE: Delaware Geological Survey, University of Delaware. Retrieved from http://udspace.udel.edu/handle/19716/3158

Jud, N. A., \& Hickey, L. J. (2013). Potomacapnos apeleutheron gen. et sp. nov., a new Early Cretaceous angiosperm from the Potomac Group and its implications for the evolution of eudicot leaf architecture. American Journal of Botany, 100(12), 2437-2449. https://doi.org/10.3732/ajb.1300250

Lee, A. P., Upchurch, G., Murchie, E. H., \& Lomax, B. H. (2015). Leaf energy balance modelling as a tool to infer habitat preference in the early angiosperms. Proceedings of the Royal Society B: Biological Sciences, 282(1803), 20143052-20143052. https://doi.org/10.1098/rspb.2014.3052

Makaske, B. (2001). Anastomosing rivers: a review of their classification, origin and sedimentary products. Earth-Science Reviews, 53(3), 149-196.

McKenna, T. E., McLaughlin, P. P., \& Benson, R. N. (2004). Characterization Of The Potomac Aquifer, An Extremely Heterogeneous Fluvial System In The 
Atlantic Coastal Plain Of Delaware. Retrieved from

http://dspace.udel.edu/handle/19716/3247

Mongrain, J. R., Mccarthy, P. J., Plint, A. G., \& Fowell, S. J. (2013). "Integrated

Paleopedology and Palynology from Alluvial Paleosols of the Cretaceous (Cenomanian) Dunvegan Formation, Alberta and British Columbia, Canada:

Paleoenvironmental and Stratigraphic Implications", New Frontiers in

Paleopedology and Terrestrial Paleoclimatology: Paleosols and Soil Surface

Analog Systems, Steven G. Driese, Lee C. Nordt

Stromberg, J. (2013, November 29). This could be the oldest flowering plant ever

found in North America: A new look at the Smithsonian's fossil collection

turned up a remarkably ancient flowering plant- scientist think it's at least 115

million years old. smithsonian.com.

Thornburg, J. (2016). Reconstructing landscapes across the early to late Cretaceous transition - evaluating base level, climate and sequence stratigraphy from Potomac formation sediments in New Jersey and Delaware. Rutgers University.

Wolfe, J. A. and Pakiser, H. M., 1971, Stratigraphic interpretations of some Cretaceous microfossil floras of the Middle Atlantic States: U. S. Geological Survey Professional Paper 750-B, p. B35-B47.

Zullo, C.C., 2012, Seismic imaging and hydrogeologic characterization of the Potomac Formation in Northern New Castle County, Delaware [Ph.D. thesis]: Newark, University of Delaware, 218 p. 
Appendix

SUPPLEMENTAL MAETERIAL 
Table A1:

Location: Glasgow

Depth: $83.5 \mathrm{ft}$

Sample number: 110003-3.5

Stratigraphic interpretation: Subzone II-B

Spores:

Cyathidities minor

Gleicheniidites senonicus

Liliacidites variegatus

Lycopodiacidites irregularis

Neoraistrickia robusta

Peromonolites peroreticulatus

Pilosisporites brevipapillosus

Sphagnumsporites psilatus

Pollen:

Araucariacites australis (cf.)

Circulina parva

Decussosporites microreticulatus

Inaperturopollenites dubius

Podocarpidites potomacensis

Tricolpites crassimurus (aff.)

Tricolpopollenites micromunus

Location: Glasgow

Depth: $89.1 \mathrm{ft}$

Sample number: 110004-4.1

Stratigraphic interpretation: Subzone II-B

Spores:

Cyathidities minor

Gleicheniidites senonicus

Pollen:

Araucariacites australis (cf.)

Clavatipollenites minutus

Inaperturopollenites dubius

Monosulcites epakros 
Monosulcites minimus

Podocarpidites epistratus

Podocarpidites potomacensis

Tricolpopollenites micromunus

Location: Glasgow

Depth: $95.1 \mathrm{ft}$

Sample number: 110005-5.1

Stratigraphic interpretation: Subzone II-B

Spores:

Cicatricosisporites hallei

Gleicheniidites senonicus

Peromonolites allenensis

Pollen:

Circulina parva

Clavatipollenites minutus

Decussosporites microreticulatus

Inaperturopollenites dubius

Monosulcites epakros

Monosulcites minimus

Parvisaccites amplus

Parvisaccites rugulatus

Podocarpidites epistratus

Podocarpidites potomacensis

Spheripollenites perinatus

Location: Glasgow

Depth: $100.9 \mathrm{ft}$

Sample number: 110006-0.9

Stratigraphic interpretation: Subzone II-B

Spores:

Cyathidities minor

Pollen:

Circulina parva

Clavatipollenites minutus 
Inaperturopollenites dubius

Monosulcites epakros

Monosulcites minimus

Parvisaccites radiatus

Phyllocladidites microreticulatus

Retitricolpites virgeus

Spheripollenites perinatus

Tricolpites albiensis (cf.)

Tricolpites crassimurus (aff.)

Tricolpites minutus

Location: Glasgow

Depth: $110.7 \mathrm{ft}$

Sample number: 110007-0.7

Stratigraphic interpretation: Subzone II-B

Spores:

Cyathidities minor

Gleicheniidites senonicus

Pollen:

Clavatipollenites minutus

Inaperturopollenites dubius

Monosulcites epakros

Monosulcites glottus

Parvisaccites amplus

Retitricolpites fragosus (cf.)

Tricolpites albiensis (cf.)

Tricolpopollenites micromunus

Vitreisporites pallidus

Location: Glasgow

Depth: $117.5 \mathrm{ft}$

Sample number: 110007-7.5

Stratigraphic interpretation: Subzone II-B

Spores:

Pollen:

Araucariacites australis (cf.)

Circulina parva 
Clavatipollenites minutus

Entylissa nitidus

Inaperturopollenites dubius

Liliacidites dividuus

Monosulcites minimus

Parvisaccites amplus

Podocarpidites epistratus

Tricolpites micromunus (cf.)

Vitreisporites pallidus

Location: Glasgow

Depth: $120.2 \mathrm{ft}$

Sample number: 110008-0.2

Stratigraphic interpretation: Subzone II-B

Spores:

Appendicisporites dentimarginatus

Ceratosporites parvus

Peromonolites allenensis

Todisporites minor

Pollen:

Alisporites bilateralis (cf.)

Araucariacites australis

Eucommiidites troedssonii

Inaperturopollenites dubius

Parvisaccites amplus

Spheripollenites perinatus

Tricolpites micromunus (cf.)

Tricolpopollenites minutus

Location: Glasgow

Depth: $161.8 \mathrm{ft}$

Sample number: 110014-1.8

Stratigraphic interpretation: Subzone II-B

Spores:

Cicatricosisporites australiensis

Cyathidities minor

Peromonolites allenensis

Todosporites minor 
Pollen:

Circulina parva

Clavatipollenites minutus

Inaperturopollenites dubius

Retitricolpites prosimilis

Striatopollis sp. A

Tricolpites micromunus (cf.)

Tricolpopollenites crassimurus

Location: Glasgow

Depth: $165.6 \mathrm{ft}$

Sample number: 110014-5.6

Stratigraphic interpretation: Subzone II-B

Spores:

Cicatricosisporites austrailiensis

Cyathidites minor

Gleicheniidites senonicus

Pollen:

Circulina parva

Clavatipollenites minutus

Inaperturopollenites dubius

Liliacidites dividuus

Monosulcites minimus

Tricolpites micromunus (cf.)

Tricolpopollenites parvulus (cf.)

Location: Glasgow

Depth: $183 \mathrm{ft}$

Sample number: 110016-3

Stratigraphic interpretation: Subzone II-B

Spores:

Pollen:

Circulina parva

Clavatipollenites minutus

Inaperturopollenites dubius

Monosulcites epakros

Monosulcites minimus 
Peromonolites allenensis

Speripollenites perinatus

Tricolpites micromunus (cf.)

Tricolpopollenites minutus

Tricolpopollenites parvulus

(cf.)

Location: Glasgow

Depth: $210.9 \mathrm{ft}$

Sample number: 110019-0.9

Stratigraphic interpretation: Subzone II-B

Spores:

Pollen:

Asteropollis asteroides (cf.)

Circulina parva

Clavatipollenites minutus

Inaperturopollenites dubius

Monosulcites epakros

Monosulcites glottus

Penetetrapites mollis

Podocarpidites potomacensis

Retitricolpites fragosus (cf.)

Retitricolpites virgeus

Tricolpites crassimurus (aff.)

Tricolpites micromunus (cf.)

Tricolpopollenites minutus

Tricolpopollenites parvulus

(cf.)

Location: Bear/Christiana

Depth: $36.3 \mathrm{ft}$

Sample number: 116380-1.3

Stratigraphic interpretation: Subzone II-B

Spores:

Alisporites bilateralis (cf.)

Peromonolites allenensis 
Pollen:

Clavatipollenites minutus

Retitricolpites fragosus (aff.)

Tricolpites albiensis (aff.)

Tricolpopollenites parvulus (cf.)

Location: Bear/Christiana

Depth: $46.1 \mathrm{ft}$

Sample number: 116382-1.1

Stratigraphic interpretation: Subzone II-B

Spores:

Alisporites minutus

Cicatricosisporites hallei

Laevigatosporites gracilis

Pollen:

Clavatipollenites minutus

Inaperturopollenites dubius

Monosulcites epakros

Monosulcites minimus

Retitricolpites prosimilis

Tricolpites albiensis (cf.)

Tricolpopollenites

micromunus

Tricolpopollenites minutus

Location: Bear/Christiana

Depth: $51.55 \mathrm{ft}$

Sample number: 116382-6.55

Stratigraphic interpretation: Subzone II-B

Spores:

Cyathidites minor

Gleicheniidites senonicus

Pollen:

Clavatipollenites minutus 
Inaperturopollenites dubius

Monosulcites minimus

Peromonolites allensis

Podocarpidites sp. sp.

Retitricopites fragosus (aff.)

Spheripollenites perinatus

Tricolpites albiensis (aff.)

Tricolpopollenites micromunus

Location: Bear/Christiana

Depth: $66.4 \mathrm{ft}$

Sample number: 116384-1.4

Stratigraphic interpretation: Subzone II-B

Spores:

Gleicheniidites circiidites

Gleicheniidites senonicus

Laevigatosporites gracilis

Pollen:

Cicatricosisporites

annulatus

Clavatipollenites minutus

Entylissa nitidus

Monosulcites minimus

Parvisaccites amplus

Podocarpidites

potomacensis

Podocarpidites sp. sp.

Retitricolpites fragosus

(aff.)

Tricolpopollenites minutus

Location: Bear/Christiana

Depth: $75.6 \mathrm{ft}$

Sample number: 116385-0.6

Stratigraphic interpretation: Subzone II-B

Spores:

Cicatricosisporites potomacensis 
Peromonolites allenensis

Vitreisporites pallidus

Pollen:

Circulina parva

Clavatipollenites minutus

Entylissa nitidus

Inaperturopollenites dubius

Monosulcites chaloneri

Monosulcites epakros

Tricolpites albiensis (cf.)

Tricolpites micromunus (cf.)

Tricolpopollenites pumilis

Location: Bear/Christiana

Depth: $86 \mathrm{ft}$

Sample number: 116386-1

Stratigraphic interpretation: Subzone II-B

Spores:

Cyathidites minor

Deltoidospora hallii

Tsugaepollenites mesozoicus

Pollen:

Clavatipollenites minutus

Entylissa nitidus

Inaperturopollenites dubius

Monosulcites minumus

Podocarpidites potomacensis

Striatopollis sp. sp. A

Tricolpites albiensis (cf.)

Tricolpites micromunus (cf.)

Tricolpopollenites micromunus

Tricolpopollenites minutus

Tricolpopollenites parvulus (aff.)

Location: Prest Property

Depth: $307.2 \mathrm{ft}$

Sample number: 115129-7.2

Stratigraphic interpretation: Subzone II-B 
Spores:

Cicatricosisporites dorogenesis

Laevigatosporites gracilis

Tsugaepollenites mesozoicus

Pollen:

Circulina parva

Inaperturopollenites dubius

Podocarpidites potomacensis

Retimonocolpites dividuus (cf.)

Retitricolpites magnificus (cf.)

Tricolpites micromunus (cf.)

Tricolpites albiensis (cf.)

Tricolpopollenites minutus

Location: Prest Property

Depth: $316.8 \mathrm{ft}$

Sample number: 115130-6.8

Stratigraphic interpretation: Subzone II-B

Spores:

Appendicisporites tricornitatus

Cyathidites minor

Gleicheniidites senonicus

Neoraistrickia robusta

Psilatriletes circumundulatus

Pollen:

Circulina parva

Clavatipollenites minutus

Inaperturopollenites dubius

Monosulcites epakros

Tricolpites albiensis (aff.)

Tricolpites micromunus (cf.)

Tricolpopollenites parvulus (cf.)

Location: Prest Property

Depth: $333.6 \mathrm{ft}$

Sample number: 115132-3.6

Stratigraphic interpretation: Subzone II-B 
Spores:

Alisporites bilateralis (cf.)

Decussosporites microreticulatus

Laevigatosporites gracilis

Peromonolites allenensis

Tsugaepollenites mesozoicus

Pollen:

Clavatipollenites minutus

Inaperturopollenites dubius

Parvisaccites amplus

Spheripollenites perinatus

Tricolpites albiensis (aff.)

Tricolpites micromunus (cf.)

Tricolpopollenites minutus

Tricolpopollenites parvulus (cf.)

Location: Prest Property

Depth: $354.3 \mathrm{ft}$

Sample number: 115134-4.3

Stratigraphic interpretation: Subzone II-B

Spores:

Cicatricosisporites potomacensis

Laevigatosporites gracilis

Peromonolites allensis

Tsugaepollenites mesozoicus

Pollen:

Circulina parva

Clavatipollenites minutus

Inaperturopollenites dubius

Monosulcites epakros

Monosulcites minimus

Podocarpidites epistratus

Tricolpites albiensis (aff.)

Tricolpopollenites minutus

Location: Prest Property

Depth: $373.4 \mathrm{ft}$

Sample number: 115136-3.4 
Stratigraphic interpretation: Subzone II-B

Spores:

Cingulatisporites caminus

Tsugaepollenites mesozoicus

Pollen:

Clavatipollenites minutus

Inaperturopollenites dubius

Monosulcites epakros

Monosulcites minimus

Retitricolpites magnificus

(cf.)

Location: Prest Property

Depth: $382.85 \mathrm{ft}$

Sample number: 115137-5.35

Stratigraphic interpretation: Subzone II-B

Spores:

Allisporites bilateralis (cf.)

Decussosporites microreticulatus

Pollen:

Circulina parva

Clavatipollenites minutus

Eucommiidites troedssonii

Inaperturopollenites dubius

Peromonolites allenensis

Spheripollenites perinatus

Tricolpites micromunus (aff.)

Location: Prest Property

Depth: $395.4 \mathrm{ft}$

Sample number: 115140-0.4

Stratigraphic interpretation: Subzone II-B

Spores:

Alsophilidites pannuceus

Cicatricosisporites potomacensis

Cyathidites minor

Tsugaepollenites mesozoicus 
Pollen:

Circulina parva

Clavatipollenites minutus

Inaperturopollenites dubius

Liliacidites dividuus

Monosulcites epakros

Monosulcites minumus

Pavisaccites amplus

Retitricolpites fragosus (aff.)

Tricolpites albiensis (aff.)

Tricolpopollenites minutus

Location: Prest Property

Depth: $411.6 \mathrm{ft}$

Sample number: 115141-6.6

Stratigraphic interpretation: Subzone II-B

Spores:

Alisporites bilateralis ( $c f$ ).

Todisporites minor

Pollen:

Araucariacites australis

Circulina parva

Clavatipollenites minutus

Inaperturopollenites dubius

Tricolpites crassimurus

Location: Prest Property

Depth: $501.9 \mathrm{ft}$

Sample number: 115150-6.9

Stratigraphic interpretation: Subzone II-B

Spores:

Cingulatisporites reticingulus

Cirratririadites spinulosus

Cyathidites minor

Gleicheniidites senonicus

Microreticulatisporites crassiexinous 
Vitreisporites pallidus

Pollen:

Circulina parva

Cirratririadites spinulosus

Clavatipollenites minutus

Cyathidites minor

Gleicheniidites senonicus

Inaperturopollenites dubius

Microreticulatisporites crassiexinous

Monosulcites epakros

Monosulcites glottus

Monsulcites scabrus

Podocarpidites potomacensis

Todisporites minor

Tricolpites albiensis (aff.)

Tricolpites crassimurus (cf.)

Tricolpites minutus 